GA-A15298

UC-77

\title{
THE GENERAL ATOMIC REPROCESSING PILOT PLANT: ENGINEERING-SCALE DISSOLUTION SYSTEM DESCRIPTION
}

\author{
by \\ H. H. YIP
}

Prepared under

Contract EY-76-C-03-0167

Project Agreement No. 53

for the San Francisco Operations Office

Department of Energy

DATE PUBLISHED: APRIL 1979 


\title{
NOTICE
}

This report was prepared as an account of work sponsored by the United States Government. Neither the United States nor the United States Department of Energy, nor any of their employees, nor any of their contractors, subcontractors, or their employees, makes any warranty, express or implied, or assumes any legal liability or responsibility for the accuracy, completeness or usefulness of any information, apparatus, product or process disclosed, or represents that its use would not infringe privately owned rights.

\author{
Printed in the United States of America \\ Available from \\ National Technical Information Service \\ U.S. Department of Commerce \\ 5285 Port Royal Road \\ Springfield, Virginia 22161 \\ Price: Printed Copy $\$ 5.25$; Microfiche $\$ 3.00$ \\ C. 010
}




\section{DISCLAIMER}

This report was prepared as an account of work sponsored by an agency of the United States Government. Neither the United States Government nor any agency Thereof, nor any of their employees, makes any warranty, express or implied, or assumes any legal liability or responsibility for the accuracy, completeness, or usefulness of any information, apparatus, product, or process disclosed, or represents that its use would not infringe privately owned rights. Reference herein to any specific commercial product, process, or service by trade name, trademark, manufacturer, or otherwise does not necessarily constitute or imply its endorsement, recommendation, or favoring by the United States Government or any agency thereof. The views and opinions of authors expressed herein do not necessarily state or reflect those of the United States Government or any agency thereof. 


\section{DISCLAIMER}

Portions of this document may be illegible in electronic image products. Images are produced from the best available original document. 
GA-A15298

UC-77

\title{
THE GENERAL ATOMIC REPROCESSING PILOT PLANT: ENGINEERING-SCALE DISSOLUTION SYSTEM DESCRIPTION
}

\author{
by \\ H. H. YIP \\ Prepared under \\ Contract EY-76-C-03-0167 \\ Project Agreement No. 53 \\ for the San Francisco Operations Office \\ Department of Energy
}

GENERAL ATOMIC PROJECT 3261

DATE PUBLISHED: APRIL 1979

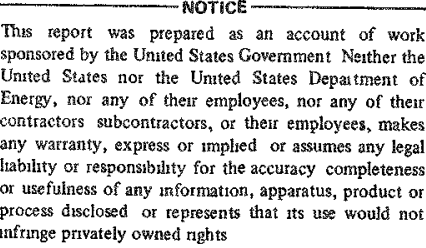

\section{GENERAL ATOMIC COMPANY}


-

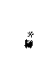

t 


\begin{abstract}
In February 1978, a dissolver-centrifuge system was added to the cold reprocessing pilot plant at General Atomic Company, which completed the installation of an HTGR fuel head-end reprocessing pilot plant. This report describes the engineering-scale equipment in the pilot plant and summarizes the design features derived from development work performed in the last few years. The dissolver operating cycles for both thorium containing BISO and uranium containing WAR fissile fuels are included. A continuous vertical centrifuge is used to clarify the resultant dissolver product solution. Process instrumentation and controls for the system reflect design philosophy suitable for remote operation.
\end{abstract}




\begin{abstract}
. . . . . . . . . . . . . . . . . . . . .
1. INTRODUCTION .......................... . . . . . .

References . . . . . . . . . . . . . . 1-5

2. HEAD-END REPROCESSING FLOW SHEET . . . . . . . . . . . . 2-1

3. DISSOLVER-CENTRIFUGE SYSTEM . . . . . . . . . . . . . . $3-1$

3.1. Dissolver . . . . . . . . . . . . . . 3-1

3.1.1. Dissolver Vesse1 . . . . . . . . . 3-1

3.1.2. Product Removal . . . . . . . . . 3-6

3.1.3. Dissolver Solids Feed . . . . . . . . 3-6

3.1.4. Instrumentation . . . . . . . . . . 3-6

3.1.5. Operating Cycle ............. 3-9

3.2. Condenser ................. 3-12

3.3. Solids Feed Bunkers ................ 3-12

3.4. Centrifuge ............... 3-12

3.5. Repulp Tank ............... 3-18

3.6. Chemicals Makeup and Product Storage Tanks . . . . . 3-18

3.7. Process Instrumentation and Control . . . . . . . . . 3-22

APPENDIX A: PROCESS FLOW DIAGRAMS AND PIPING AND INSTRUMENTATION DRAWINGS ............... . . A-1

APPENDIX B: MAJOR ASSEMBLY DRAWINGS . . . . . . . . . . B B-1
\end{abstract}

\title{
FIGURES
}

1-1. HTGR fuel element................ . . . 1-2

1-2. HTGR coated fuel particles ............ 1-3

1-3. HTGR reprocessing cold pilot plant arrangement . . . . . 1-4

2-1. Cold head-end layout . . . . . . . . . . . . 2-2

3-1. $0.5-m$ dissolver-centrifuge system arrangement . . . . . . 3-2

3-2. Dissolver-centrifuge system (looking south) showing dissolver without insulation ................ 3-3 
FIGURES (Continued)

3-3. Dissolver-centrifuge system viewed from upper deck . . . 3-4

3-4. Dissolver cross section . . . . . . . . . . . 3-5

3-5. Submerged steam jet for slurry transfer from dissolver to centrifuge ................. . . . 3-7

3-6. Dissolver top penetration . . . . . . . . . . . 3-8

3-7. WAR fissile dissolver feed and residue . . . . . . . 3-11

3-8. Sharples Model P-850 vertical centrifuge as installed on upper deck .................. 3-14

3-9. Cross section of Sharples Mode1 P-850 vertical centrifuge . 3-15

3-10. Operation of a continuous vertical centrifuge . . . . . 3-17

3-11. Vertical continuous centrifuge solids discharge . . . . . 3-19

3-12. Centrifuge lubrication system . . . . . . . . . . . 3-20

3-13. Repulp vesse1 being lifted into position for coupling with centrifuge ............... . . 3-21

3-14. Instrumentation and control panels for dissolver-centrifuge system .................. 3-23

3-15. Control cabinets inside central control room . . . . . 3-24

3-16. Control cabinet slope-face control layout . . . . . . 3-25 


\section{INTRODUCTION}

The fuel for a high-temperature gas-cooled reactor (HTGR) consists of small coated particles embedded in fuel elements made from graphite, which acts as a neutron moderator (Fig, 1-1). The reactor utilizes thorium by converting it to $\mathrm{U}-233$. Thorium can be incorporated into the fuel in a number of ways. To optimize the thorium-uranium fuel cycle, a system of separate fuel particles has evolved. The two types of particles used are characterized by the coatings applied to them (Fig. 1-2): BISO particles are coated with a relatively porous buffer layer of carbon and then with a dense coating of pyrolytic carbon; TRISO coatings have a silicon carbide ( $\mathrm{SiC}$ ) coating placed between two layers of pyrolytic carbon. The SiC layer provides a means of separating the TRISO particles from the BISO particles in head-end reprocessing operations, and it enhances fission product retention in the fissile particles. BISO coatings are used for particles which are initially loaded only with thorium oxide; TRISO coatings are used for particles loaded with uranium. After irradiation, the BISO fertile particles contain quantities of U-233. Separation of the fertile particles from the fissile TRISO particles and subsequent recovery of the bred U-233 for use in refabricated fuel is an indispensable part of the recycle of HTGR fuel. The development and demonstration of this recycle technology is the goal of the Department of Energy (DOE) funded National HTGR Fuel Recycle Development Program.

In June 1976, General Atomic Company (GA) completed the construction of a cold engineering-scale dry head-end pilot plant (Fig. 1-3). By February 1978, a dissolver-centrifuge system was added, thereby completing the installation of an HTGR fuel head-end reprocessing pilot plant. The purpose of the plant is to demonstrate the feasibility of the technology on an acceptable scale. The dissolver-centrifuge system has subsequently completed initial design verification testing. 


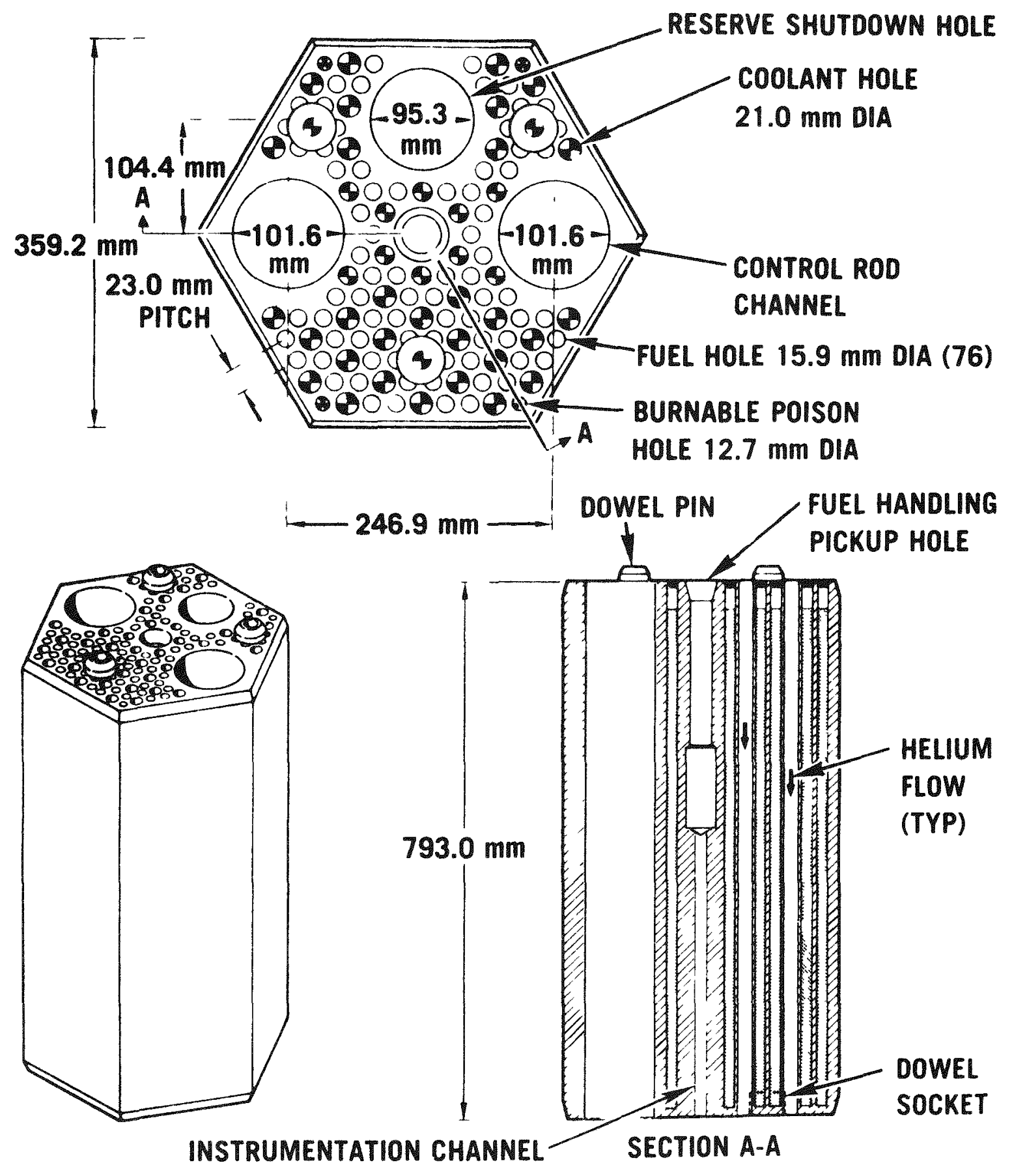

Fig. 1-1, HTGR fuel element 


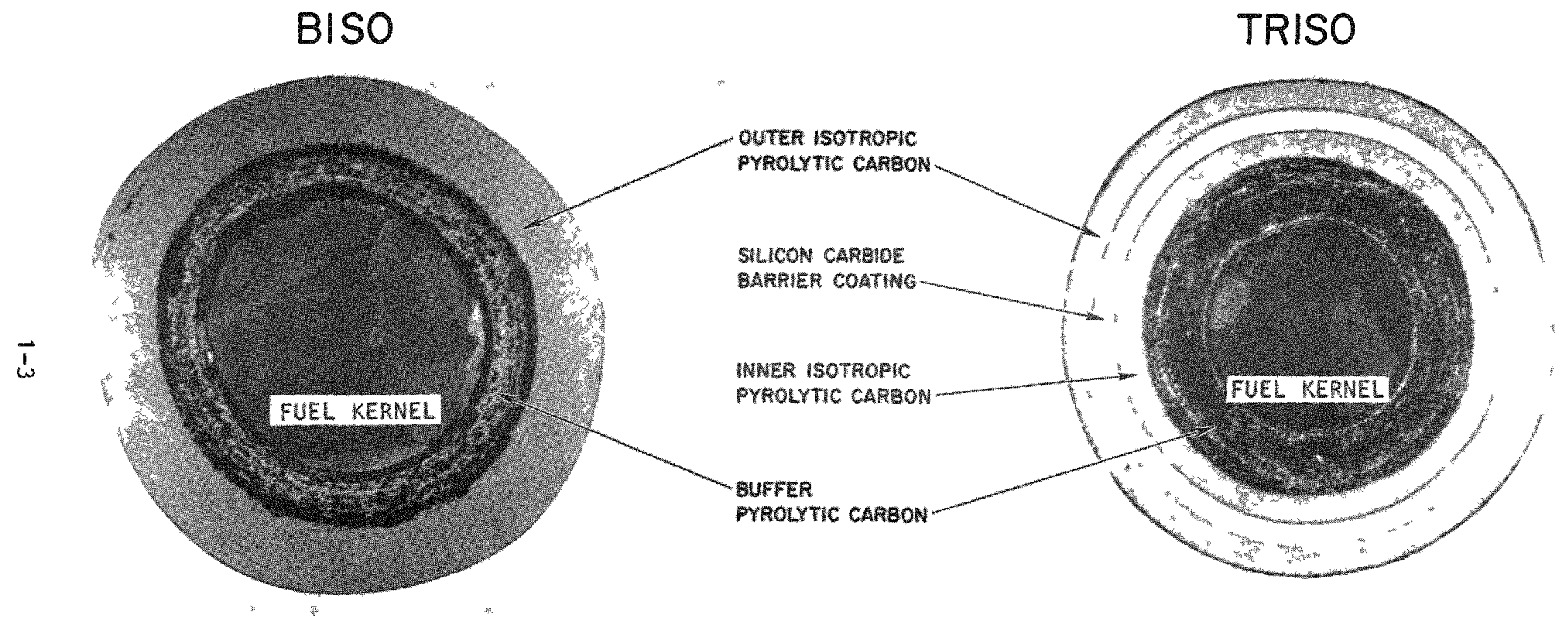

K72654

Fig. 1-2. HTGR coated fuel particles 


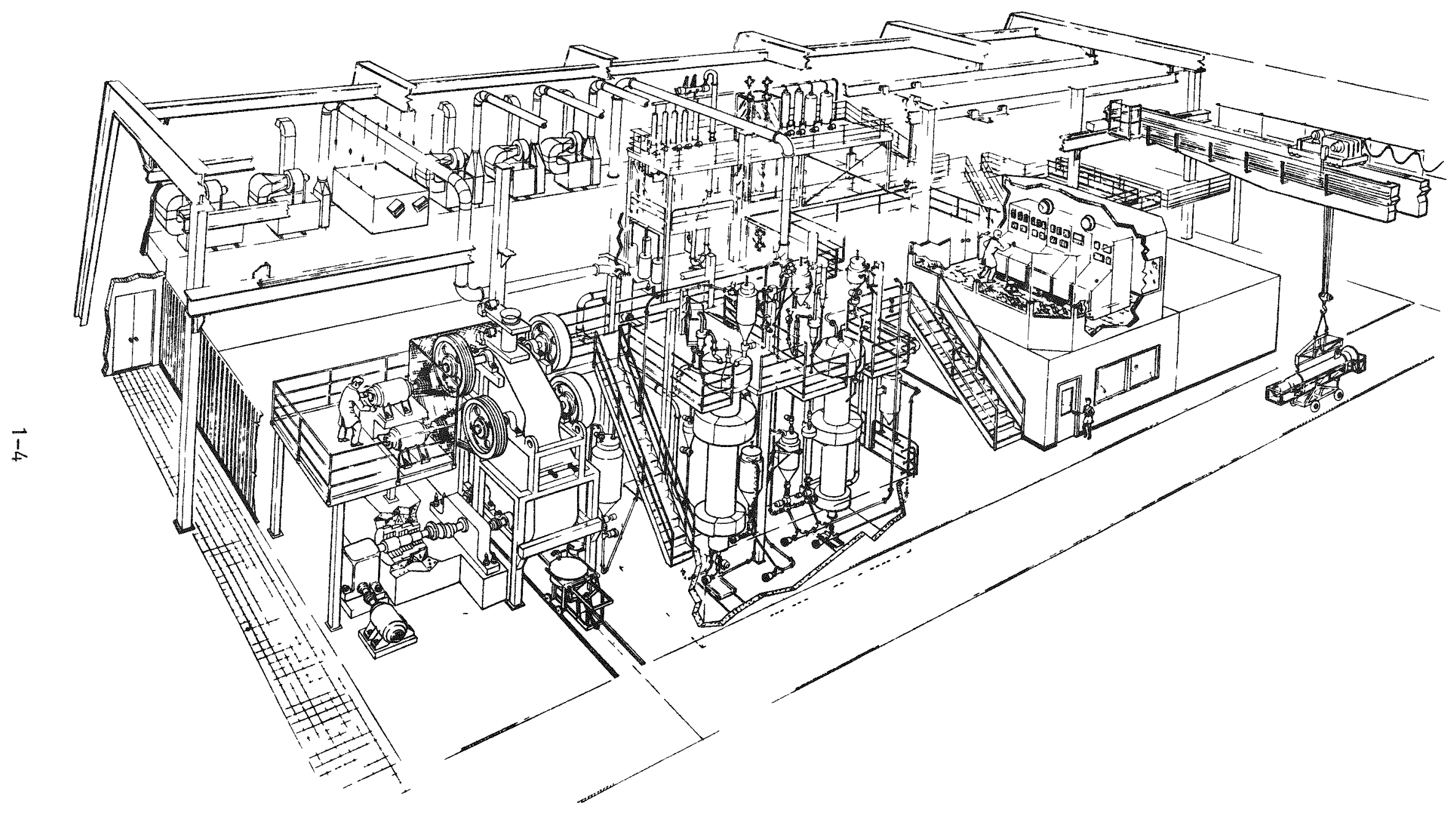

Fig. 1-3. HTGR reprocessing cold pilot plant arrangement 
This report describes the engineering-scale equipment in the pilot plant and summarizes the design features derived from the development work performed in the last few years. The background experimental information is available in Refs. 1-1 through 1-17. Appendix A contains the process flow diagrams and piping and instrumentation drawings, and Appendix $B$ contains the major assembly drawings.

\section{REFERENCES}

1-1. Yip, H. H., et a1., "Dissolution in HTGR Fuel Reprocessing, Interim Development Report," DOE Report GA-A15092, General Atomic Company, August 1978.

1-2. "Thorium Utilization Program Quarterly Progress Report for the Period Ending November 30, 1974," USAEC Report GA-A13255, General Atomic Company, February 15, 1975.

1-3. "Thorium Utilization Program Quarterly Progress Report for the Period Ending February 28, 1975," ERDA Report GA-A13366, General Atomic Company, May 30, 1975.

1-4. "Thorium Utilization Program Quarterly Progress Report for the Period Ending May 31, 1975," ERDA Report GA-A13510, General Atomic Company, August 15, 1975.

1-5. "Thorium Utilization Program Quarterly Progress Report for the Period Ending August 31, 1975," ERDA Report GA-A13593, General Atomic Conpany, September 30, 1975.

1-6. "Thorium Ut:1ization Program Quarterly Progress Report for the Period Ending November 30, 1975," ERDA Report GA-A13746, General Atomic Company, December 31, 1975.

1-7. "Thorium Utilization Program Quarterly Progress Report for the Period Ending February 29, 1976," ERDA Report GA-A13833, Genera1 Atomic Company, March 31, 1976.

1-8. "Thorium Utilization Program Quarterly Progress Report for the Period Ending May 31, 1976," ERDA Report GA-A13949, General Atomic Company, June 30, 1976.

1-9. "Thorium Utilization Program Quarterly Progress Report for the Period Ending August 31, 1976," ERDA Report GA-A14085, General Atomic Company, September 30, 1976. 
1-10. "Thorium Utilization Program Quarterly Progress Report for the Period Ending November 30, 1976," ERDA Report GA-A14214, Genera1 Atomic Company, December 1976.

1-11. "Thorium Utilization Program Quarterly Progress Report for the Period Ending February 28, 1977," ERDA Report GA-A14304, Genera1 Atomic Company, March 1977.

1-12. "Thorium Utilization Program Quarterly Progress Report for the Period Ending May 31, 1977," ERDA Report GA-A14441, General Atomic Company, June 1977.

1-13. "HTGR Fuel Recycle Program Quarterly Progress Report for the Period Ending August 31, 1977," ERDA Report GA-A14583, General Atomic Company, September 1977.

1-14. "HTGR Fuel Recycle Program Quarterly Progress Report for the Period Ending November 30, 1977," DOE Report GA-A14738, General Atomic Company, December 1977.

1-15. "HTGR Fuel Recycle Program Quarterly Progress Report for the Period Ending February 28, 1978," DOE Report GA-A14878, General Atomic Company, March 1978.

1-16. "HTGR Fuel Recycle Program Quarterly Progress Report for the Period Ending May 31, 1978," DOE Report GA-A15105, General Atomic Company, September 1978.

1-17. Hutton, Adrian E., "Dissolution of HTGR Fuel," ERDA Report GA-A13278, General Atomic Company, September 30, 1975. 


\section{HEAD-END REPROCESSING FLOW SHEET}

The purpose of the head end of the reprocessing flow sheet is to prepare fuel for solvent extraction. It comprises fuel element size reduction, crushed fuel element burning, particle classification, particle crushing, crushed particle burning, dissolution, and solidsliquid separation. Unit operations are connected by the solids handling system (Fig. 2-1).

Fuel elements are reduced to $-4760 \mu \mathrm{m}$ in a series of crushers (two overhead eccentric jaw crushers and one double-roll crusher) which are mounted in one frame; this system is referred to as the Uniframe. After screening, the crushed material is pneumatically conveyed to a product bunker and then to the feed bunker of the fluidized-bed crushed fuel element burner, which is referred to as the primary burner. The primary burner fluidizes crushed fuel elements with carbon dioxide and heats the initial charge with an induction heater. Oxygen is introduced to begin combustion, and cooling gas removes the heat of combustion transferred through the burner wall. The fluidized-bed temperature is maintained at around $900^{\circ} \mathrm{C}$. Fine particles are entrained by the fluidized gas and recycled to the bed after separation from the gas; fresh feed is continuously added to the burner. The graphite and outer carbon coatings are burned off, and the product is conveyed to the primary burner product bunker. The burner operates on a semicontinuous basis, i.e., only a part of the bed is dumped at any one time, until the end of an operating campaign. If the product is within specification, it is transferred to the pneumatic clsssifier feed bunker; if it contains excess carbon or graphite, it can be recycled to the primary burner feed bunker. The burned-back fuel particles are fed into a moving air stream within a zigzag classification column. 
FUEL ELEMENT SIZE REDUCTION SYSTEM
PRIMARY BURNER $\frac{\text { PNEUMATIC }}{\text { CLASSIFICATION }}$

SECONDARY BURNER $\frac{\text { PARTICLE }}{\text { CRUSHER }}$

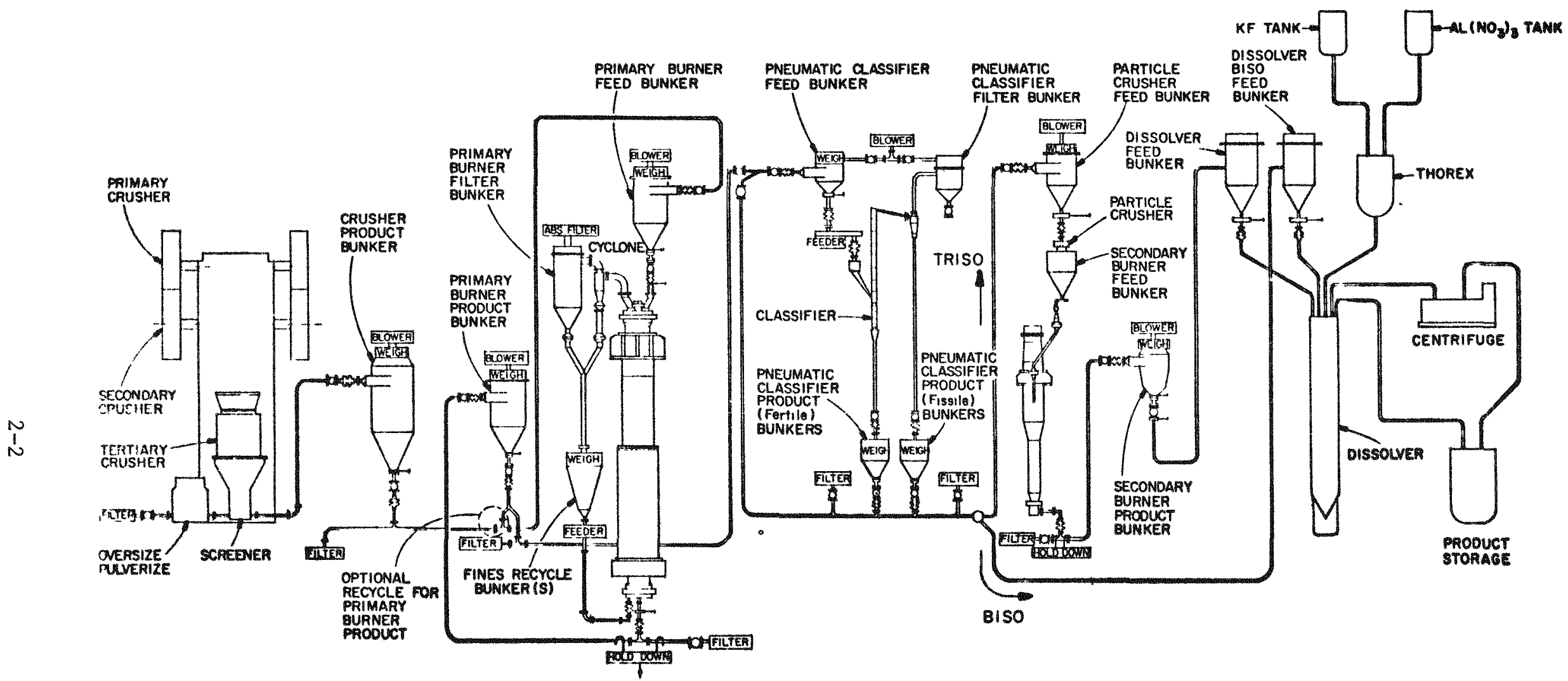

Fig. 2-1. Cold head-end 1ayout 
The light TRISO fissile particles are carried out of the top of the classifier, and the BISO particles, which are dense $\mathrm{ThO}_{2}$, fall out of the bottom, ready for dissolution and solvent extraction. In the event of unsatisfactory separation, particles from either or both classifier product bunkers can be recycled for reclassification.

The burned-back TRISO particles still contain inner carbon coatings which must be burned. They are conveyed to a particle crusher (where they are crushed), and the crushed particles are fed to the fluidized-bed crushed particle burner (or secondary burner), which combusts carbon and converts heavy metal carbides to oxides. The batch of feed is fluidized with carbon dioxide and induction heated prior to the introduction of oxygen. Product from the secondary burner is pneumatically transported to the secondary burner product bunker.

The fuel particles are then ready for dissolution. The fertile Tho 2 kernels from the classifier underflow product bunker and the secondary burner product are pneumatically conveyed to the dissolver-surge bunkers for material accountability prior to dissolution. For fertile kernel dissolution, Thorex acid solution [13 $\left.\mathrm{HNO}_{3} / 0.05 \mathrm{M} \mathrm{KF} / 0.1 \mathrm{M} \mathrm{Al}\left(\mathrm{NO}_{3}\right)_{3}\right]$ is used. The resultant $\underline{1}$ thorium-containing product solution is processed through the feed adjustment equipment prior to entering the solvent extraction process. However, for the reference fissile fuel ash, $2 \mathrm{M} \mathrm{HNO}_{3}$ is required to dissolve the heavy metal oxides. The resultant slurry, consisting of the insolubles and dissolved heavy metals, must be further clarified through a centrifuge, which separates the solids from the liquid. The mother liquor is then directly transferred to the solvent extraction system. 


\section{DISSOLVER-CENTRIFUGE SYSTEM}

The $0.5-\mathrm{m}$ dissolver-centrifuge system is an engineering-scale system comprised of a number of subsystems:

1. Dissolver.

2. Condenser.

3. Solids feed bunkers.

4. Centrifuge.

5. Repulp tank.

6. Chemicals makeup and product storage tanks.

Figures 3-1 through 3-3 show the system arrangement in the pilot plant. Stainless steel drip pans are provided to catch any spill of acid or solvent. A 1.016-tonne (1-ton) crane above the system is used for maintenance of the centrifuge, the repulp tank, and the dissolver. The dissolver-centrifuge subsystems are described below.

3.1. DISSOLVER

3.1.1. Dissolver Vessel

The dissolver is a $304 \mathrm{~L}$ stainless steel vessel $(0.5 \mathrm{~m}$ in diameter and $3 \mathrm{~m}$ in length) with a jacketed conical bottom and a jacketed cylindrical section. A flanged dissolver top is included in the design to allow for any addition of internals to the dissolver, if needed. Figure 3-4 shows a cross-sectional view of the dissolver. Steam is supplied to the bottom jacket to heat the contents of the vessel and to assist in agitation of the solution. The cylindrical side jacket provides steam heating or water cooling to maintain the desired solution temperature in the dissolver. The 90-degree conical bottom reduces material holdup in the dissolver and enhances steam jet transfer of slurries. As observed in steam jet 


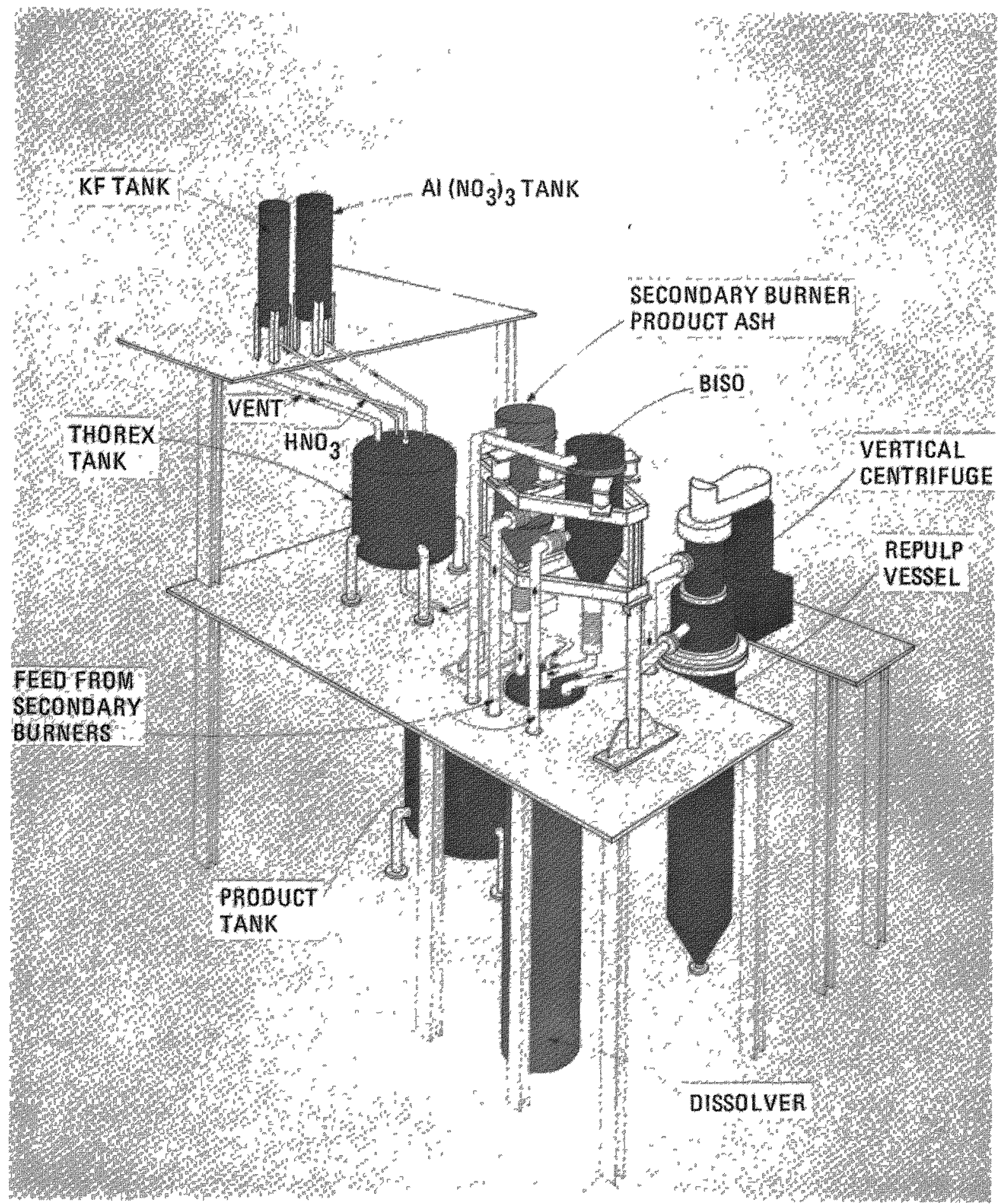

Fig. 3-1. 0.5-m dissolver-centrifuge system arrangement 


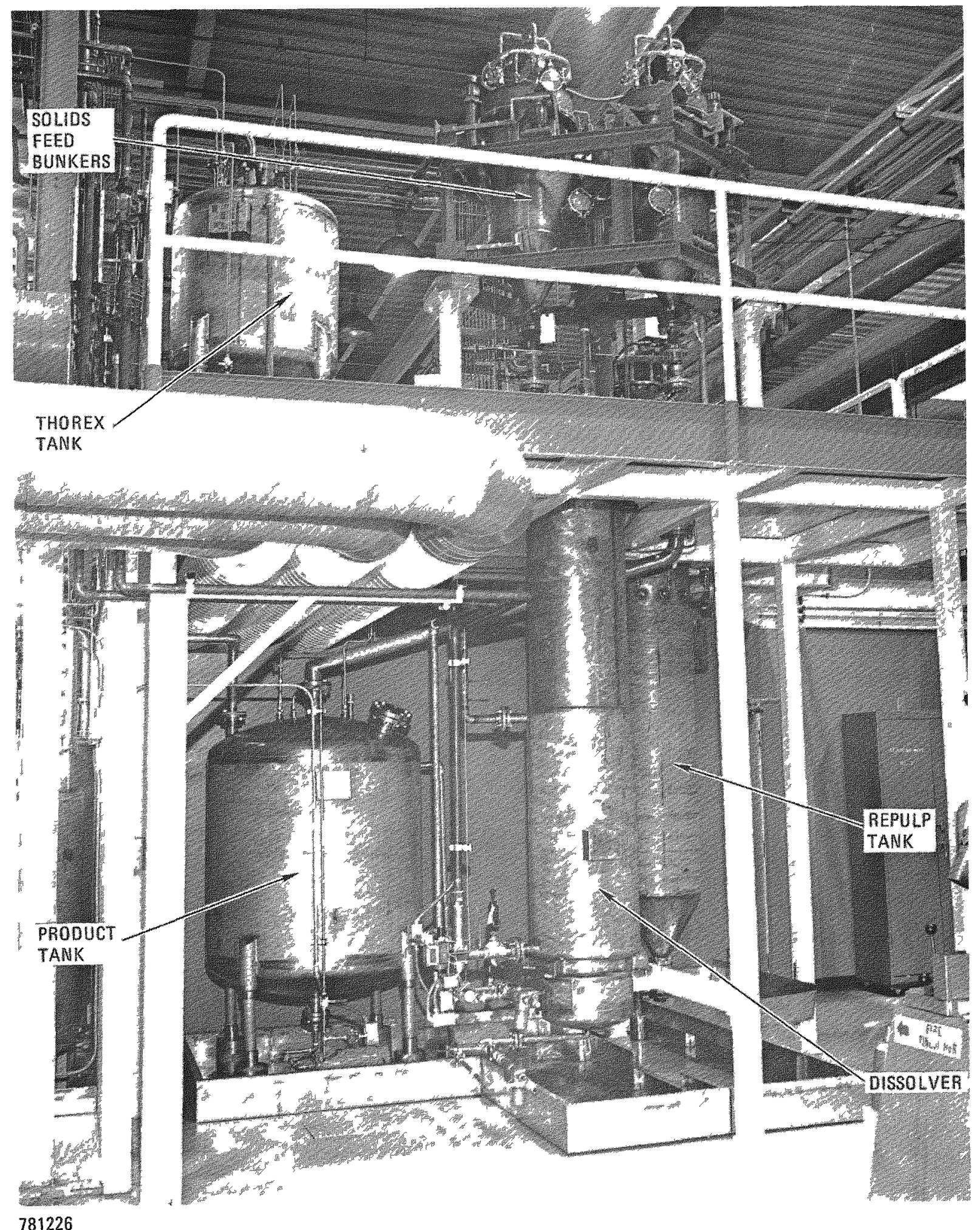

Fig. 3-2. Dissolver-centrifuge system (1ooking south) showing dissolver without insulation. The piping connecting to the dissolver supplies steam and cooling water to the bottom and side jackets. 


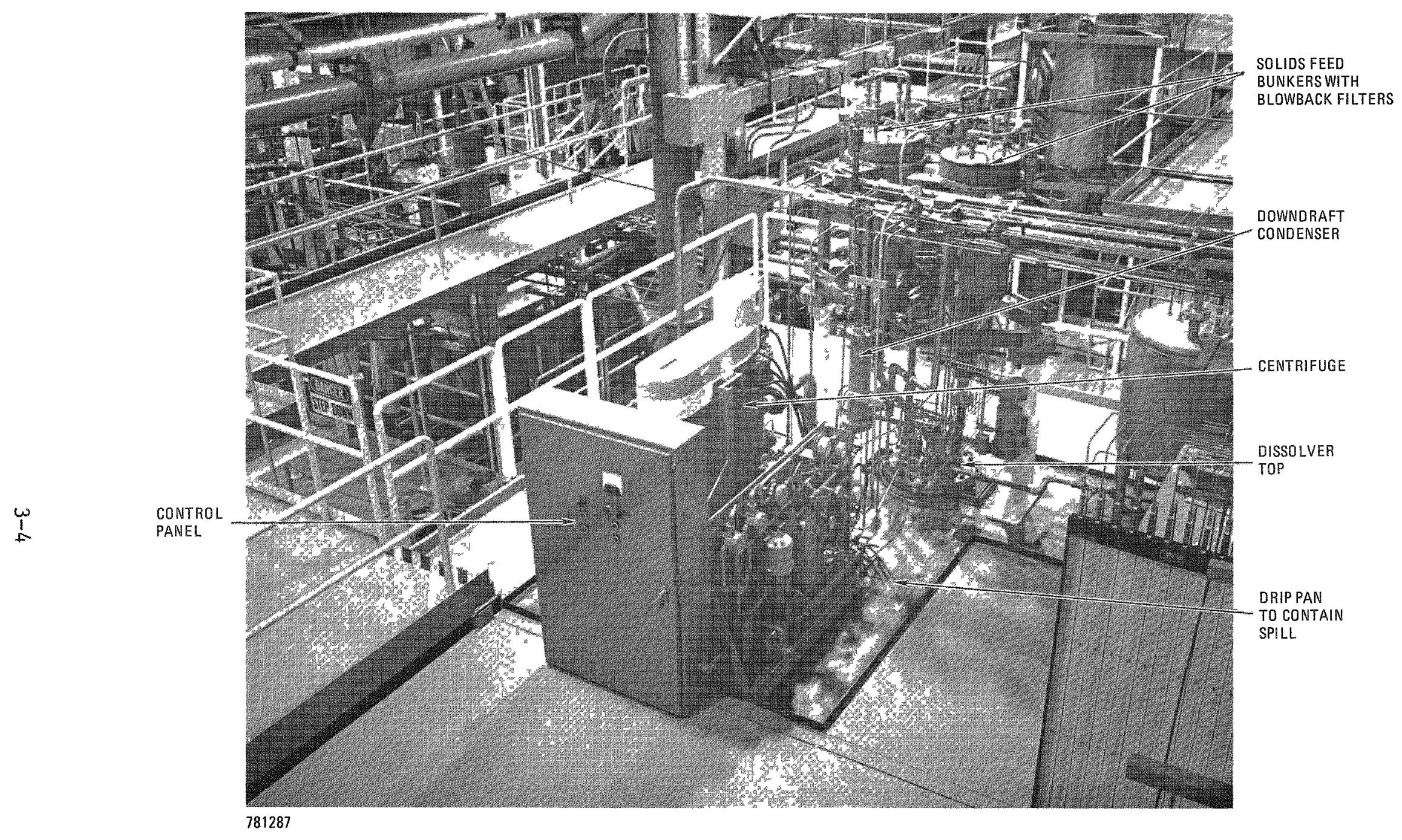

Fig. 3-3. Dissolver-centrifuge system viewed from upper deck 


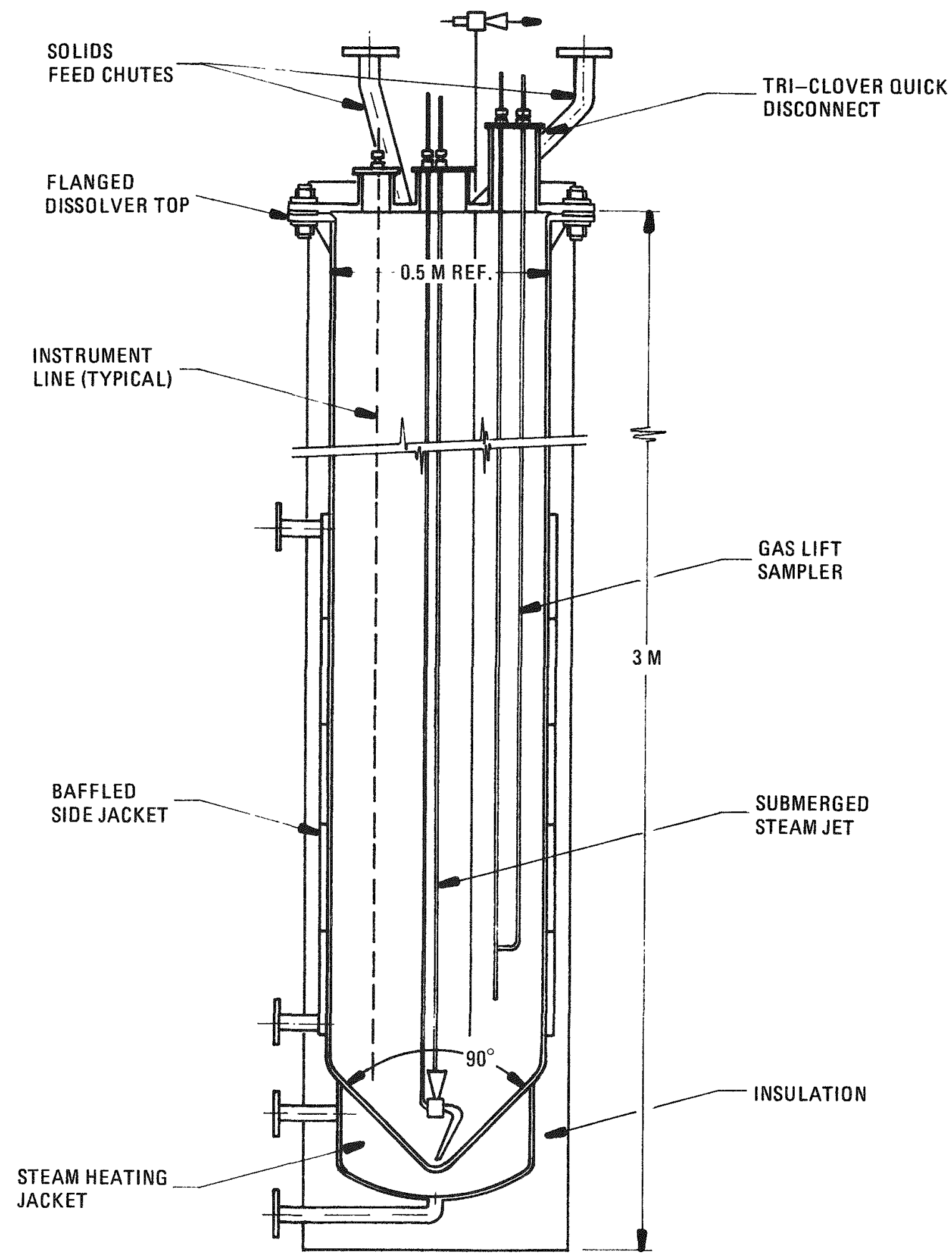

Fig. 3-4. Dissolver cross section 
transfer tests, it is necessary to cool the dissolver solution to less than $60^{\circ} \mathrm{C}$ before transfer to ensure efficient slurry transport.

\subsubsection{Product Remova1}

Product solution and the undissolved residues are removed from the dissolver by a submerged steam jet equipped with a short pickup tube, as shown in Fig. 3-5. The jet body consists of three threaded parts and can be disassembled for inspection of jet erosion, plugging, or corrosion. The short pickup tube together with the bottom conical geometry allows almost complete removal of the slurry from the dissolver. A decanting jet is available for use if it is desired only to remove dissolver solution from the dissolver. When the steam jet is not in use, a low purge gas flow is maintained to keep the opening from plugging.

\subsubsection{Dissolver Solids Feed}

Solids fuels are penumatically conveyed from the secondary burner product bunker and the classifier product bunker to the two surge bunkers on top of the dissolver. The solids fuel is gravity fed to the dissolver in a batch. A rotary feeder also allows metering of the solids into the dissolver, if necessary, to permit reaction rate control. A clamp heater and a nitrogen purge are maintained in the feed chute to prevent bridging of solids caused by vapor condensation in the chute during the dissolution cycle.

\subsubsection{Instrumentation}

A11 process and instrument lines penetrate through the top of the dissolver. Samples may be withdrawn from the dissolver with a gas lift sampler. Instrument dip legs, thermocouples, a sampling gas 1ift, sparge lines, and submerged steam jets, which are susceptible to plugging or corrosion, can be removed from the dissolver through Tri-Clover quick disconnects (see Fig. 3-6). 


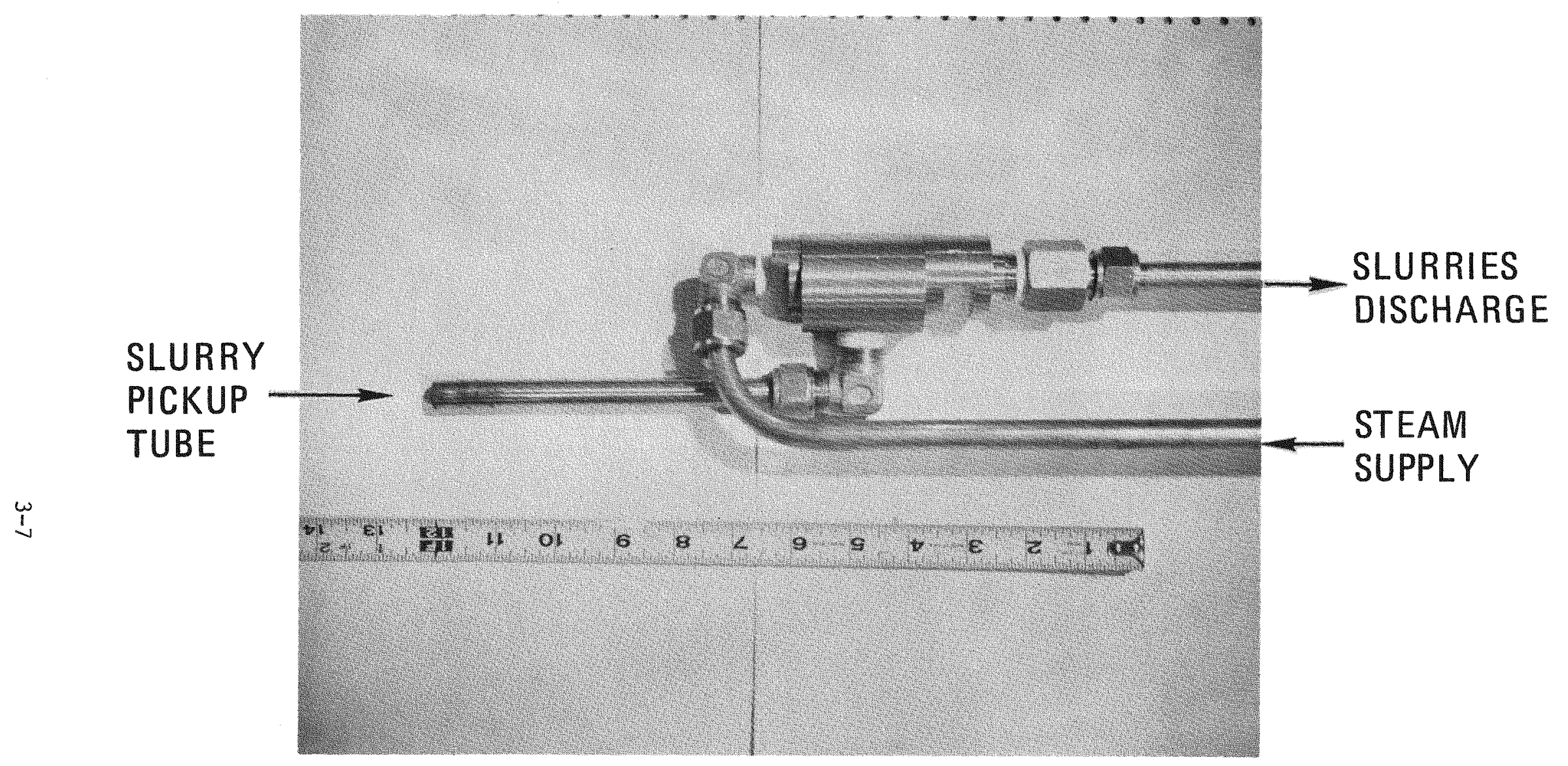

Fig. 3-5. Submerged steam jet for slurry transfer from dissolver to centrifuge 


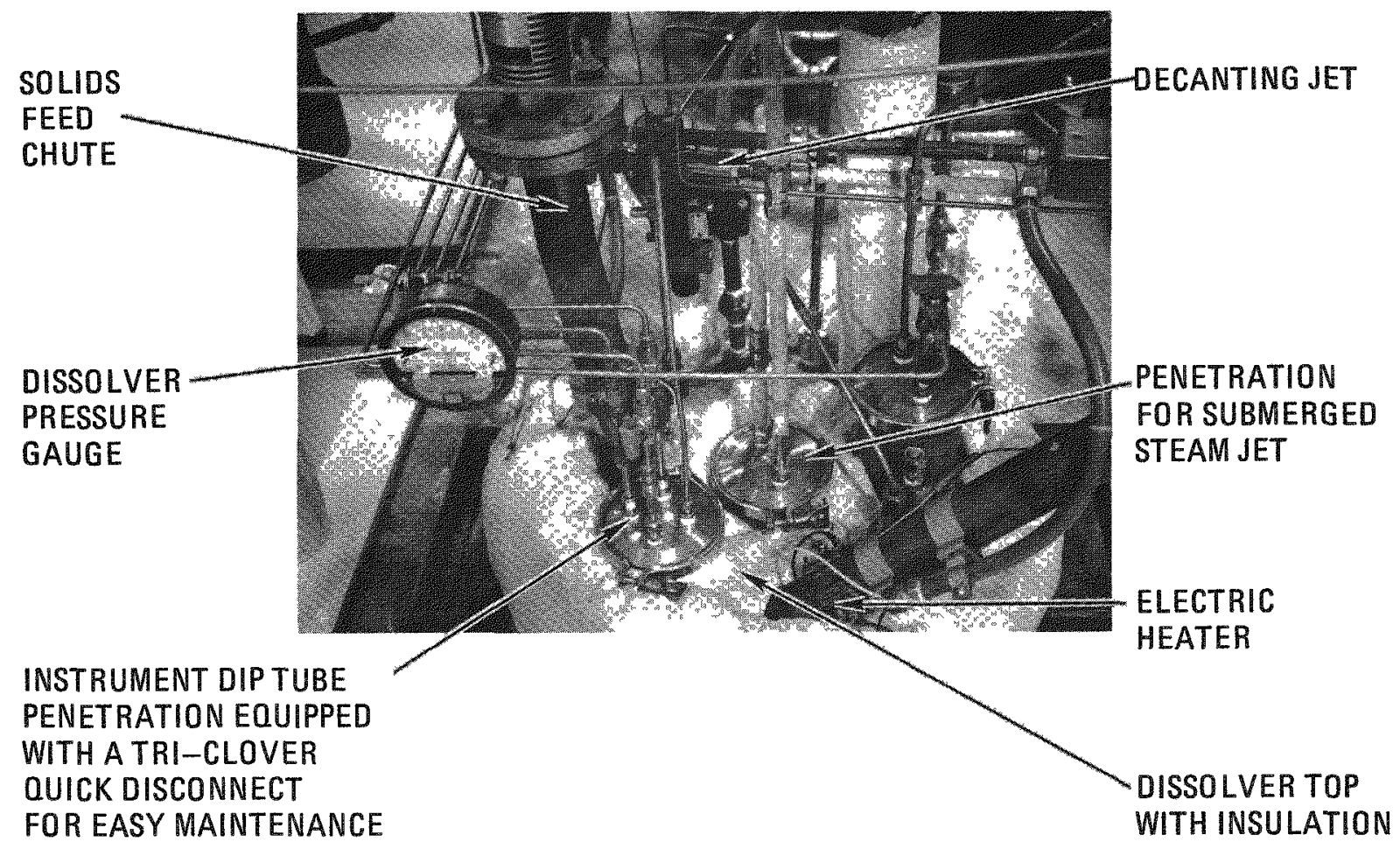

Fig. 3-6. Dissolver top penetrations 
In a reprocessing plant, a soluble neutron poison will be added for criticality control in the dissolver.

\subsubsection{Operating Cycle}

3.1.5.1. BISO Fuel Dissolution. Once separated from the TRISO fissile particles in the classifier, the BISO fertile stream is ready for dissolution. To reduce the dissolution time, excess BISO particles are added and the dissolution is stopped before the kernels have completely dissolved. This is called heel operation.

Two-hundred liters of Thorex solution $\left[13 \mathrm{M} \mathrm{HNO}_{3} / 0.05 \mathrm{M} \mathrm{KF} / 0.1 \mathrm{M} \mathrm{Al}\left(\mathrm{NO}_{3}\right)_{3}\right]$ is prepared in the Thorex tank and is transferred by gravity to the dissolver. Then a total of $88 \mathrm{~kg}$ BISO kernels are added to the solution through a heated feed chute. The solution is brought to boiling at about $120^{\circ} \mathrm{C}$ by supplying steam to the dissolver cone. A sparge gas is maintained to promote agitation before the onset of boiling and to help volatilize iodine from the dissolver solution. When $60 \%$ of the feed (53 $\mathrm{kg}$ ) has dissolved to yield a $1 \underline{M}$ thorium concentration, the solution is cooled with the cooling jacket.

With the sparge off, the mother liquor is decanted from the remaining solids and is transferred by steam jet to the product tank. Fresh Thorex is added to the dissolver containing the undissolved kernels. An amount of kernels equal to $60 \%$ of the first charge is added, and the slurry is brought to a boil. When $40 \%$ of the solids remain, the slurry is again cooled.

The mother liquor is decanted again, and more Thorex and feed are added. This cycle is repeated a number of times until the end of an accountability lot is reached or the insoluble content (cross-mixed fissile particles, SiC hulls, carbon, etc.) reaches a predetermined level. 
At this point the mother liquor is decanted and sufficient Thorex is added to dissolve the remaining BISO kernel heel. On the complete dissolution, the entire contents are transferred by steam jet to the centrifuge for further product clarification.

\subsubsection{WAR Fissile Fuel Dissolution. During secondary burner} operations, the uranium oxycarbide core material of weak acid resin (WAR) fissile particles is converted to finely divided $\mathrm{U}_{3} \mathrm{O}_{8}$. The principal reaction in the dissolution is

$$
\mathrm{U}_{3} \mathrm{O}_{8}+8 \mathrm{HNO}_{3} \rightarrow 3 \mathrm{UO}_{2}^{++}+6 \mathrm{NO}_{3}^{-}+4 \mathrm{H}_{2} \mathrm{O}^{+}+2 \mathrm{NO}_{2}^{\uparrow} .
$$

The evolution of nitrogen dioxide in dissolver operations is potentially troublesome because foaming may occur, with resultant handling problems. However, no vigorous reaction or foaming was observed when $2 \mathrm{M}$ nitric acid was added to the secondary burner ash charged to the bench-scale dissolver or during subsequent heating to the boiling point $\left(104^{\circ} \mathrm{C}\right)$. Figure $3-7$ shows a sample of WAR fissile ash before and after dissolution in the $0.13-\mathrm{m}$ dissolver.

Based on the pilot plant study for WAR fissile ash, a batch fissile dissolver operating cycle has been developed. Solids feed to the dissolver is by batch ( $40 \mathrm{~kg}$ ), and owing to the low bulk density $\left(1.3 \mathrm{~g} / \mathrm{cm}^{3}\right)$ of the solids, they are added before the introduction of dilute nitric acid at $\sim 25^{\circ} \mathrm{C}$ to avoid poor mixing. Continuous metering of feed could be utilized, but this has the potential disadvantage of the feed bridging at the feed chute, especially if the fissile ash is wetted by condensation from boiling nitric acid.

Since peak $\mathrm{NO}_{\mathrm{X}}$ concentration in the off-gas treatment system ${ }^{\mathrm{NO}} \mathrm{X}$ converter must be limited to less than $10,000 \mathrm{ppm}$, the process will be controlled at a lower temperature (i.e., below boiling), at least in the first few hours of the cycle, to control the reaction rate. After the 


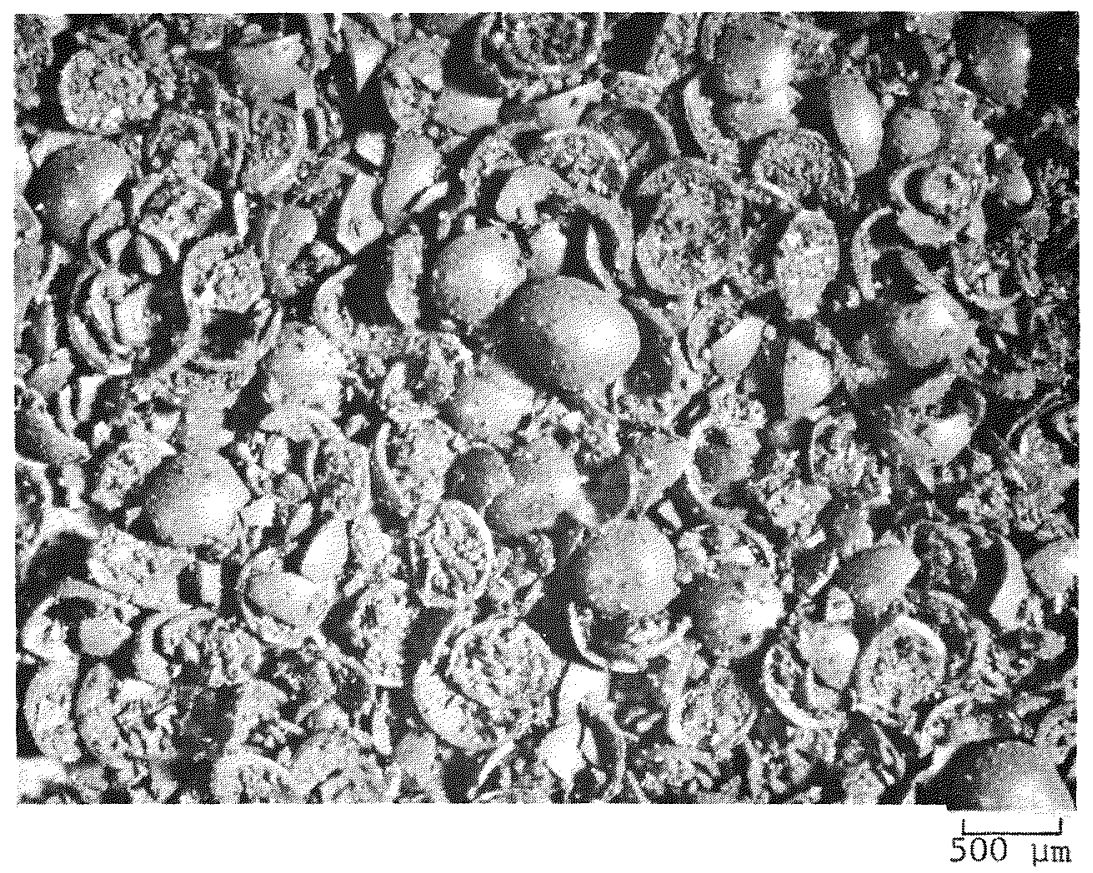

(a) WAR fissile secondary burner ash before dissolution

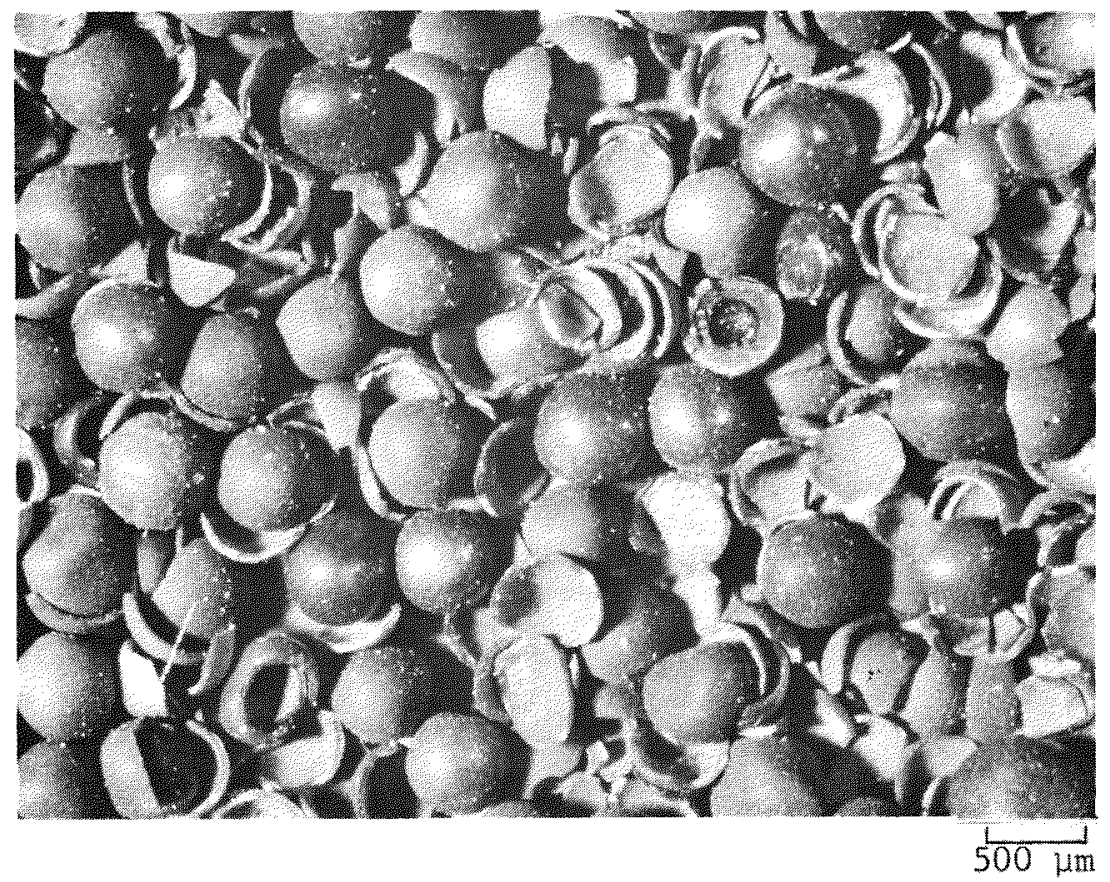

(b) WAR fissile dissolver residue after dissolution consisting of SiC hulls and unbroken particles

Fig. 3-7. WAR fissile dissolver feed and residue 
bulk of the uranium is dissolved, the solution temperature can be brought to the boiling point to dissolve as much residue as possible and to volatilize iodine. Since the dissolution curves at ambient and boiling temperature are widely separated, using temperature to control $\mathrm{NO}_{\mathrm{X}}$ evolution is relatively effective. Sparge gas is required to promote mixing, especially in the nonboiling portion of the cycle. At the same time, the sparge gas dilutes the $\mathrm{NO}_{\mathrm{X}}$ evolved in the reaction. In commercial operation, a soluble neutron poison would be included in the dissolver solution as a criticality precaution.

\subsection{CONDENSER}

The dissolver off-gas vents through a downdraft condenser, which condenses nitric acid vapor and cools the noncondensable to less than $60^{\circ} \mathrm{C}$. The condensate is returned to the dissolver through a loop seal. The cooled noncondensable will be sent to the dissolver off-gas treatment system for further processing. The cooling water to the condenser is instrumented for flow and temperature measurements required for a heat balance. The reflux liquid temperature can be measured and the liquid can be sampled.

\subsection{SOLIDS FEED BUNKERS}

Solids fuel is pneumatically transferred from storage hoppers to the dissolver surge bunkers. These surge bunkers contain enough feed to process one dissolver batch. Load cells on which the bunkers rest provide material accountability. To assist burner ash flow, an aeration pad is provided in the cone section of the secondary burner and hopper. Mott sintered-metal blowback filters are required to protect the conveying blower from particulate contamination.

\subsection{CENTRIFUGE}

To separate the undissolved solids from the dissolver solution, a Sharples continuous vertical centrifuge is employed. In order to obtain 
such a separation, it is necessary that the solid particles have a higher density than the liquid phase. The Sharples centrifuge (Model P-850 SUPER-D-CANTER) has a $0.1524-\mathrm{m}$ (6-in.) bow1, rotates up to $8000 \mathrm{rpm}$, and develops up to $5400 \mathrm{~g}$ in centrifugal force. As shown in Figs. 3-8 and 3-9, the vertical centrifuge is mounted on a structural frame and is belt-driven by a constant speed 10-hp motor. The wetted surfaces are made of Type 316 stainless steel.

The vertical centrifuge differs in design from the horizontal units in more aspects than orientation. In the vertical design the bowl is suspended from the top, where the only seal is located. This "plumb bob" suspension allows the bowl to absorb slight imbalances through shifting of the axis of rotation. A horizontal unit is supported at both ends and cannot absorb imbalances, but instead reacts to give increased vibration. The ability of the vertical centrifuge to absorb imbalances also relaxes the tolerance required for balancing the bowl.

For remote operation in a hot cell, several features unique to the vertical design give it an advantage over the horizontal unit:

1. It requires less floor space.

2. Removal and replacement of the internals are simplified with a vertical orientation, and the vertical centrifuge is similar in design to the batch centrifuges used in remotely maintained facilities and would be easier to adapt to this service using existing technology.

3. The seal is not in contact with the process fluids, and the unit self-drains if stopped.

Figure 3-10 illustrates the operating principle of the vertical centrifuge. The feed slurry to be separated is introduced into the conveyer feed zone through an axially mounted feed tube. It then discharges 


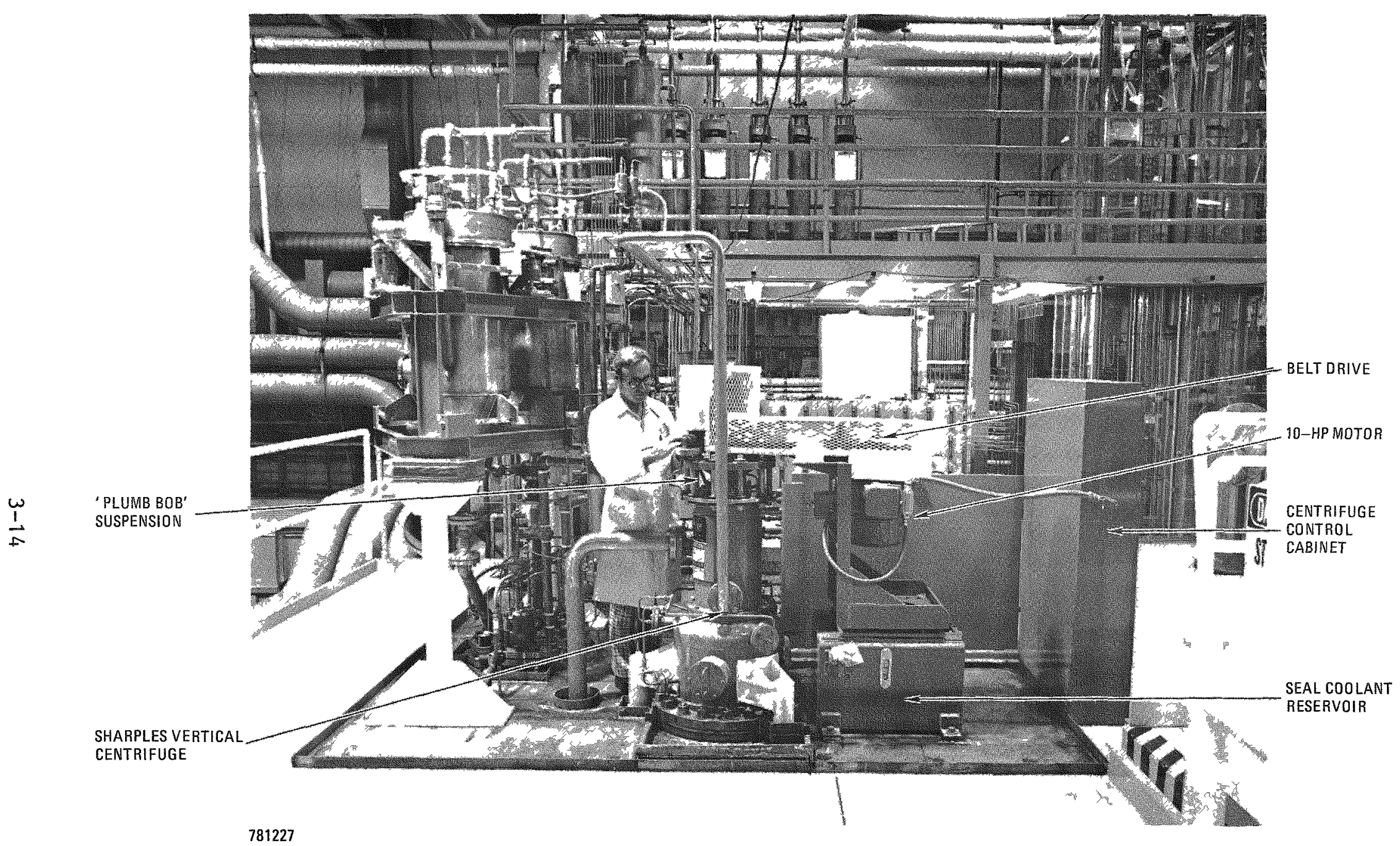

Fig. 3-8. Sharples Model P-850 vertical centrifuge as installed on upper deck 


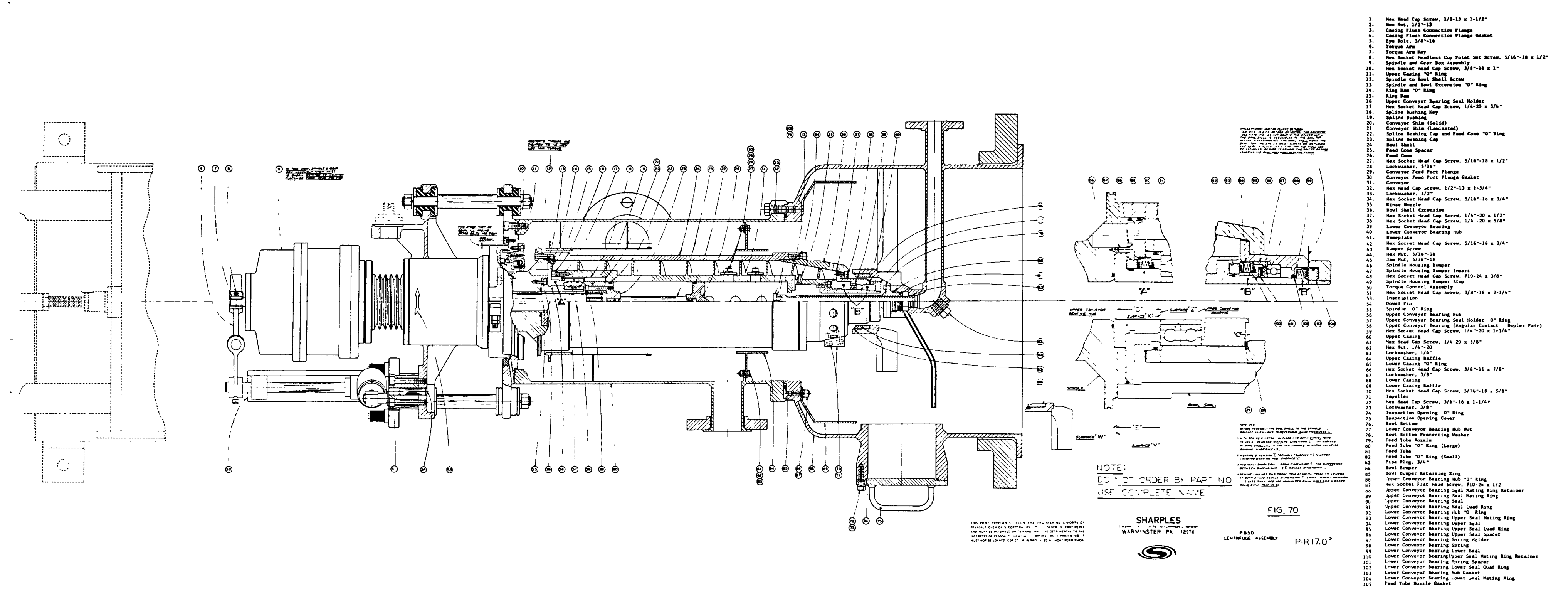

PERMISSION TO REPE DOUE GRANTED BY SHARPLES CORP

Fig. 3-9. Cross section of Sharples Mode1 $\mathrm{P}-850$ vertical centrifuge 


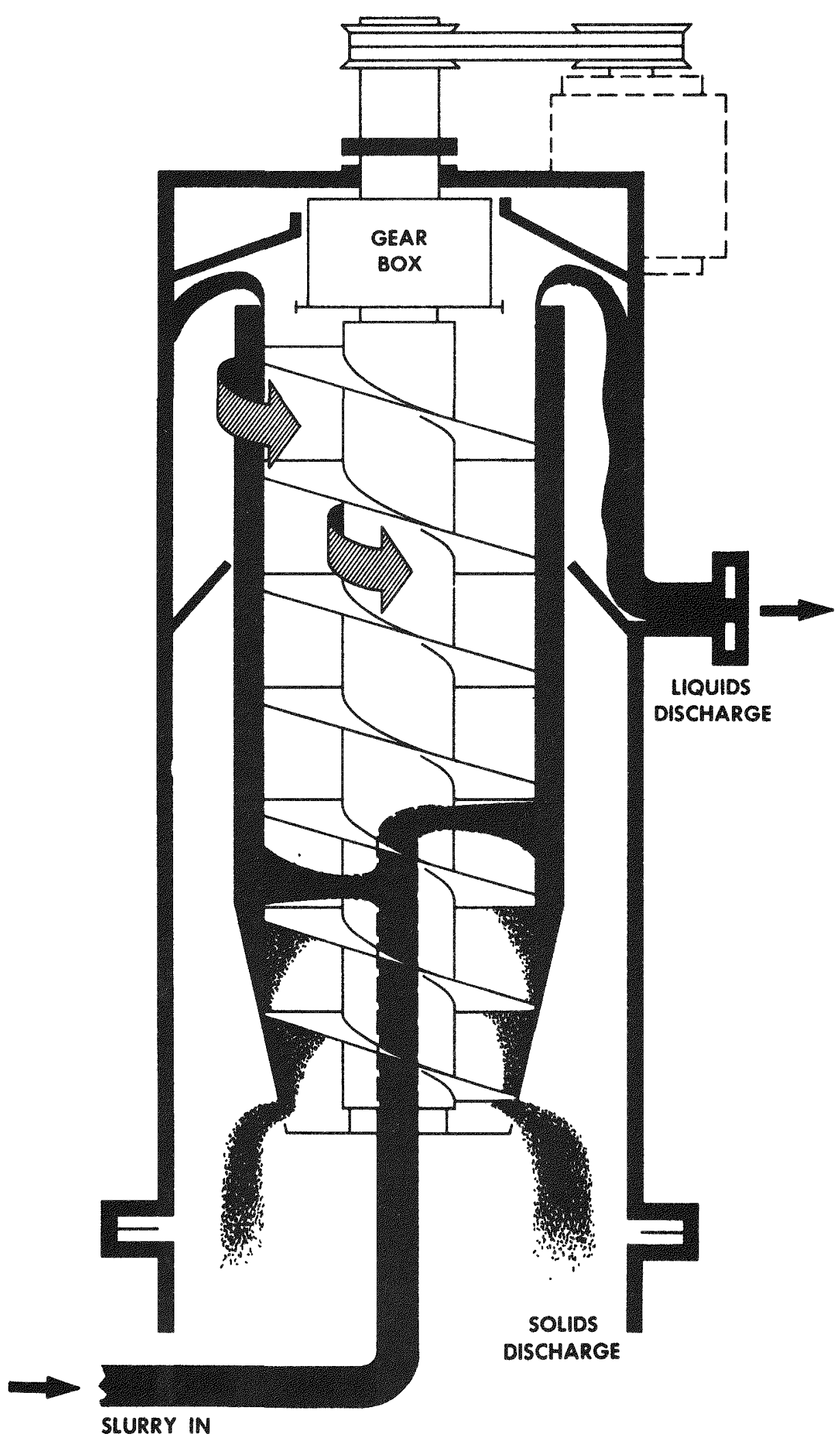

Fig. 3-10. Operation of a continuous vertical centrifuge 
from ports, located around the periphery of the feed zone, into the bowl. As solids separate out of the slurry, they are carried by centrifugal force to the wall of the bowl, where they are moved along the bowl wall by the conveyer over the inclined beach of the bowl extension and out the solids discharge ports located around the periphery of this extension. The solids then drop directly into a holding vessel which is directly coupled to the centrifuge casing. Any solids held up in the casing are flushed down with the casing-rinse spray nozzles as shown in Fig. 3-11.

A separate recirculating lubrication system supplies oil mist lubrication to the bearings and coolant to the main seals in the centrifuge. Although this lubrication system is placed next to the centrifuge in the pilot plant as shown in Fig. 3-12, it can be easily modified for installation outside a hot cell away from the centrifuge to avoid unnecessary degradation of the lubricant.

\subsection{REPULP TANK}

The repulp tank contains the solids discharged from the centrifuge and maximizes recovery of occluded heavy metals from the solids by rinsing with water or dilute acid. As shown in Fig. 3-13, the repulp tank is directly coupled to the bottom of the centrifuge. While the solids are in the tank, a gas sparge keeps them well mixed with the rinse solution. After a thorough rinse, the slurry is transported back to the dissolver either via a submerged jet or through the bottom drain valve.

\subsection{CHEMICALS MAKEUP AND PRODUCT STORAGE TANKS}

All chemical storage and product storage tanks are free-standing, made of Type 304L stainless steel, and bottom-drained. A gas sparge or a recirculating pump is used to mix the contents. All tanks are vented to the vessel off-gas system. 


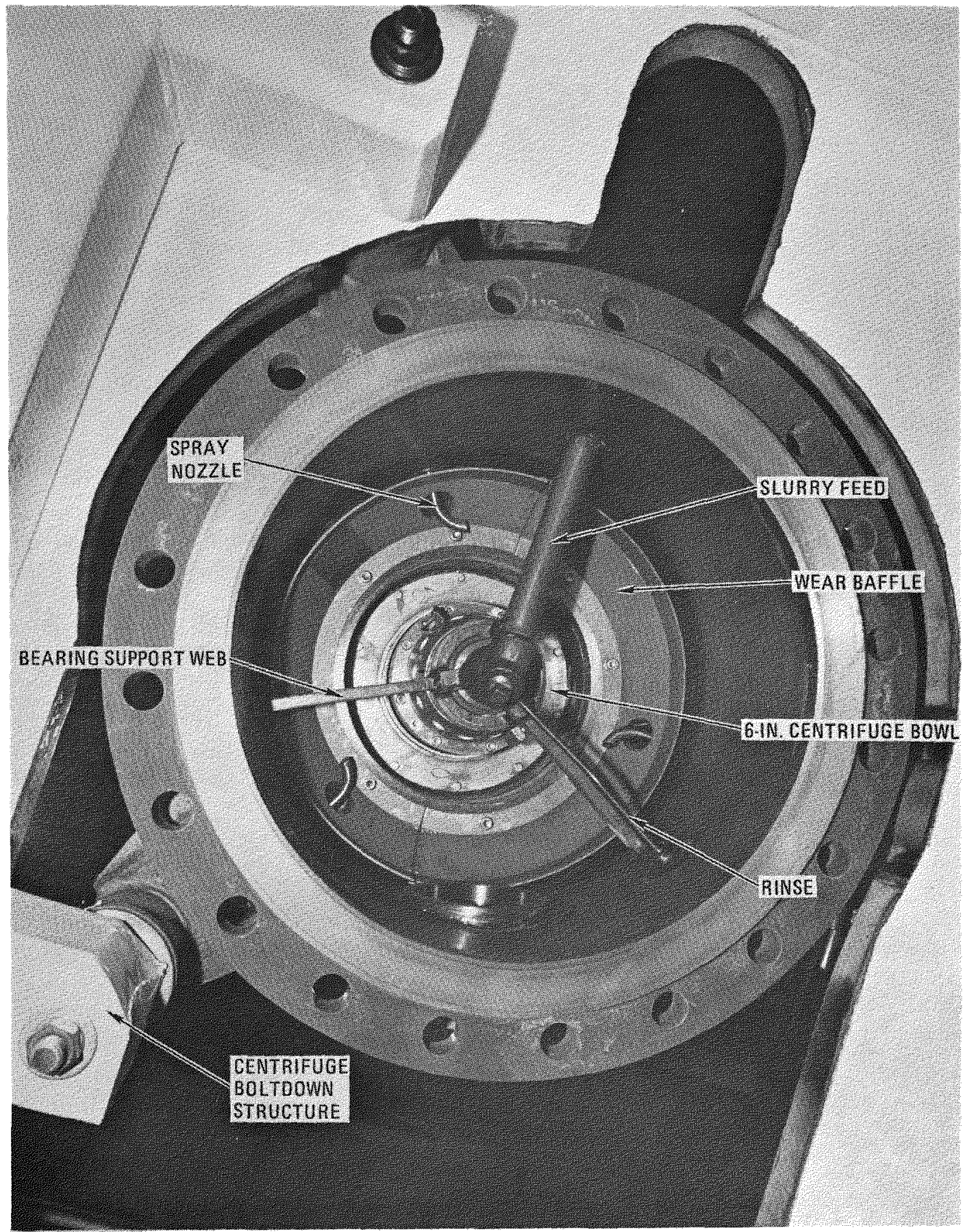

135-36-211-7

Fig. 3-11. Vertical continuous centrifuge solids discharge 


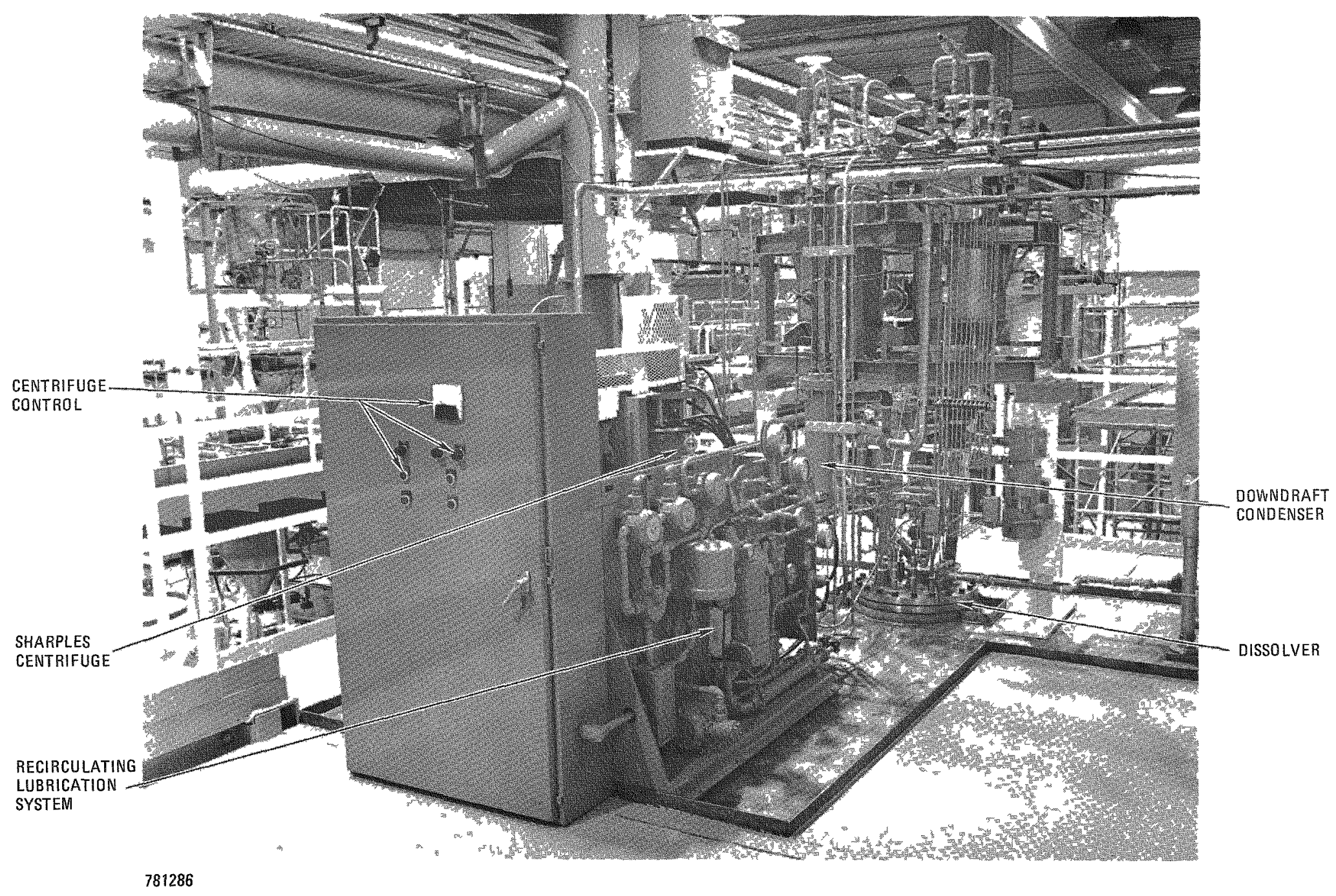

Fig. 3-12. Centrifuge lubrication system 


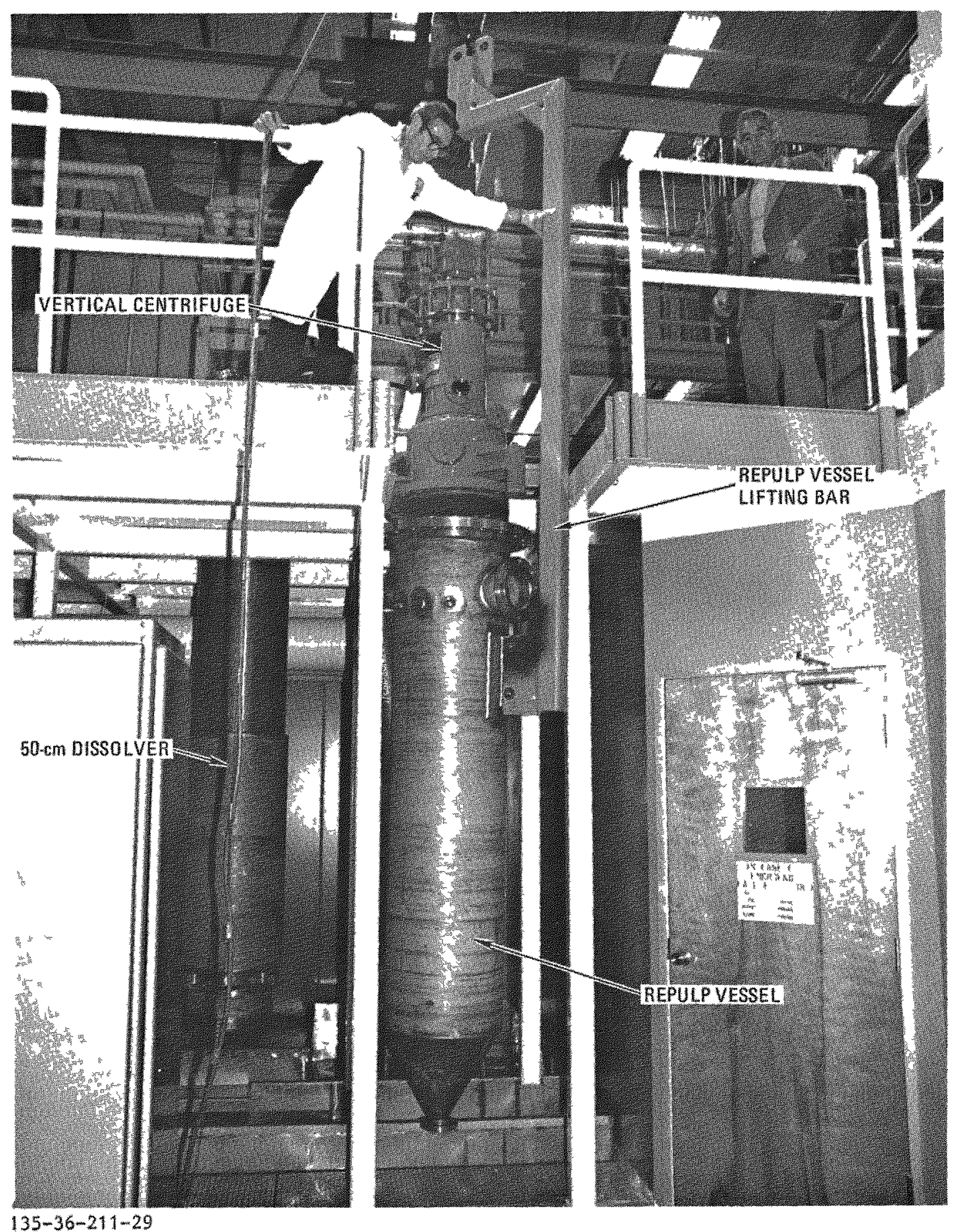

Fig. 3-13. Repulp vessel being lifted into position for coupling with centrifuge 


\subsection{PROCESS INSTRUMENTATION AND CONTROL}

The dissolver-centrifuge system can be operated manually from the control panel next to the centrifuge shown in Fig. 3-14. The panel houses the centrifuge and dissolver controls, relays, and power supply. For liquid level and specific gravity monitoring, manometers and differential pressure transducers are used.

Alternatively, the dissolver-centrifuge system can be operated entirely inside the central control room from two control cabinets, where data logging and push-button control can be carried out without leaving the room. Alarms and automatic protection are also provided. Figures 3-15 and 3-16 show the features on the control cabinets. 


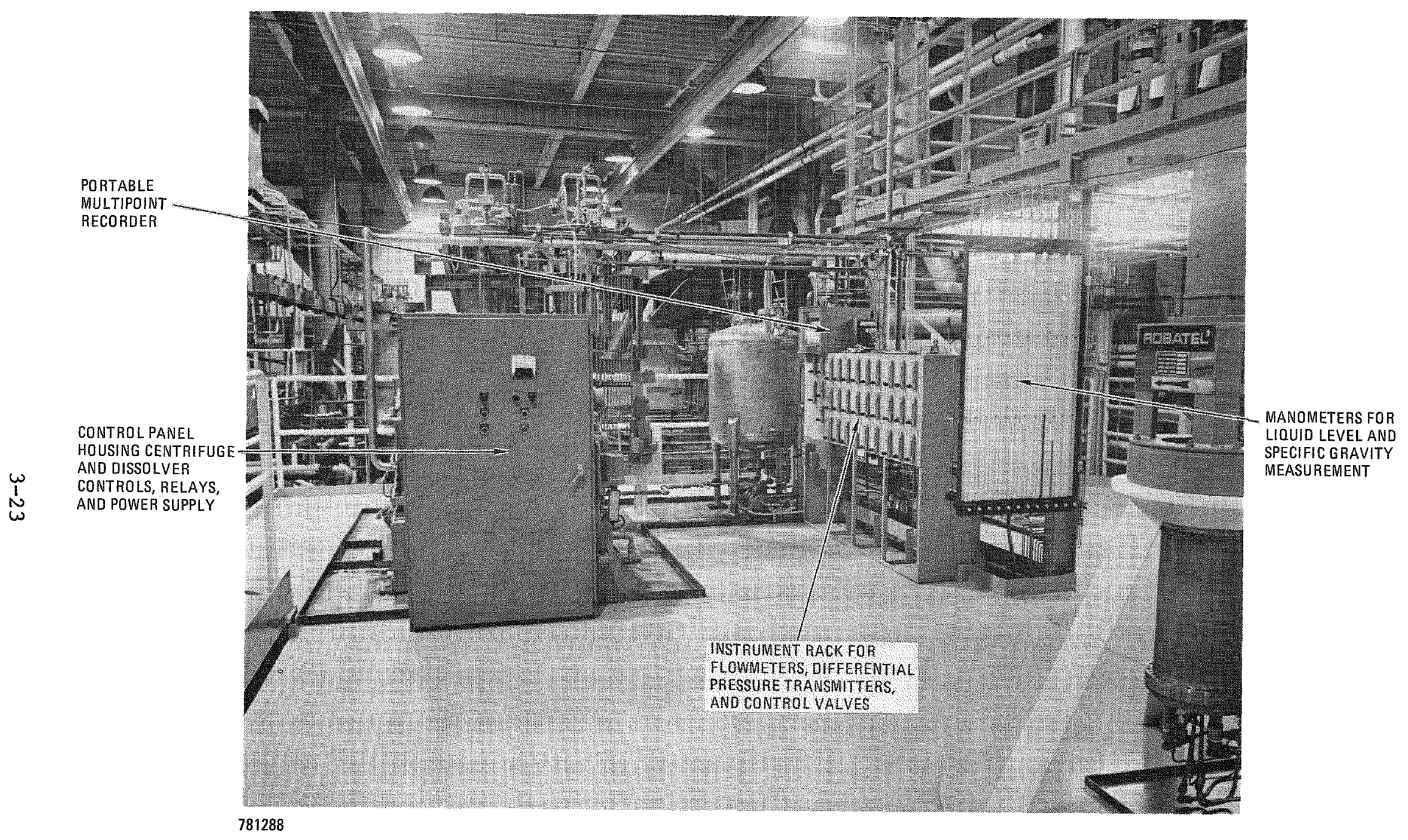

Fig. 3-14. Instrumentation and control panels for dissolver-centrifuge system 


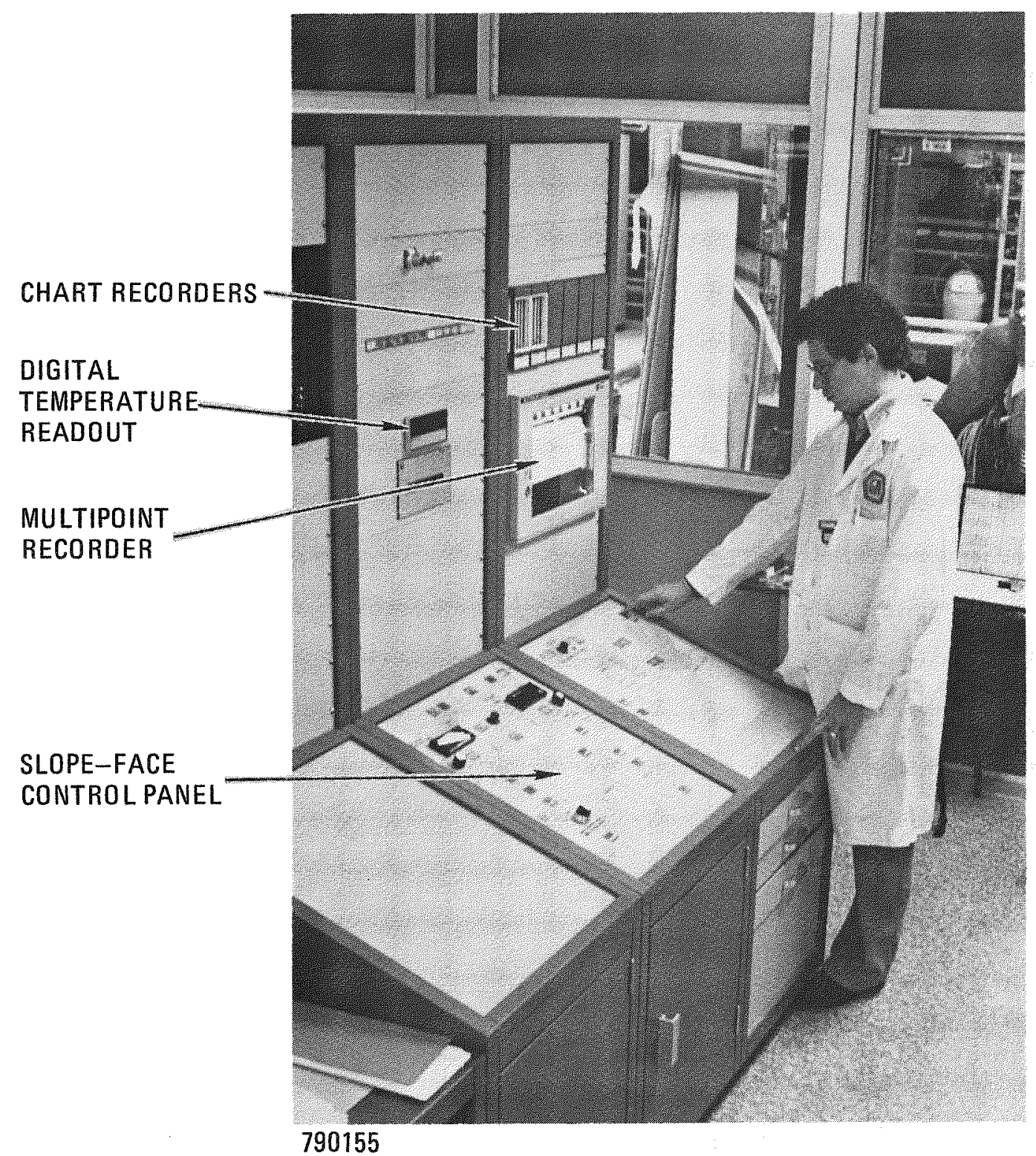

Fig. 3-15. Control cabinets inside central control room 


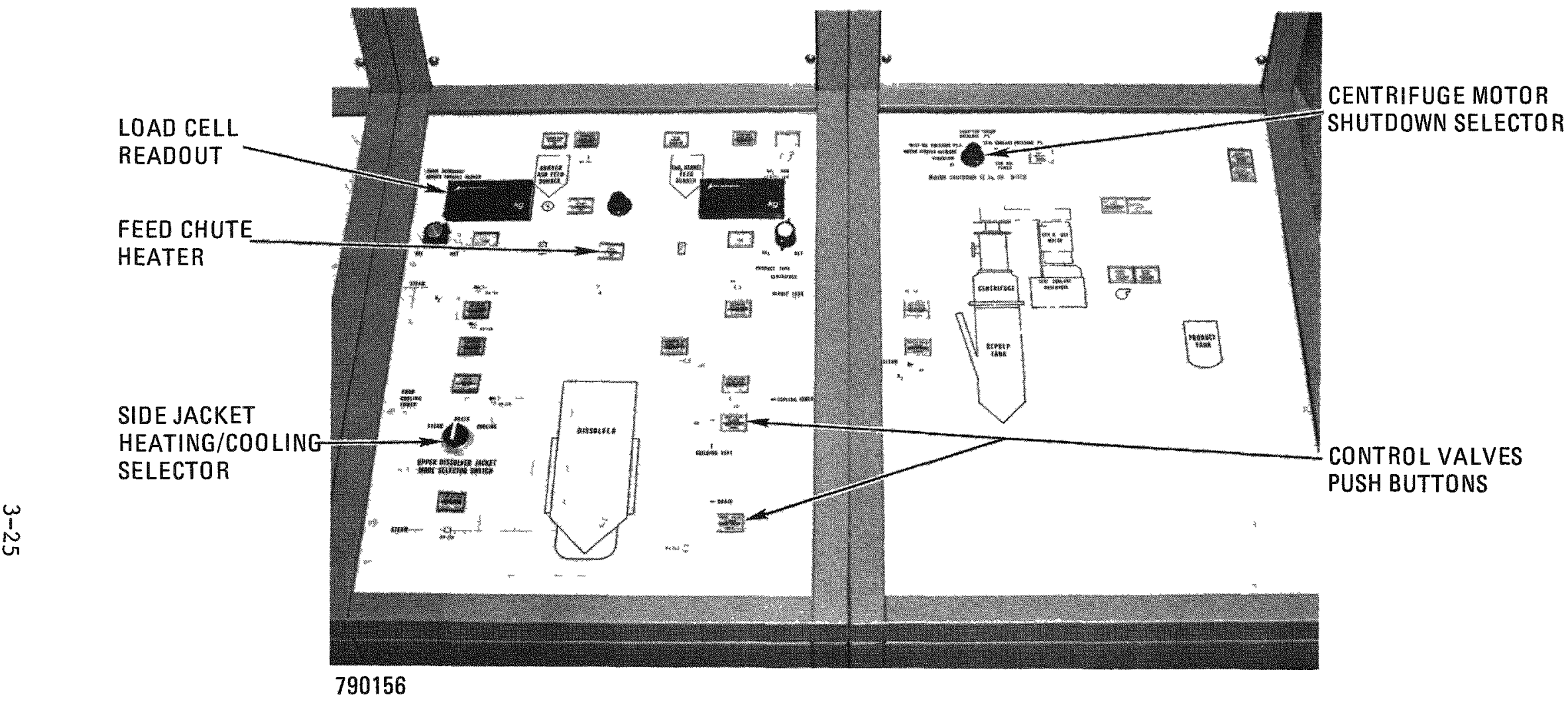

Fig. 3-16. Control cabinet slope-face control layout 
APPENDIX A

PROCESS FLOW DIAGRAMS

AND

PIPING AND INSTRUMENTATION DRAWINGS 
-

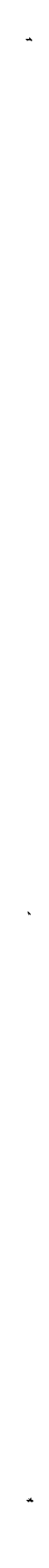

- 


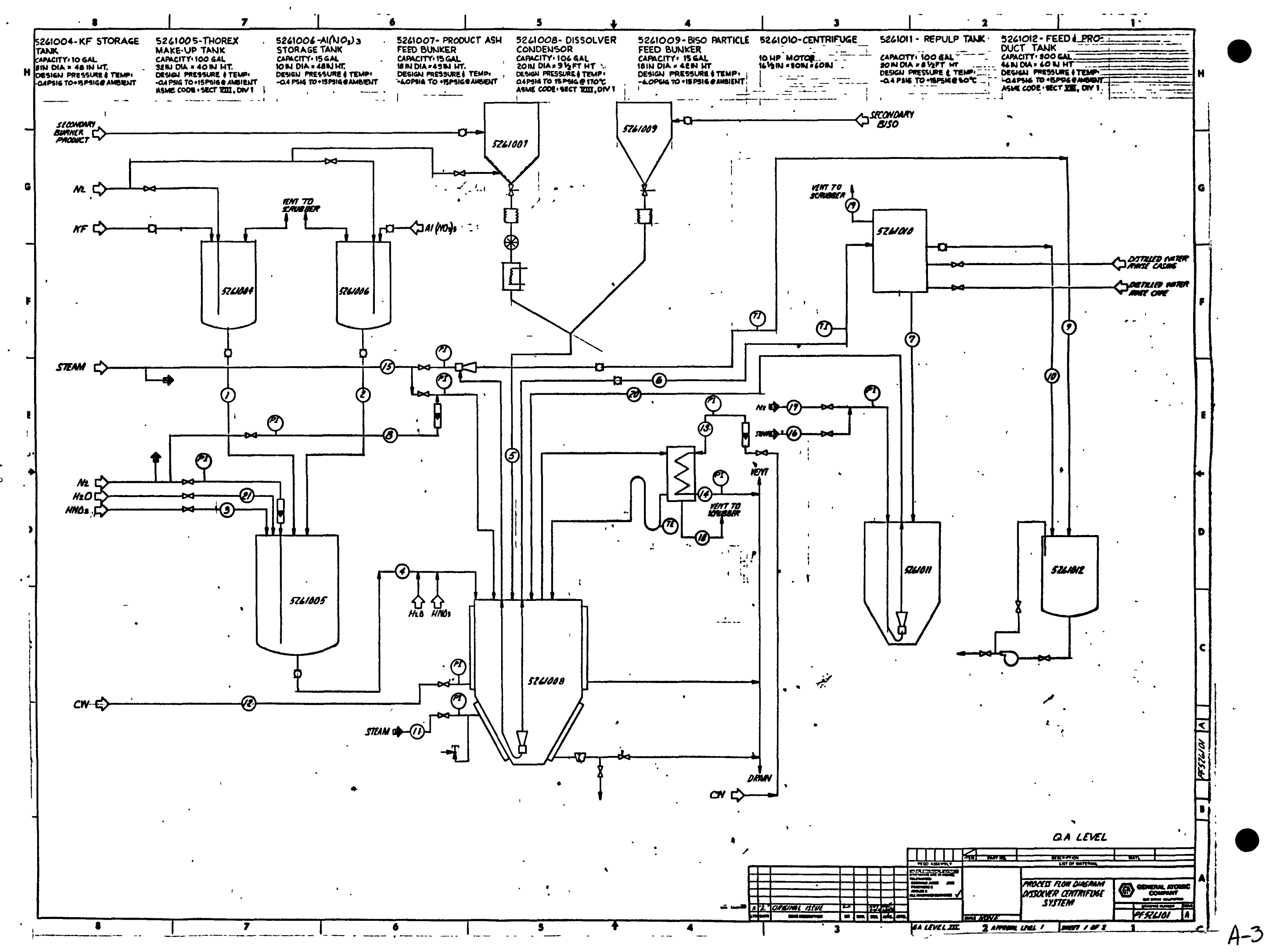


FERTLE BISO CAMPAGN

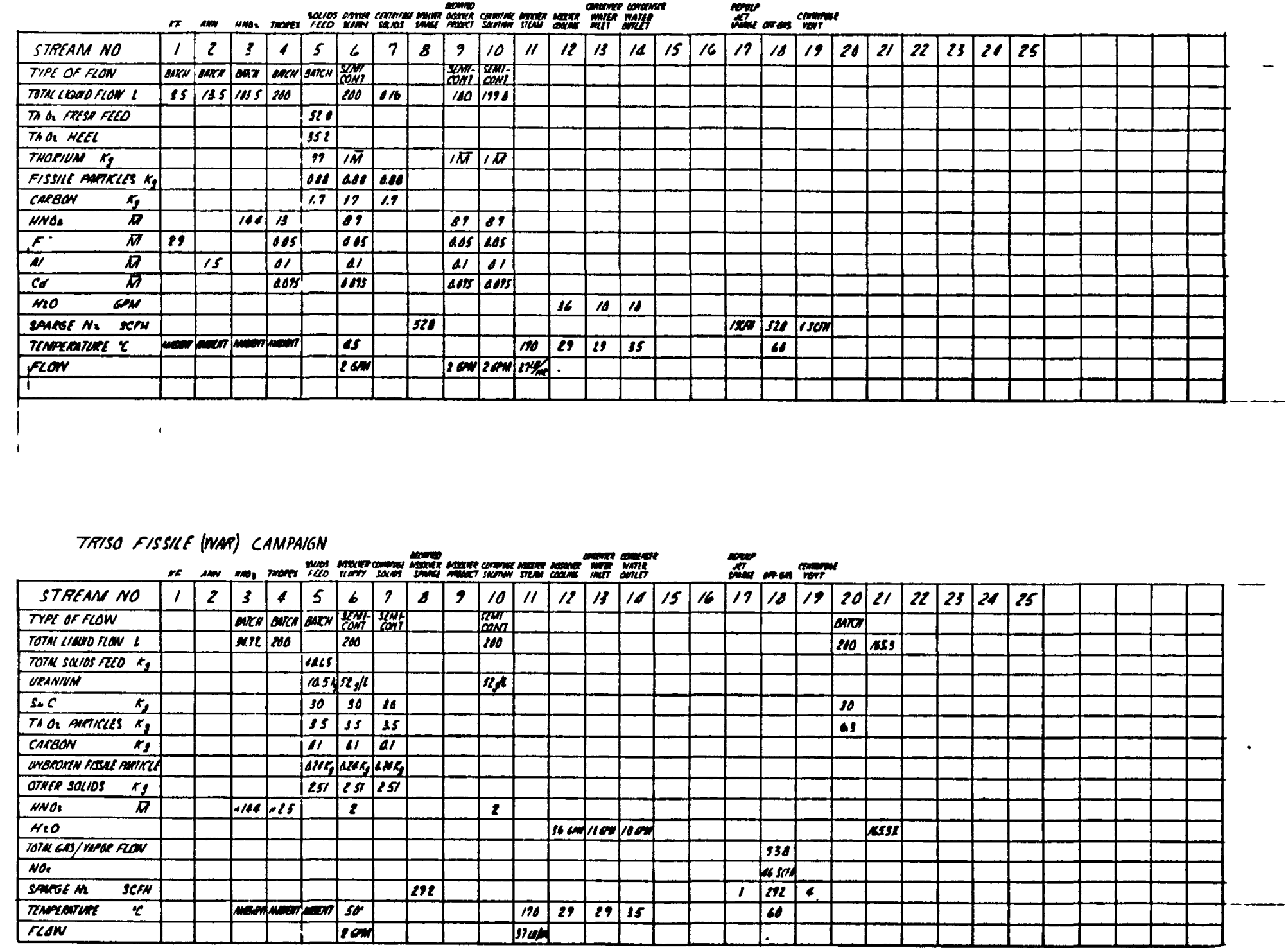

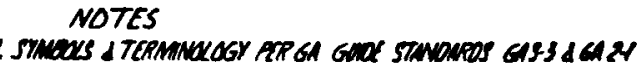




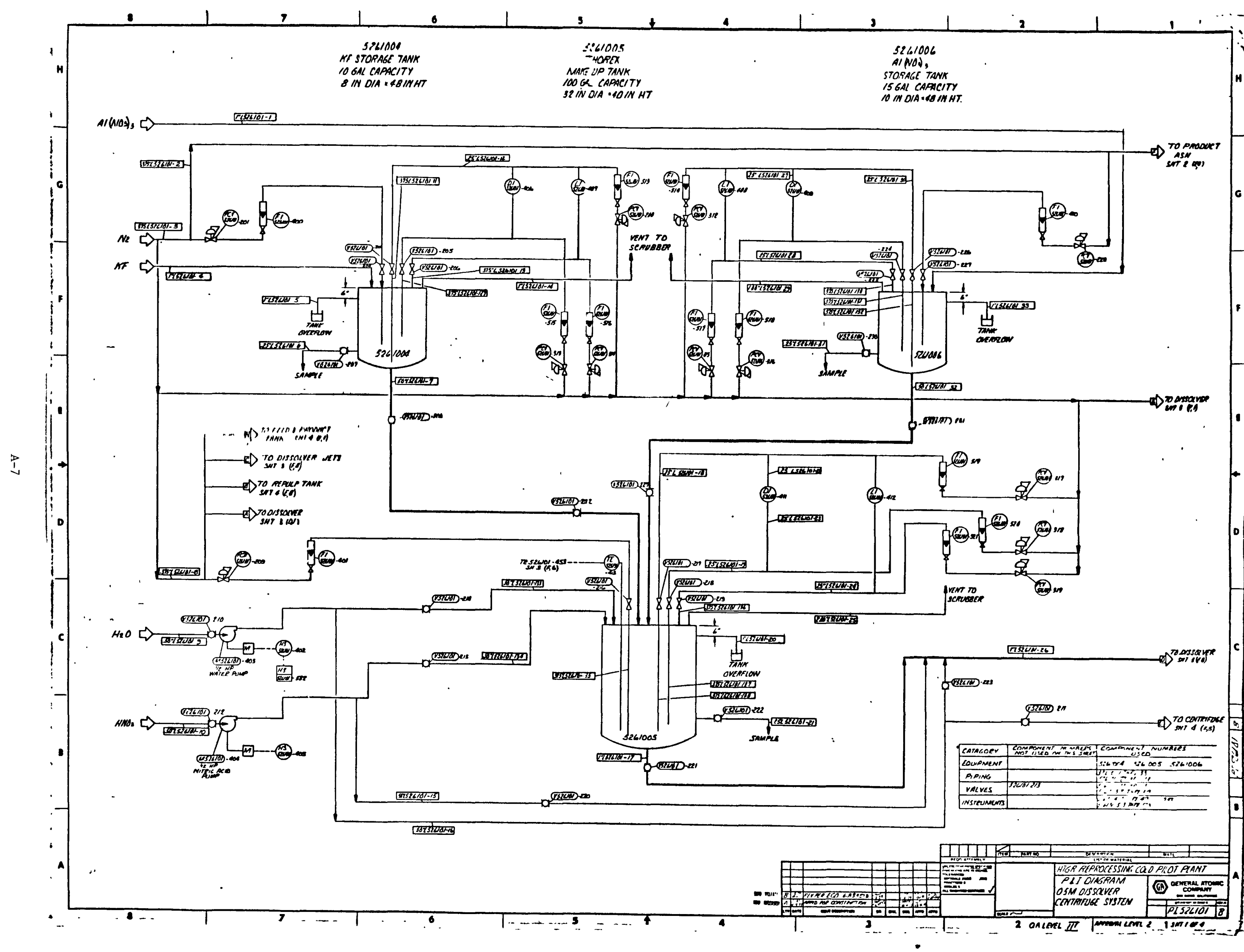




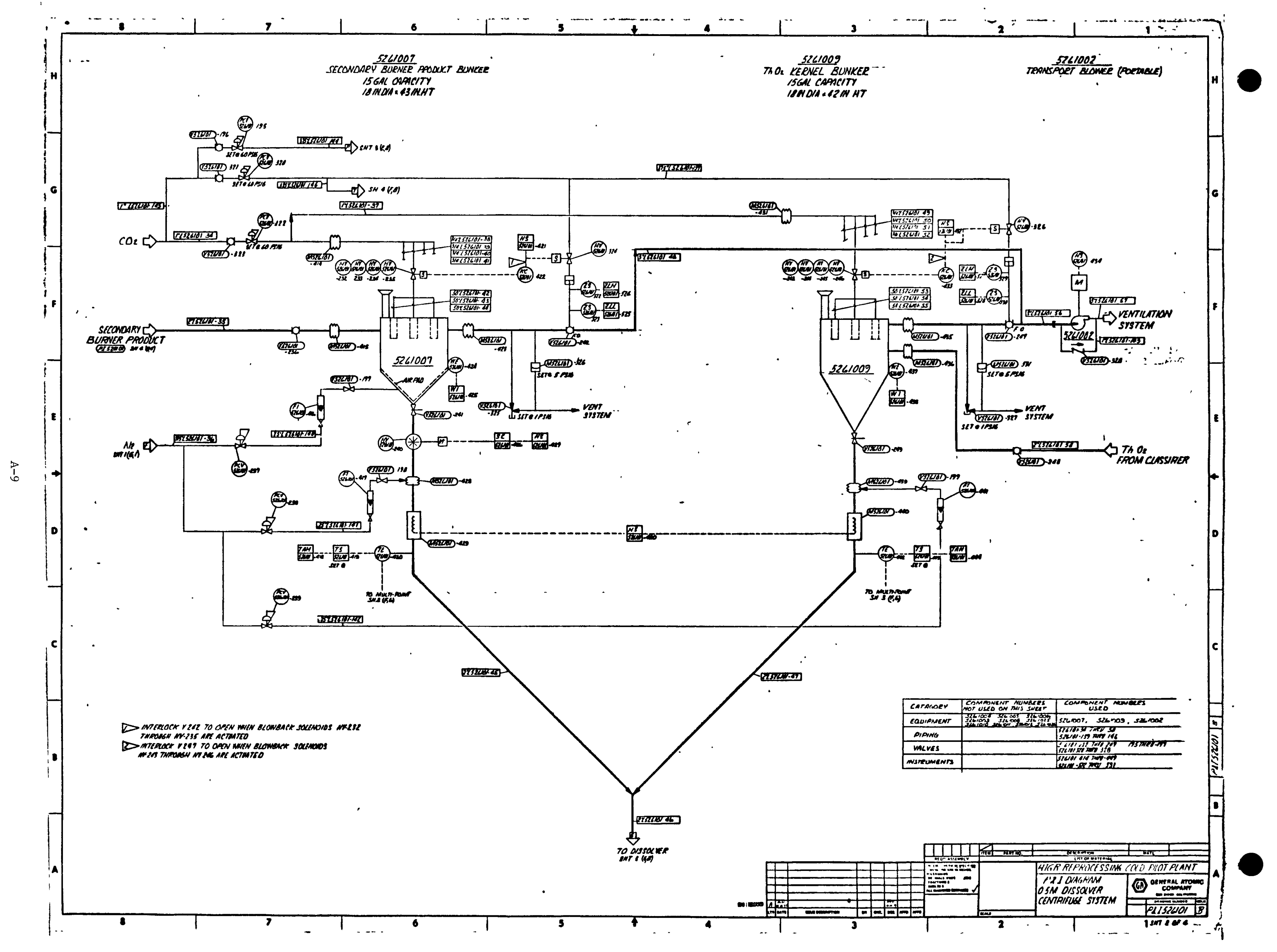


$\bullet$

-

-

- 


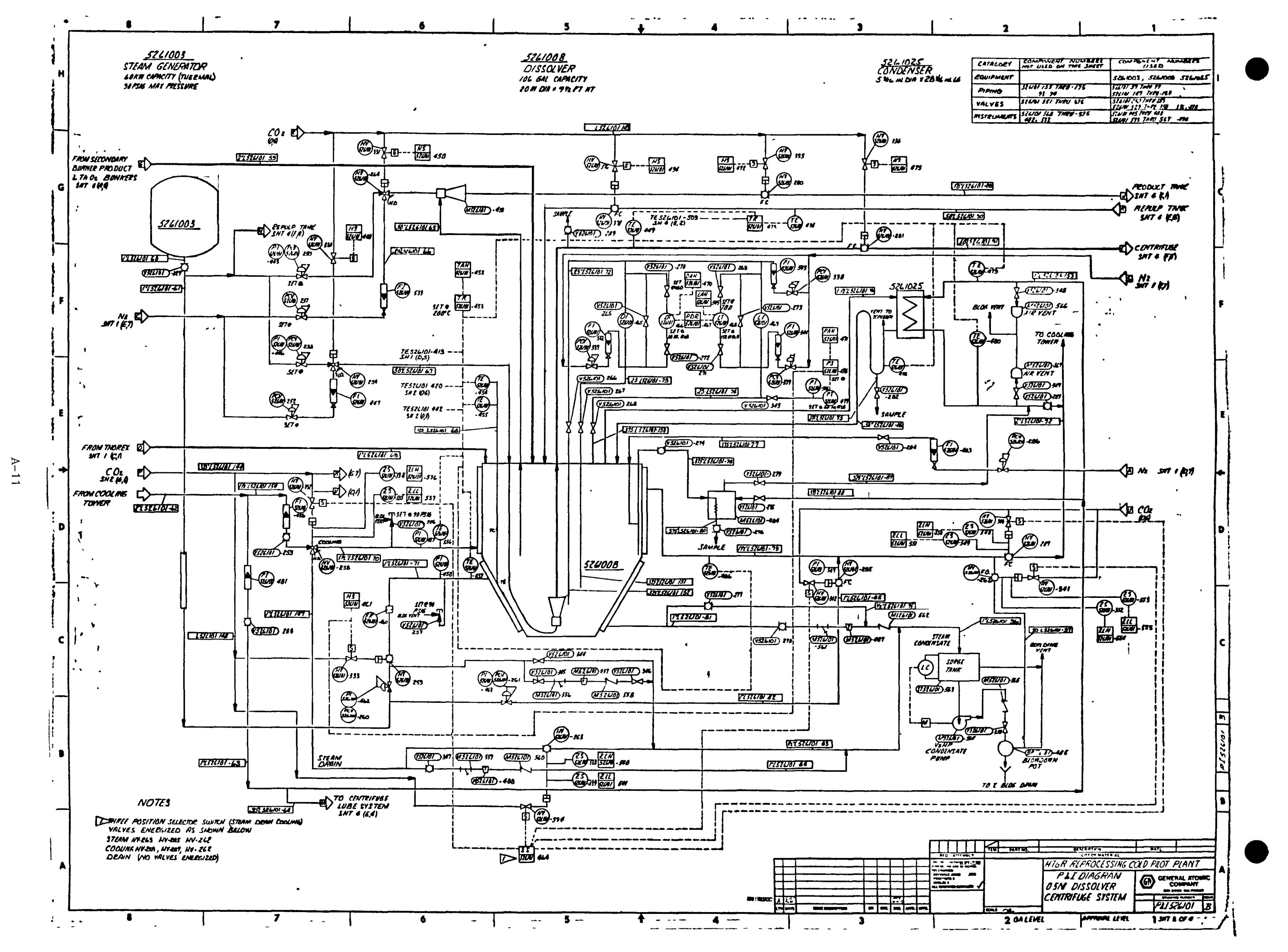


-

- 


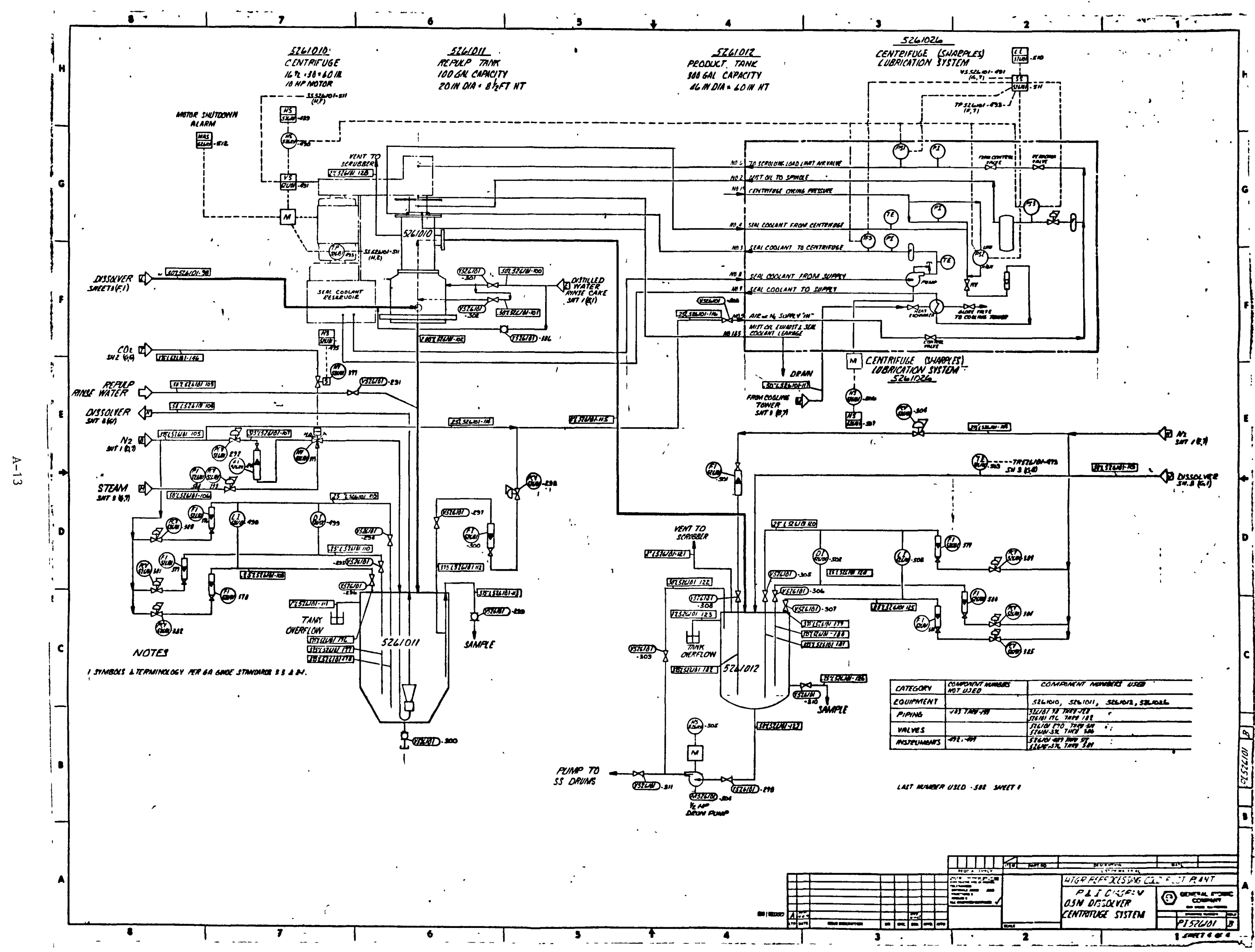


APPENDIX B

MAJOR ASSEMBLY DRAWINGS

B-1 
○

- 


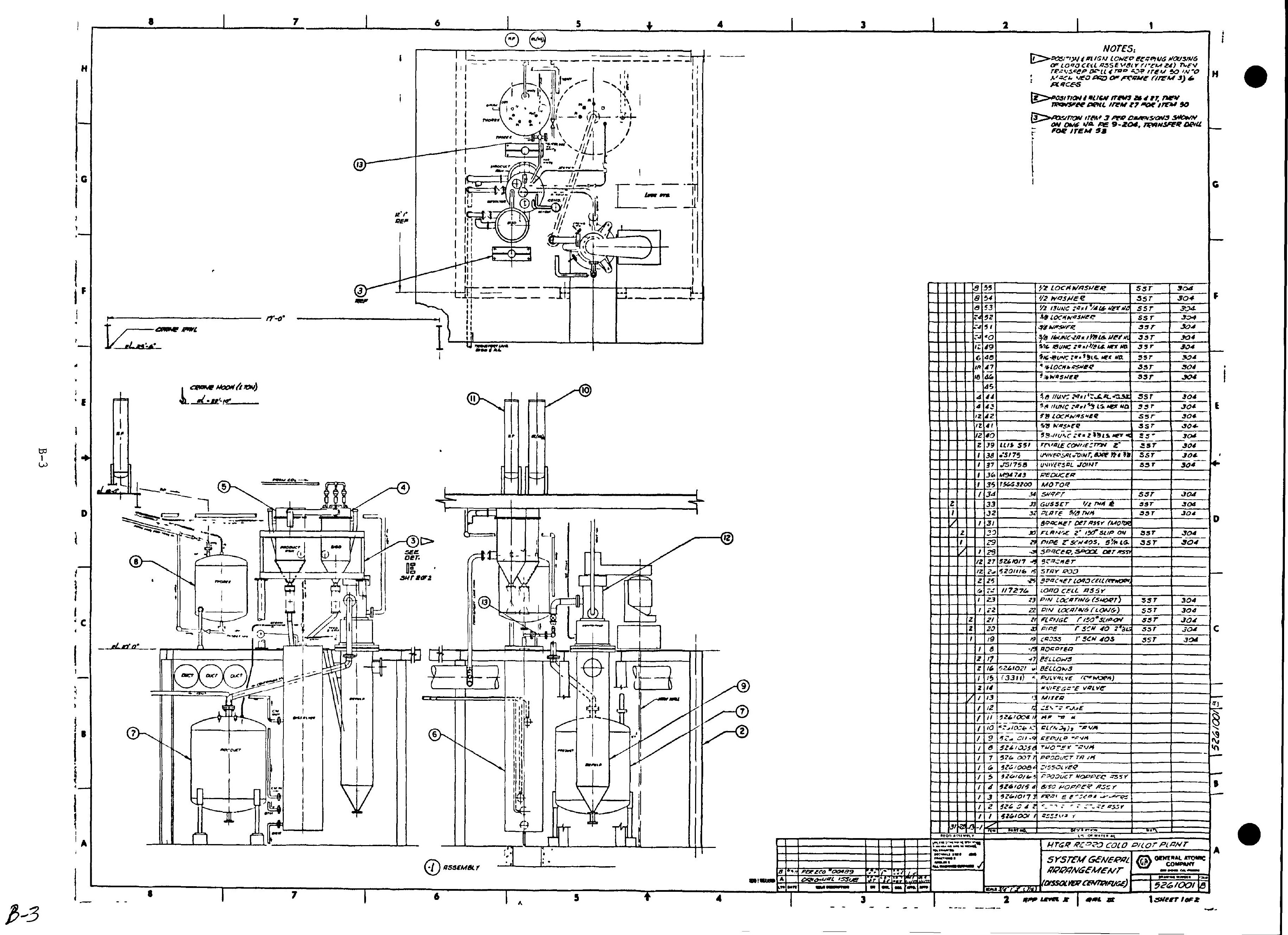


-

- 


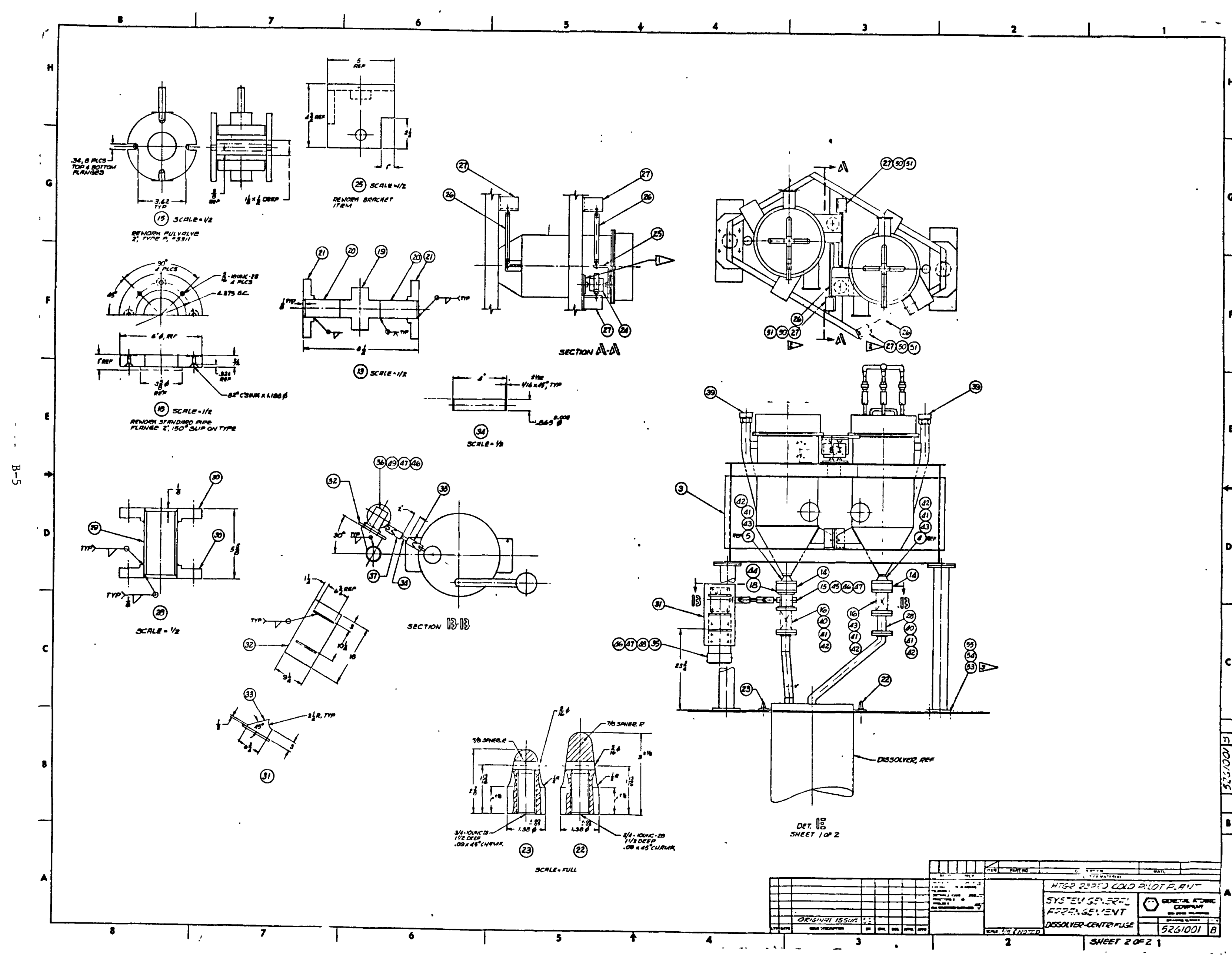


-

( 


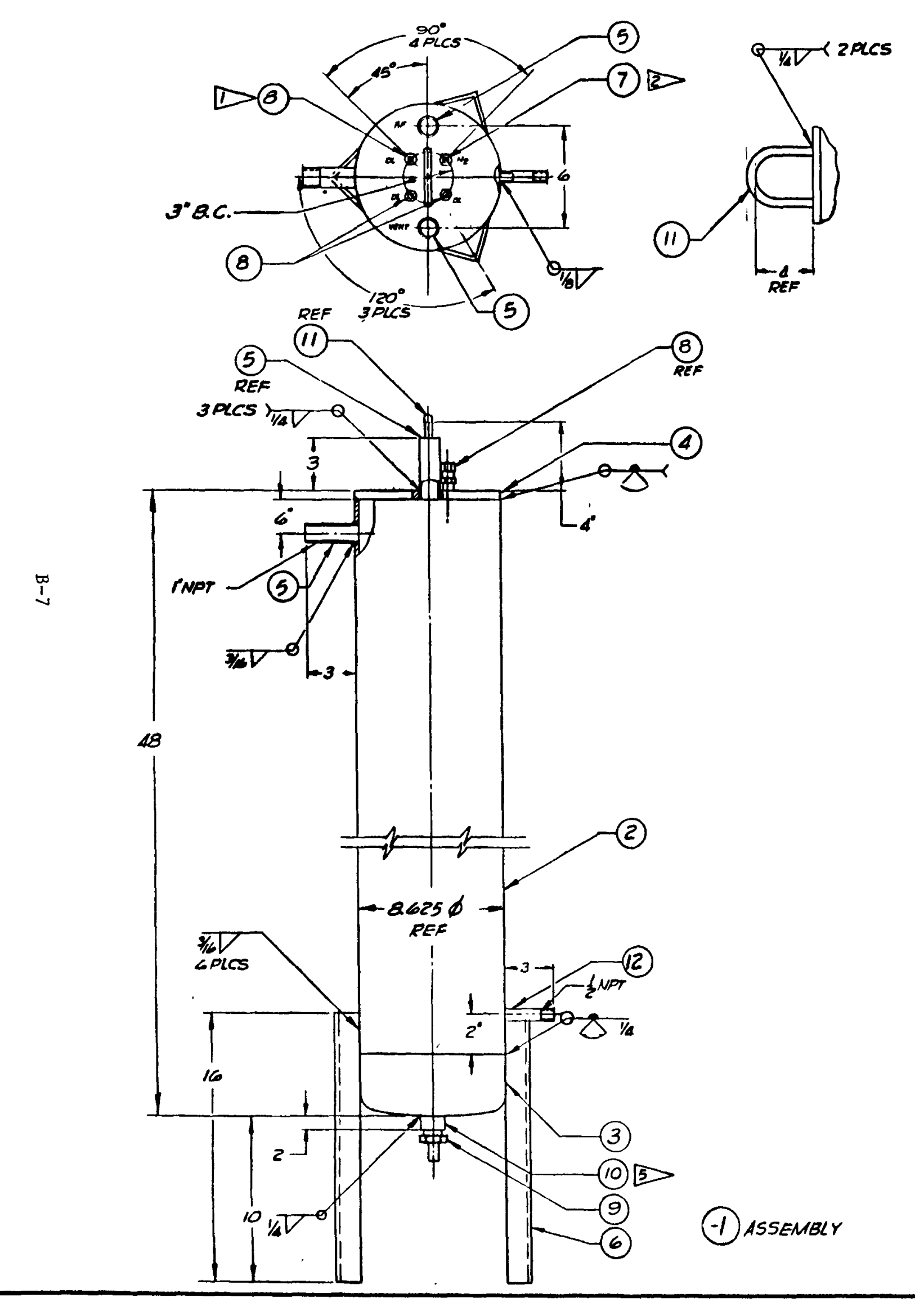

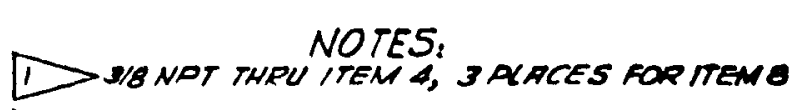
2 IIANPT TNEU ITEM \&, FOR ITEM 7

3. REMOVE BURRS \& SHARP EDGES

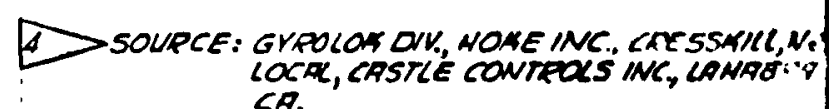
$C A$.

5 SARILL "3I' TNFL I/DNPT

Siall materials invessel to oe 3011

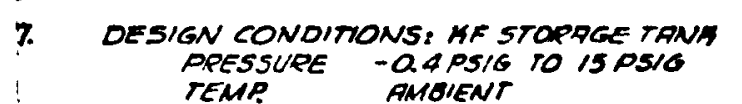

a OMENSIONS \& TOLERANCES DEP ANSI YIA.5

9. WELO BY MANUAL AFE, GMA DP GTA PROCESS

DO SOURCE: LADISH CO, CUDANY, WISCONSIN

11. PENETPANT INSPECT RLL WELOS

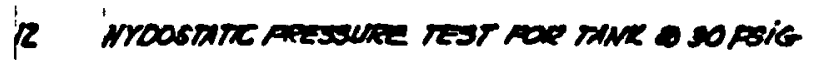
1

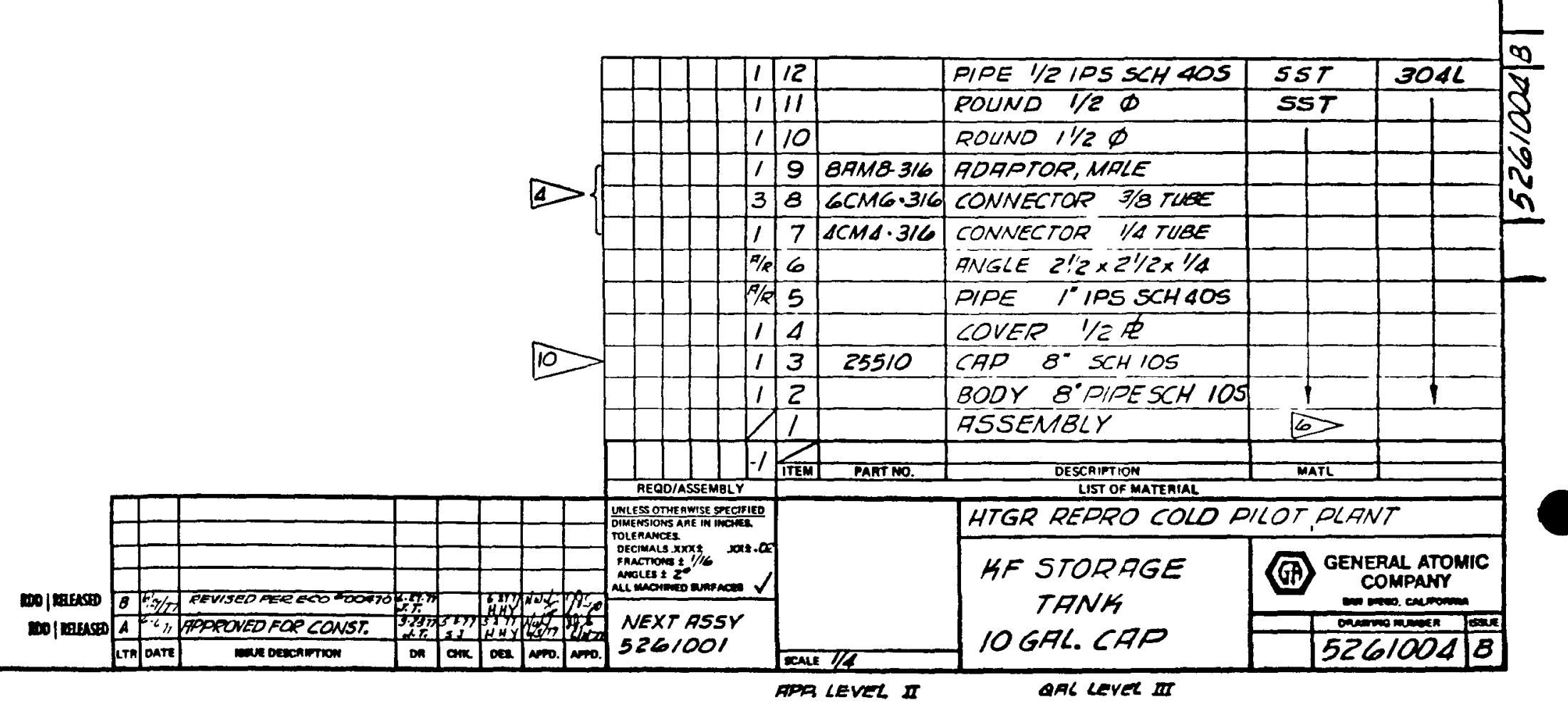


-

•

-

- 


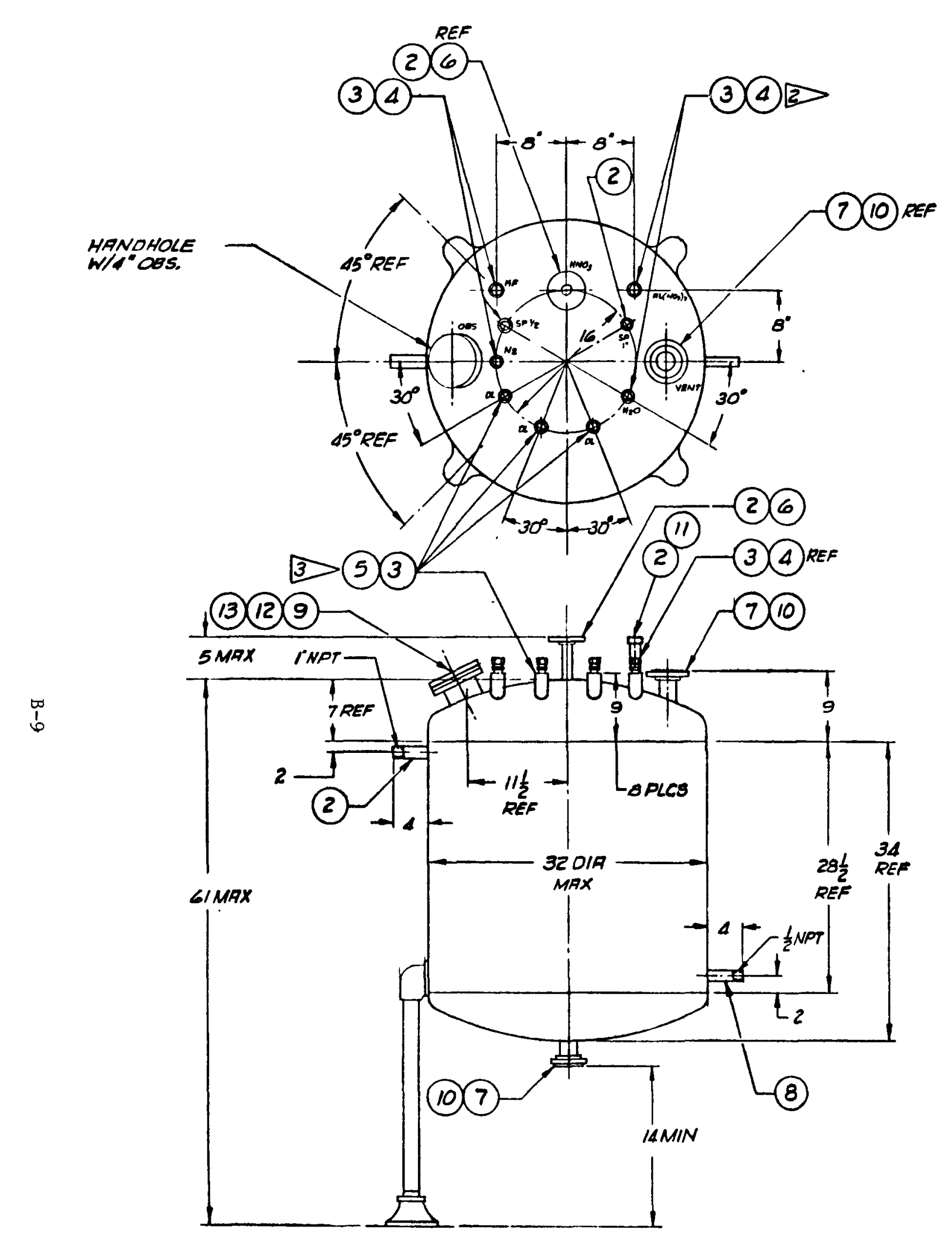

(1) assembly

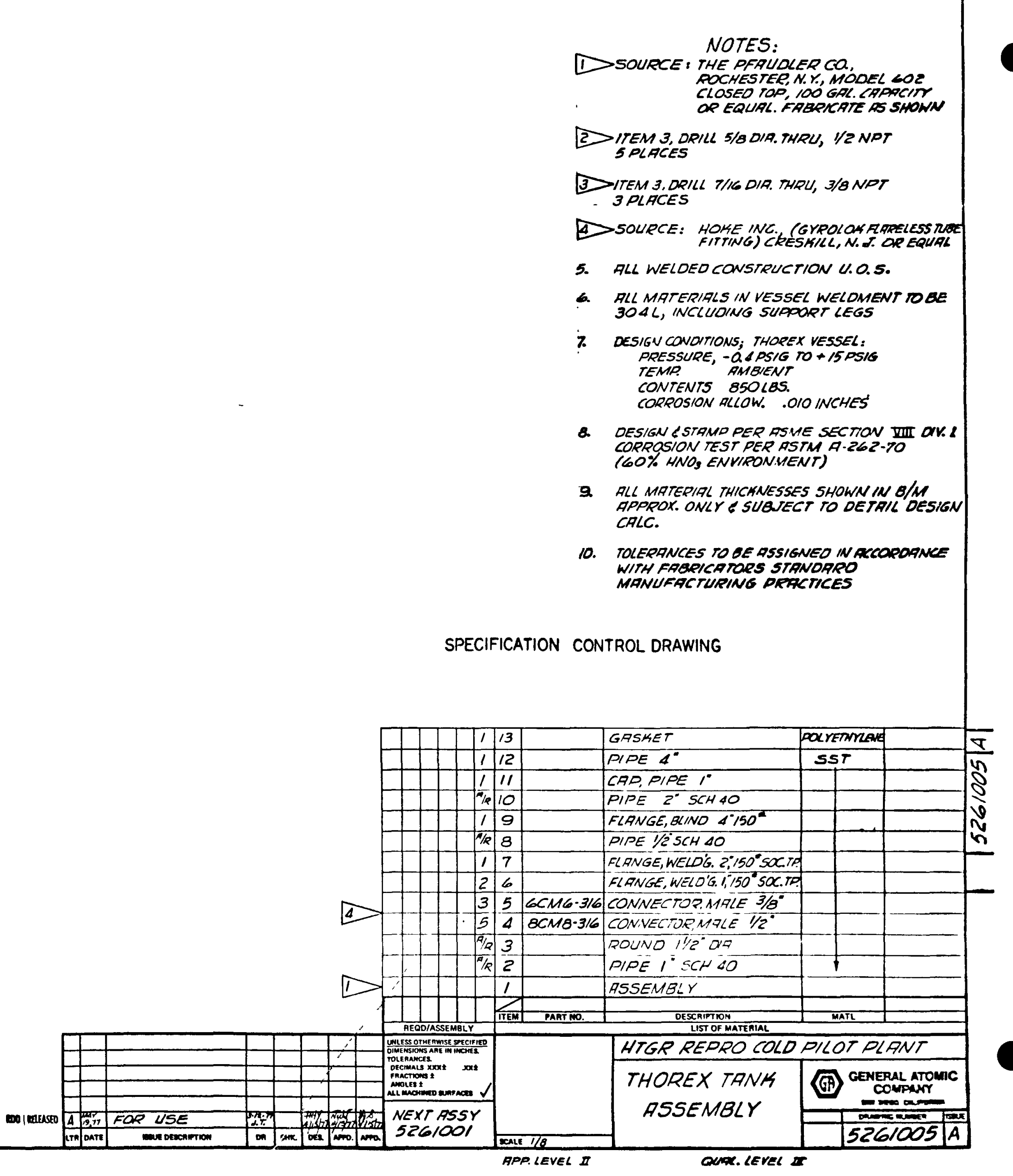




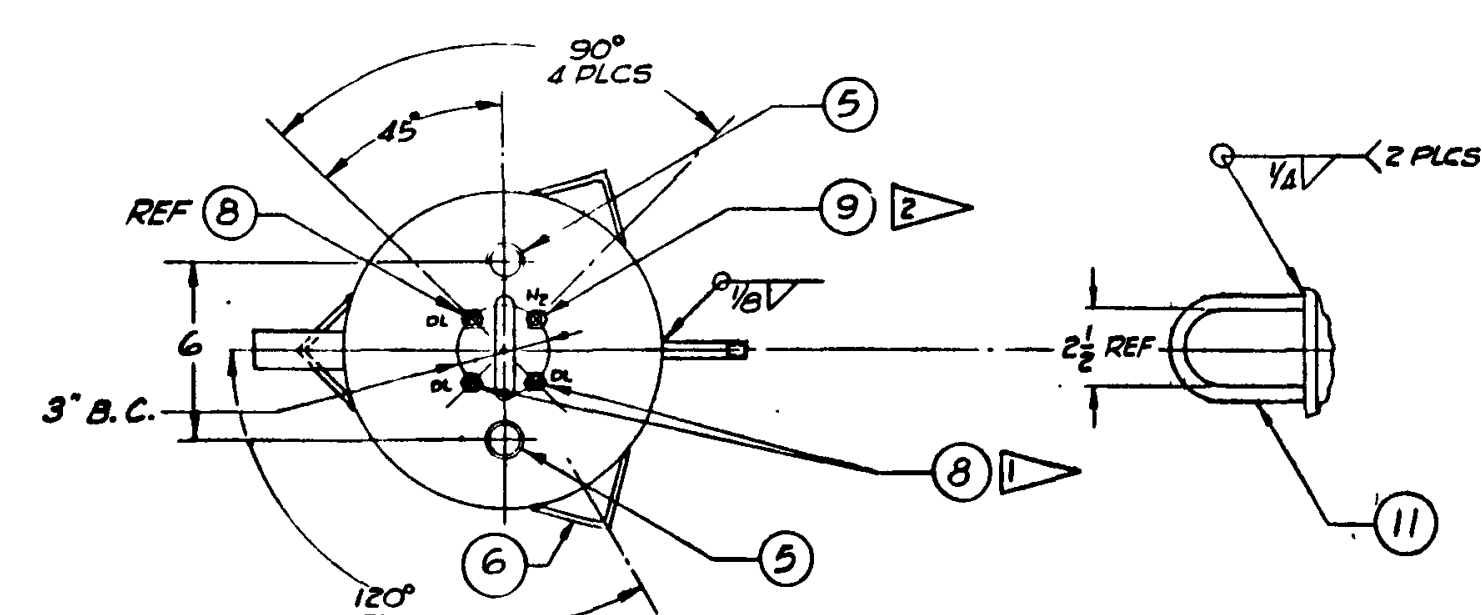

D3/8NPT THRUITEM A, 3 PLACES FOPITEM O 2 IIA NPT THRU ITEM A, FOR ITEM I

3. REMOVE BURRS \& SHARP EDGES

4 SOURCE: GYEOLOK OIV, HOKE INC. CRESSHML INC.', $\angle A H B B P A, \angle A$.

5 ORILL 23/3Q THRU, IINNPT

6 ALL MATERIALS IN VESSEL TO BE $302 L$

7. DESIGN CONOITONS: ALNOS), STORAGE TAMN

DESEN CORSURE -O.APSIS TO + 15 PSIG
TEMP.

B SOURCE: LADISH CO, CUDAHY, WISCONSIN

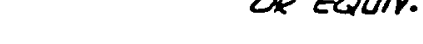

9. DIMENSIONS / TOLERANCES PER ANSI YIA.5

10. WELO BY MANUIDL RTC, GMA OR GTA PROCCESS

11. PENETRANT INSDECT ALL WELOS

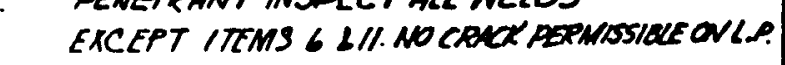

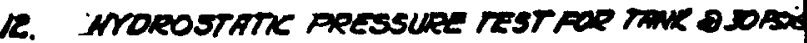

$\stackrel{\text { I }}{=}$

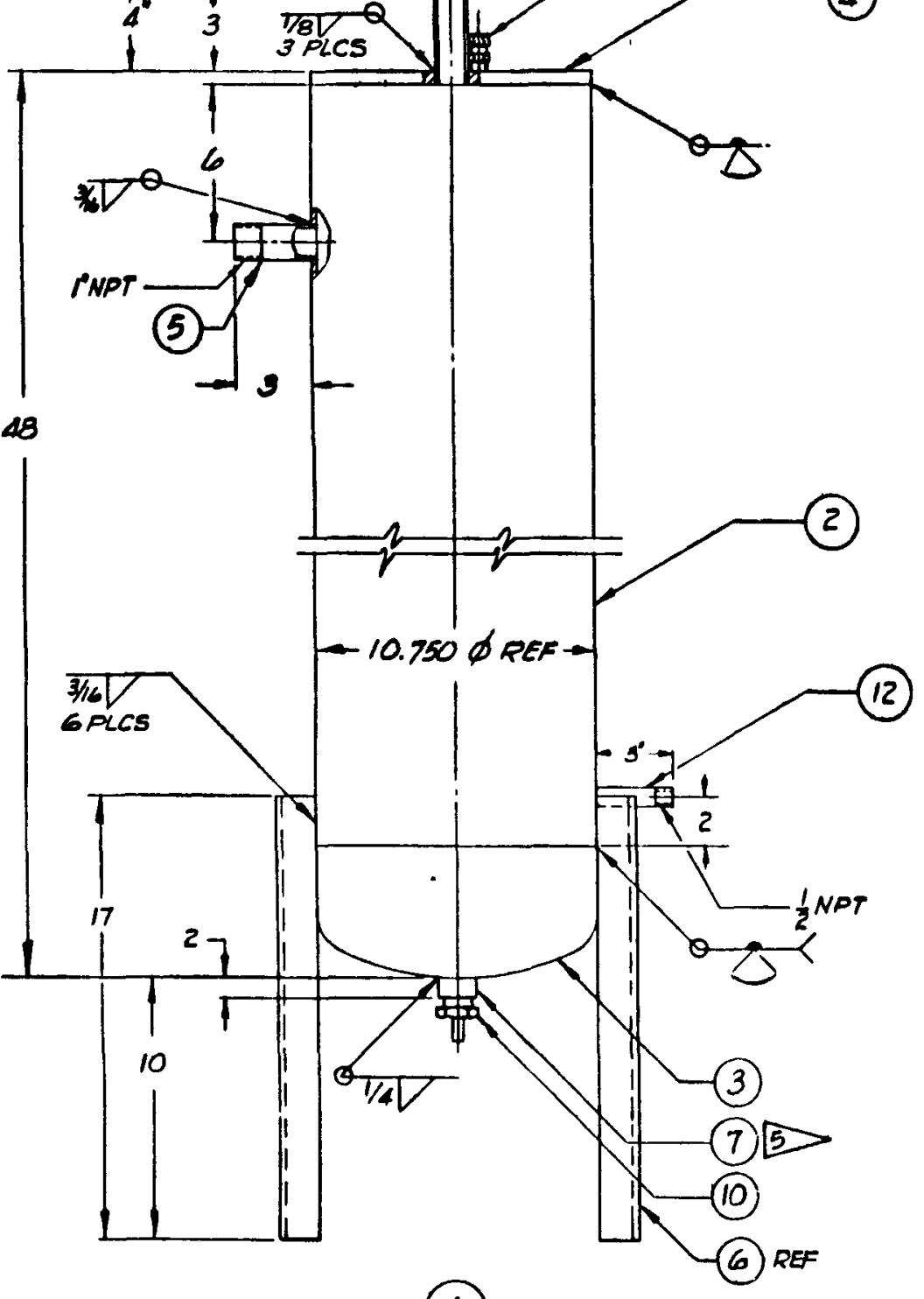

(1) assembLY

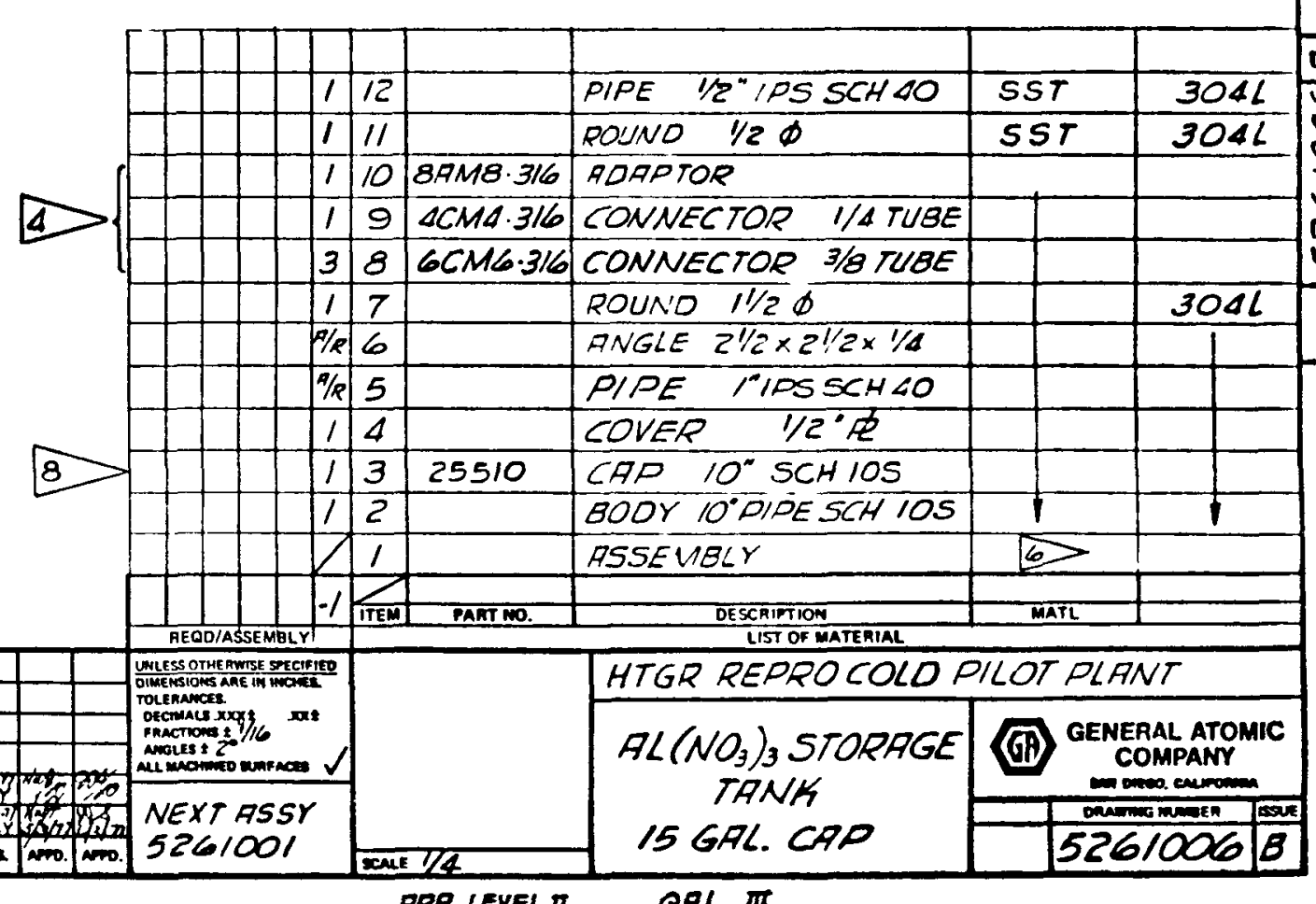




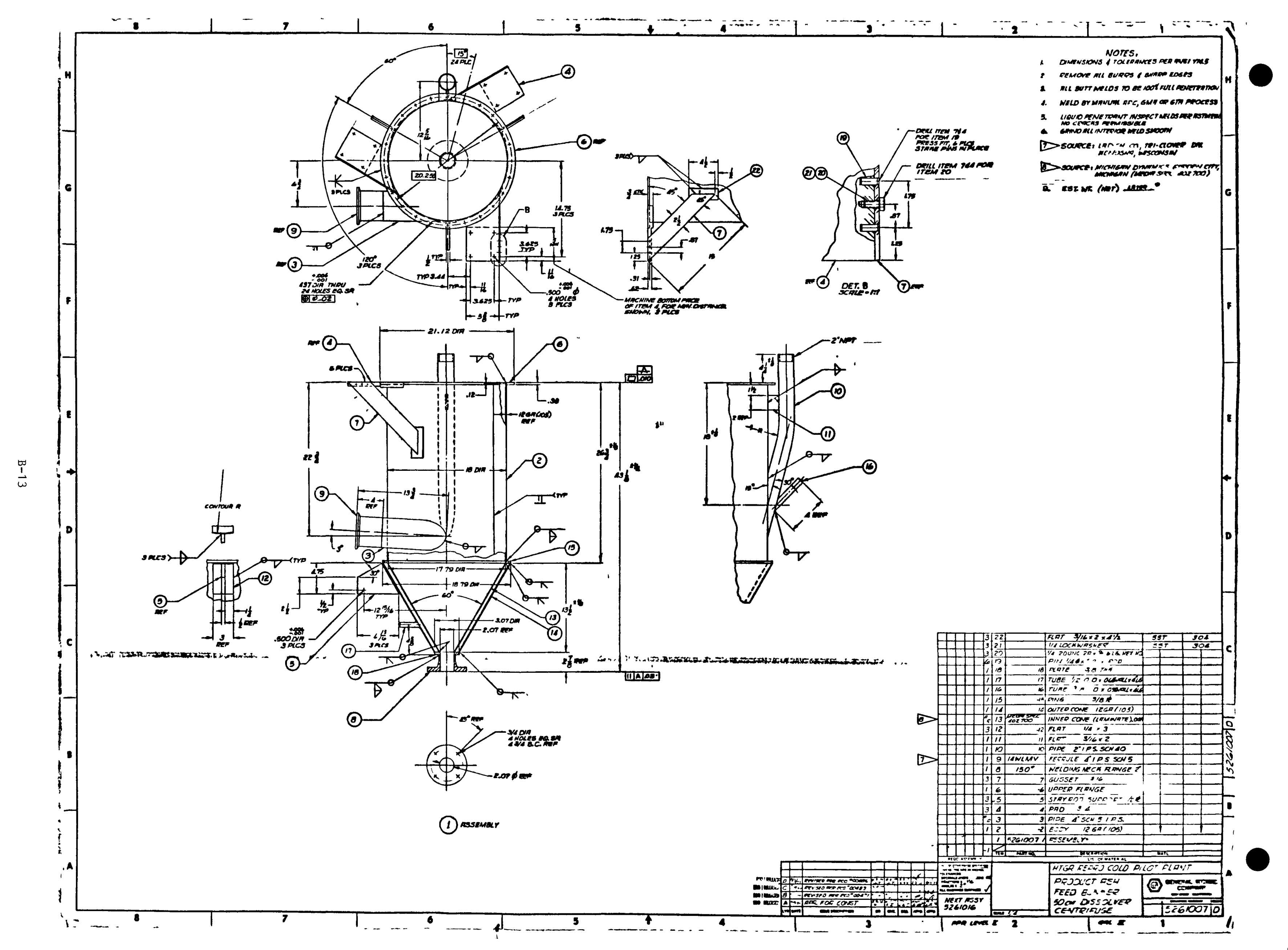


•

-

○. . . 1 0 





-

- 


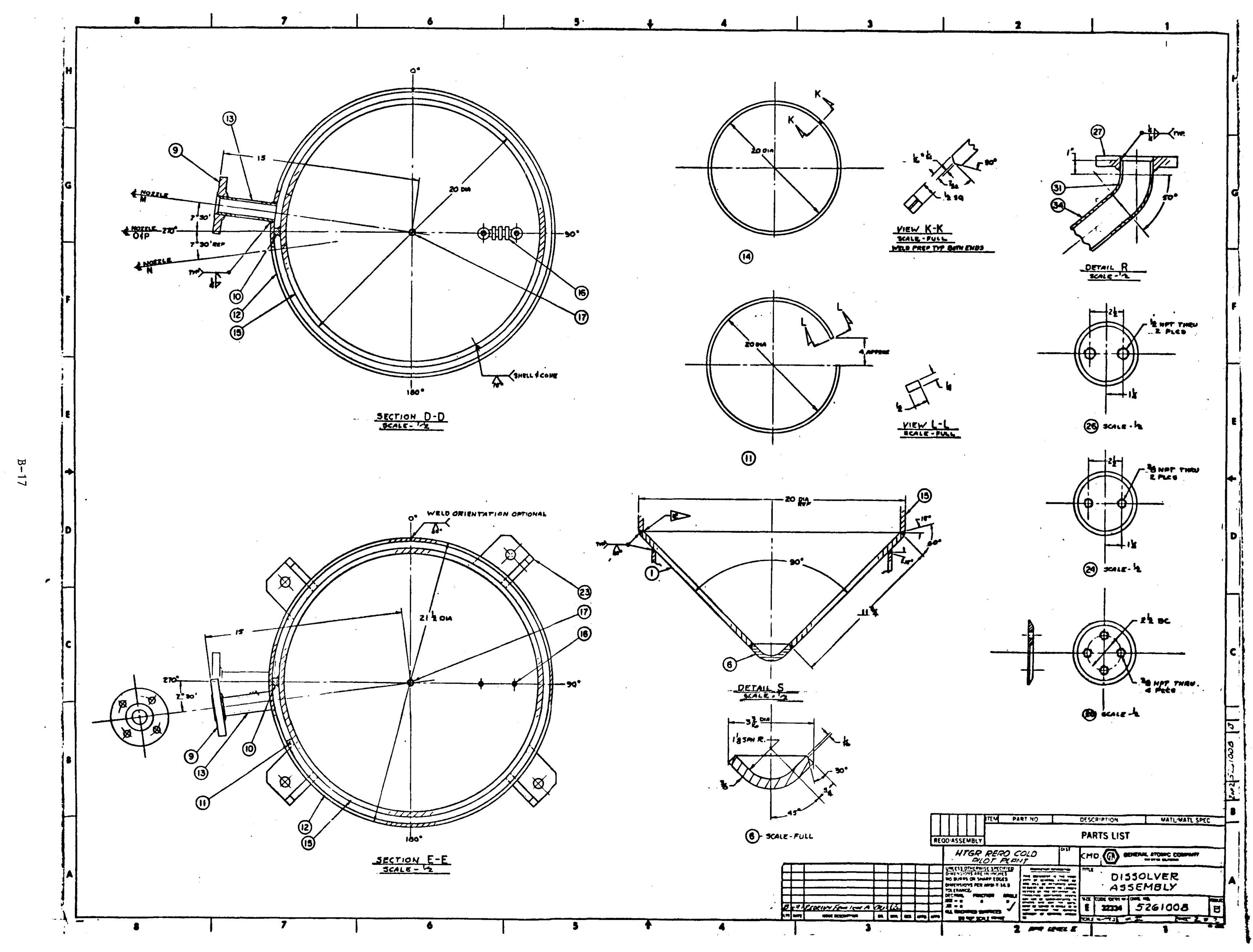


-

- 


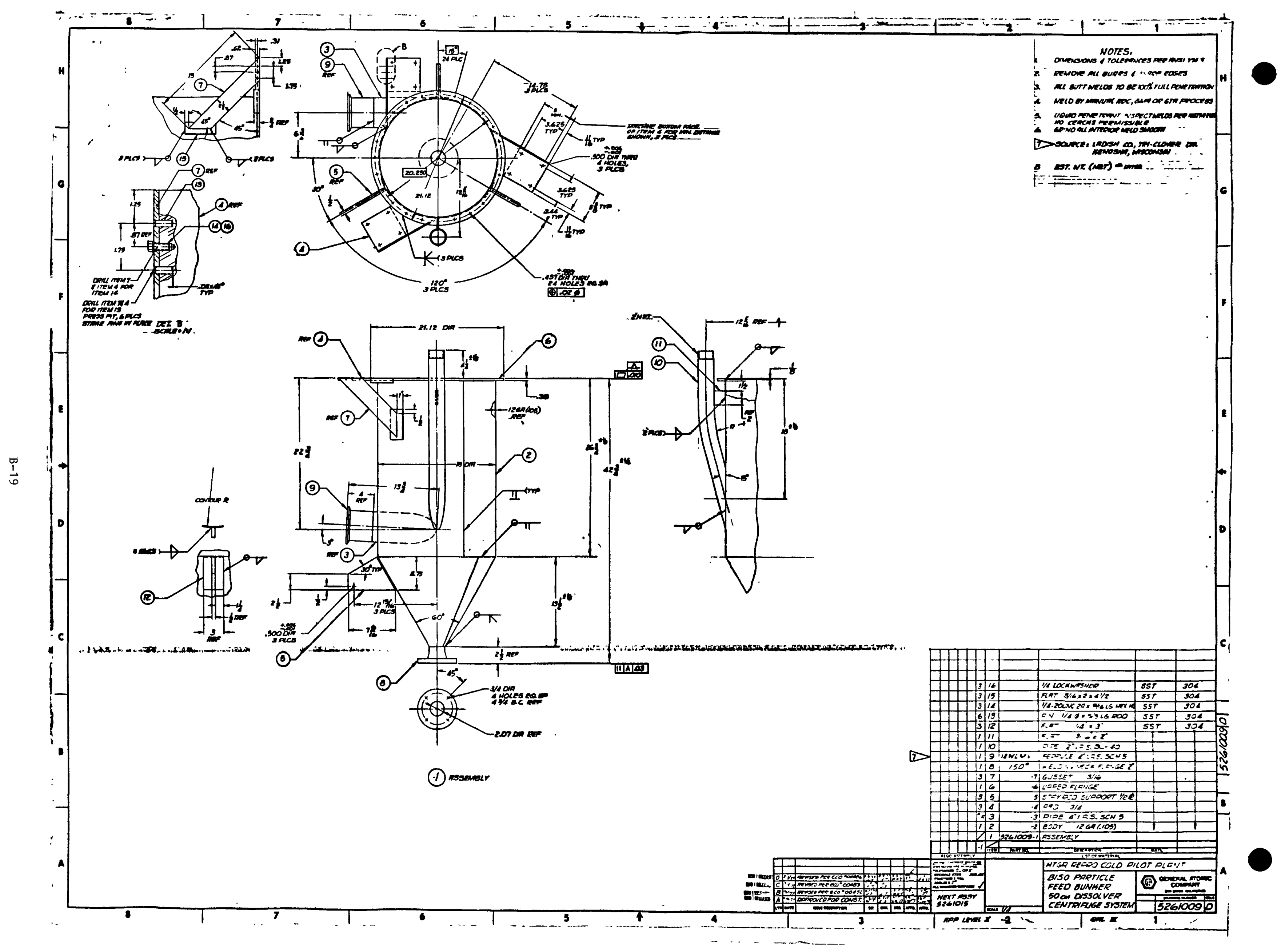




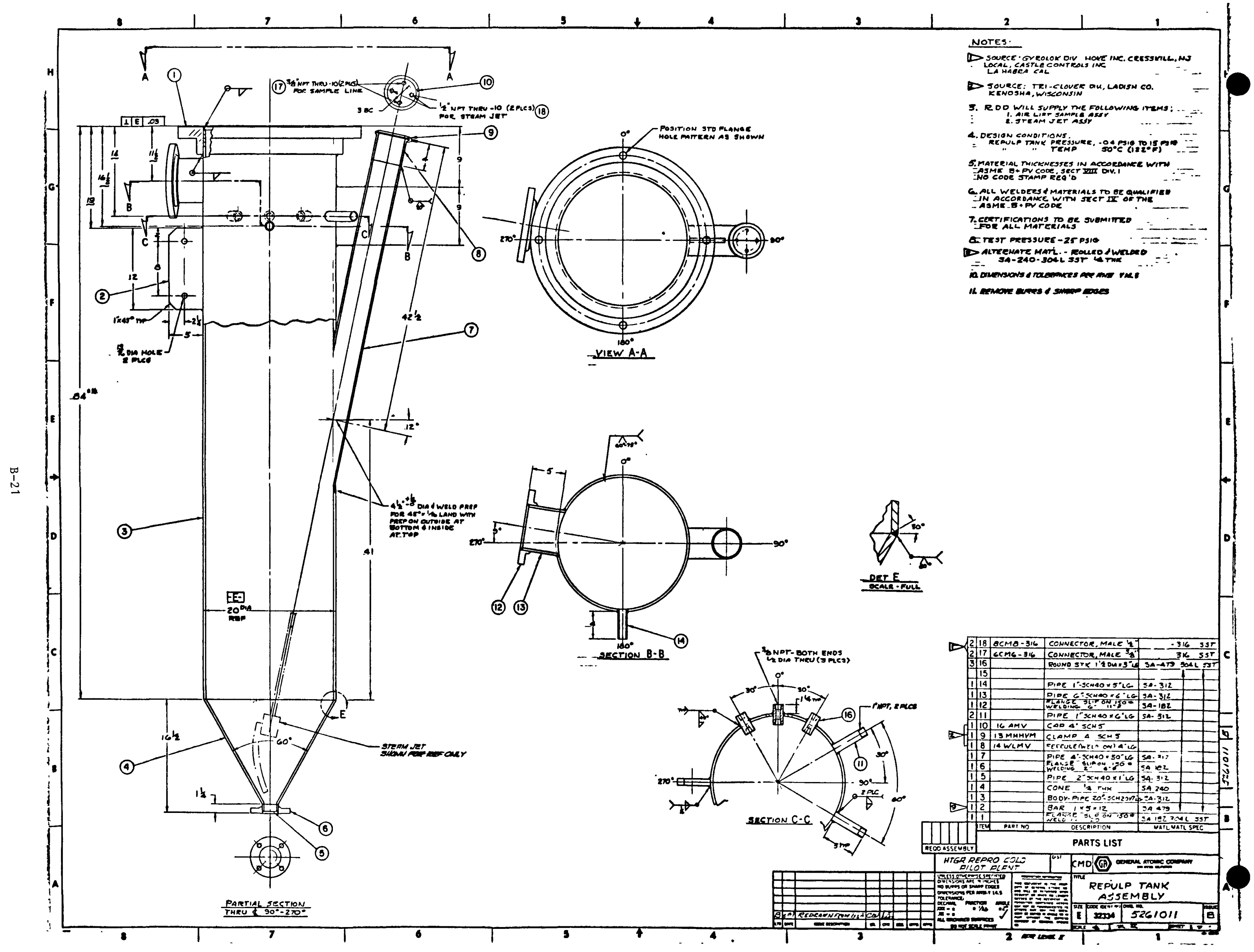


-

-

-

- 


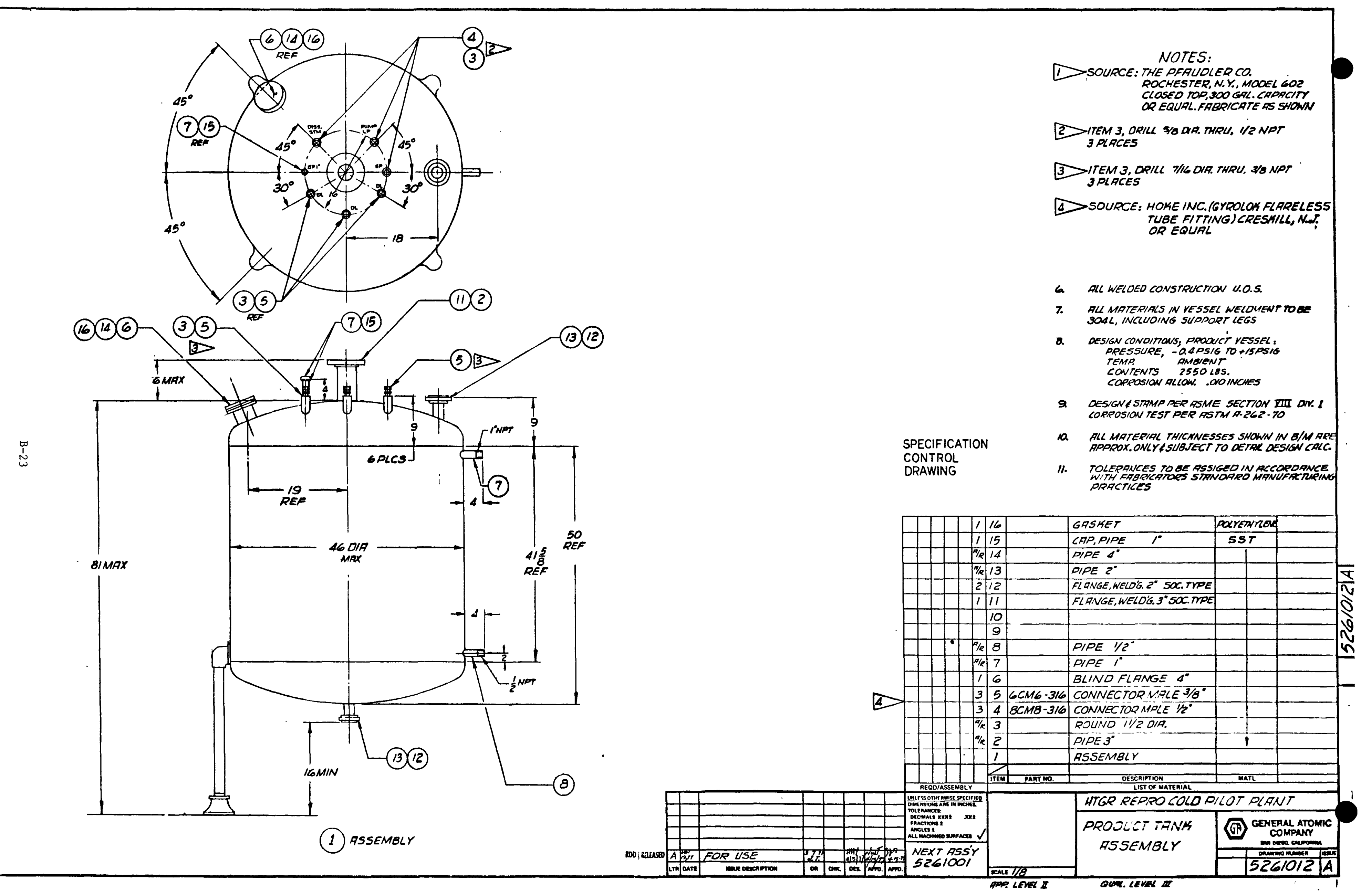


-

-

-

- 


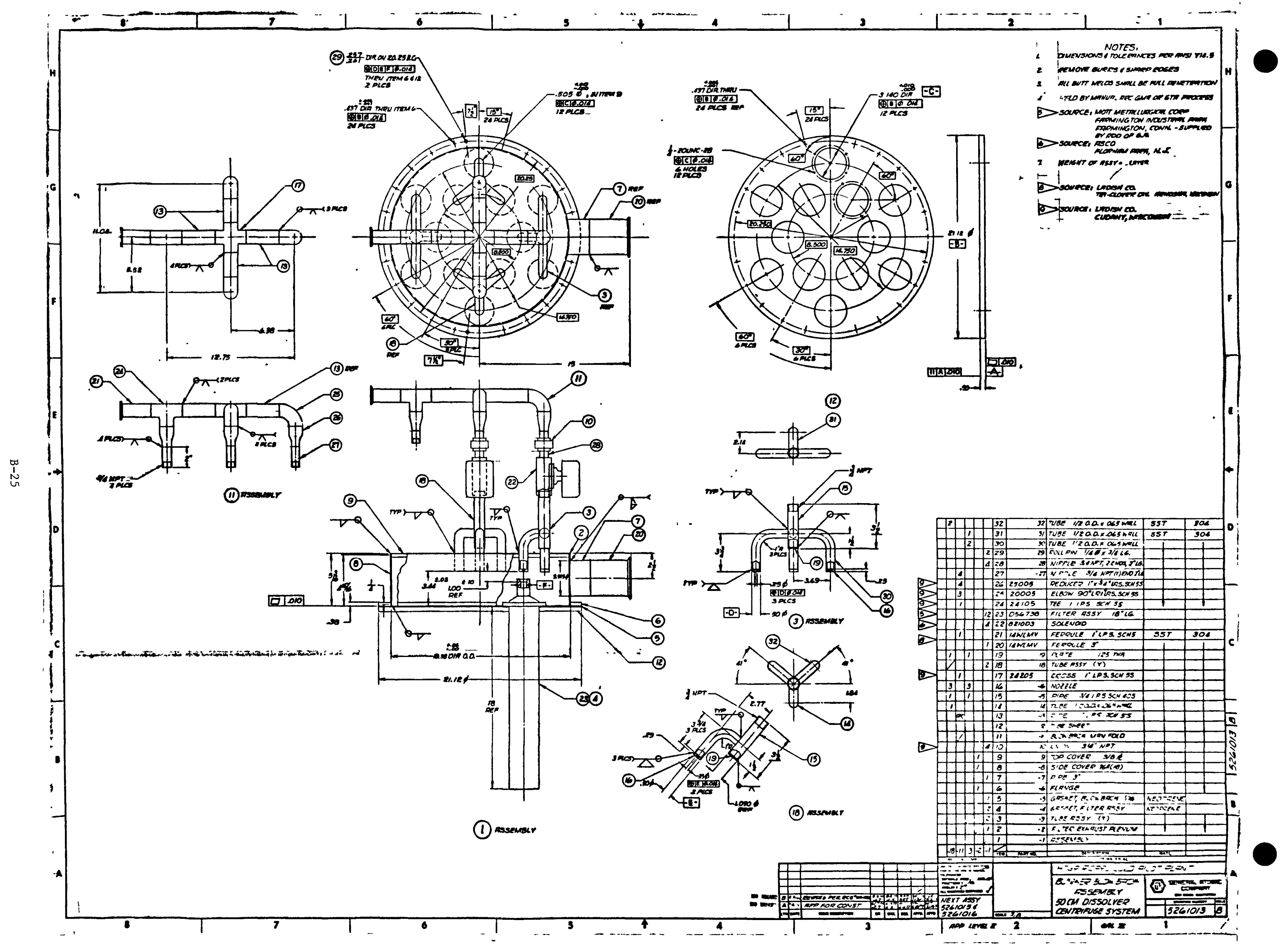


• $\quad \bullet$ 


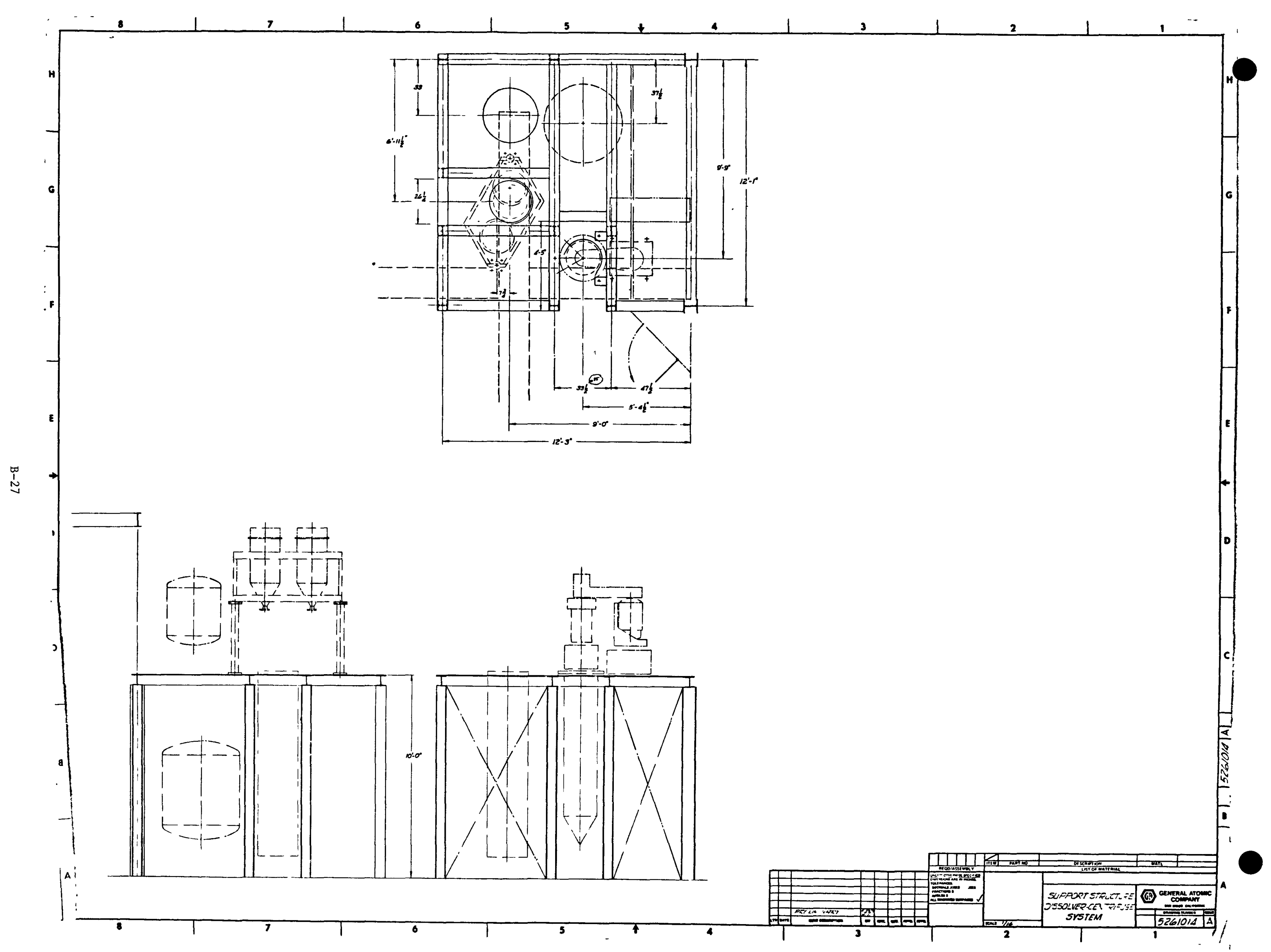




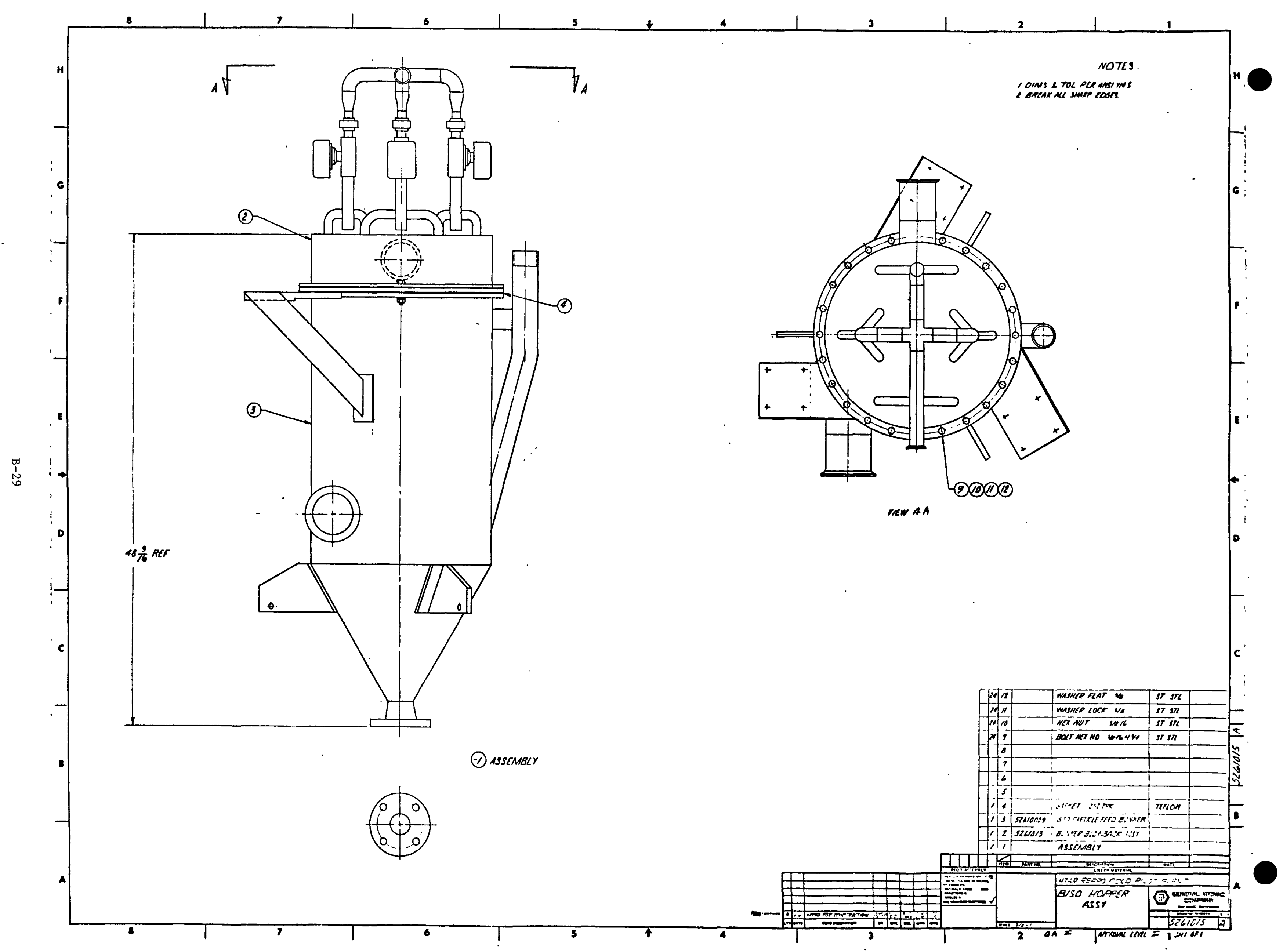




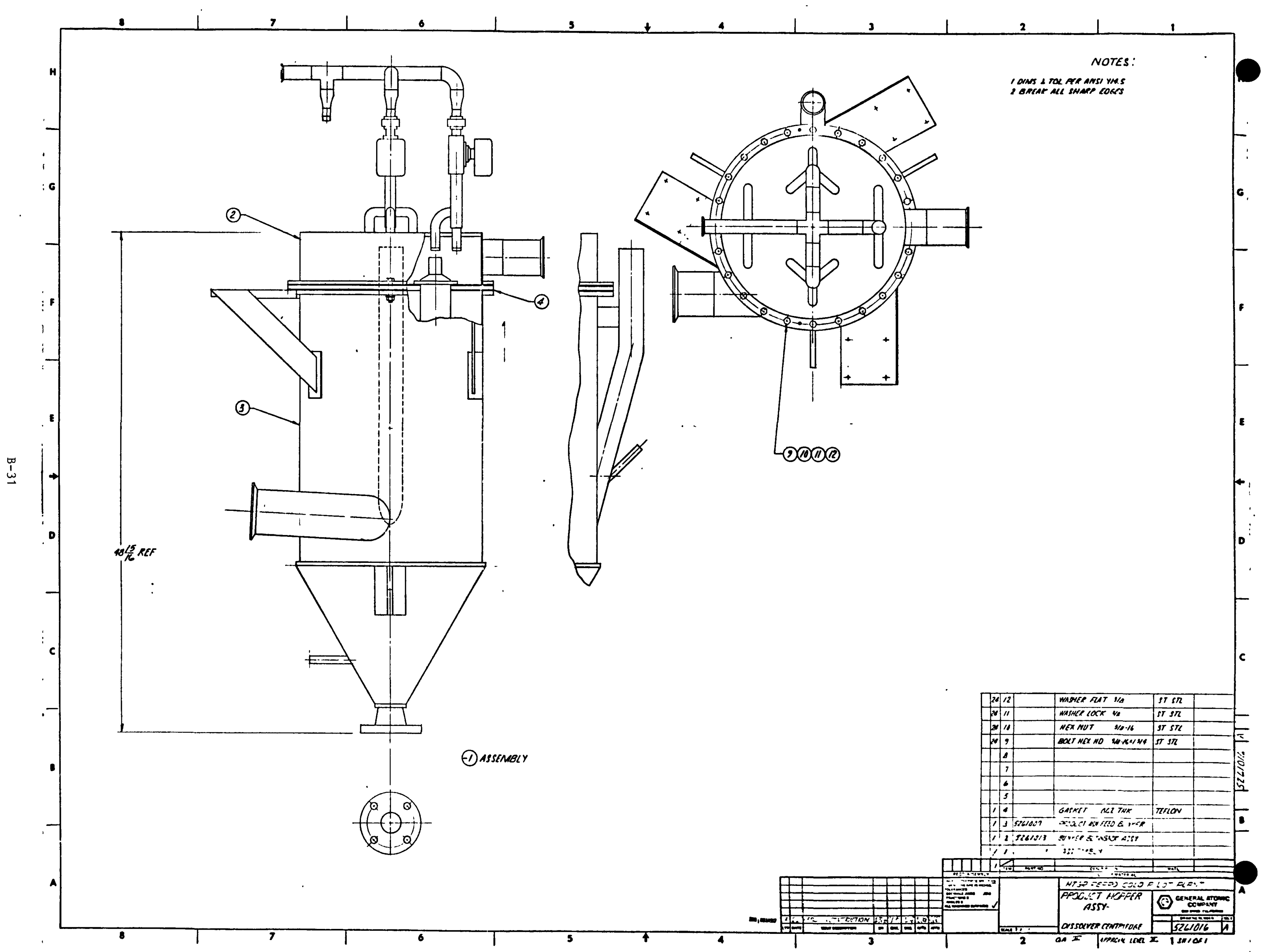


- 


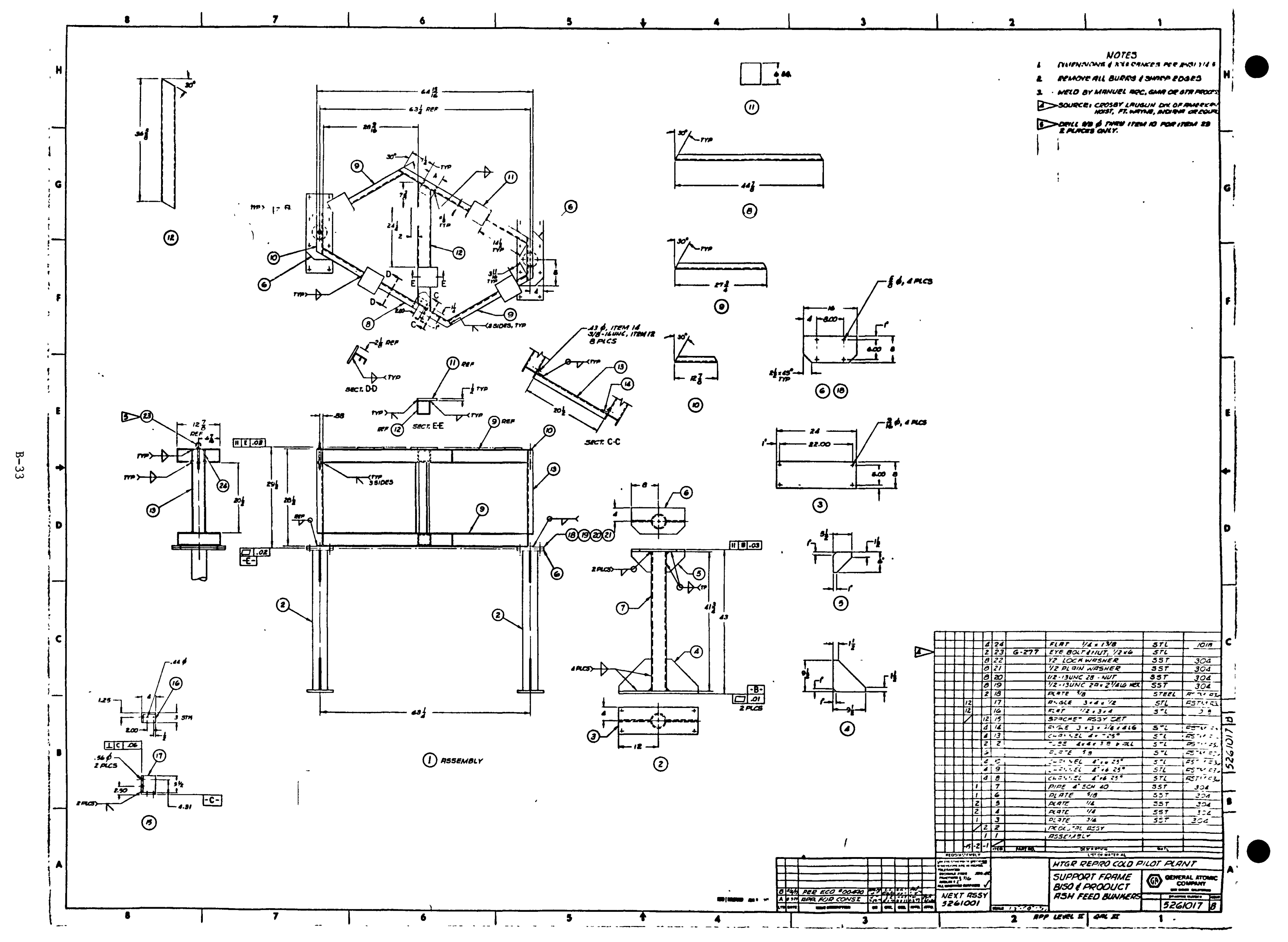


$\bullet$

- 


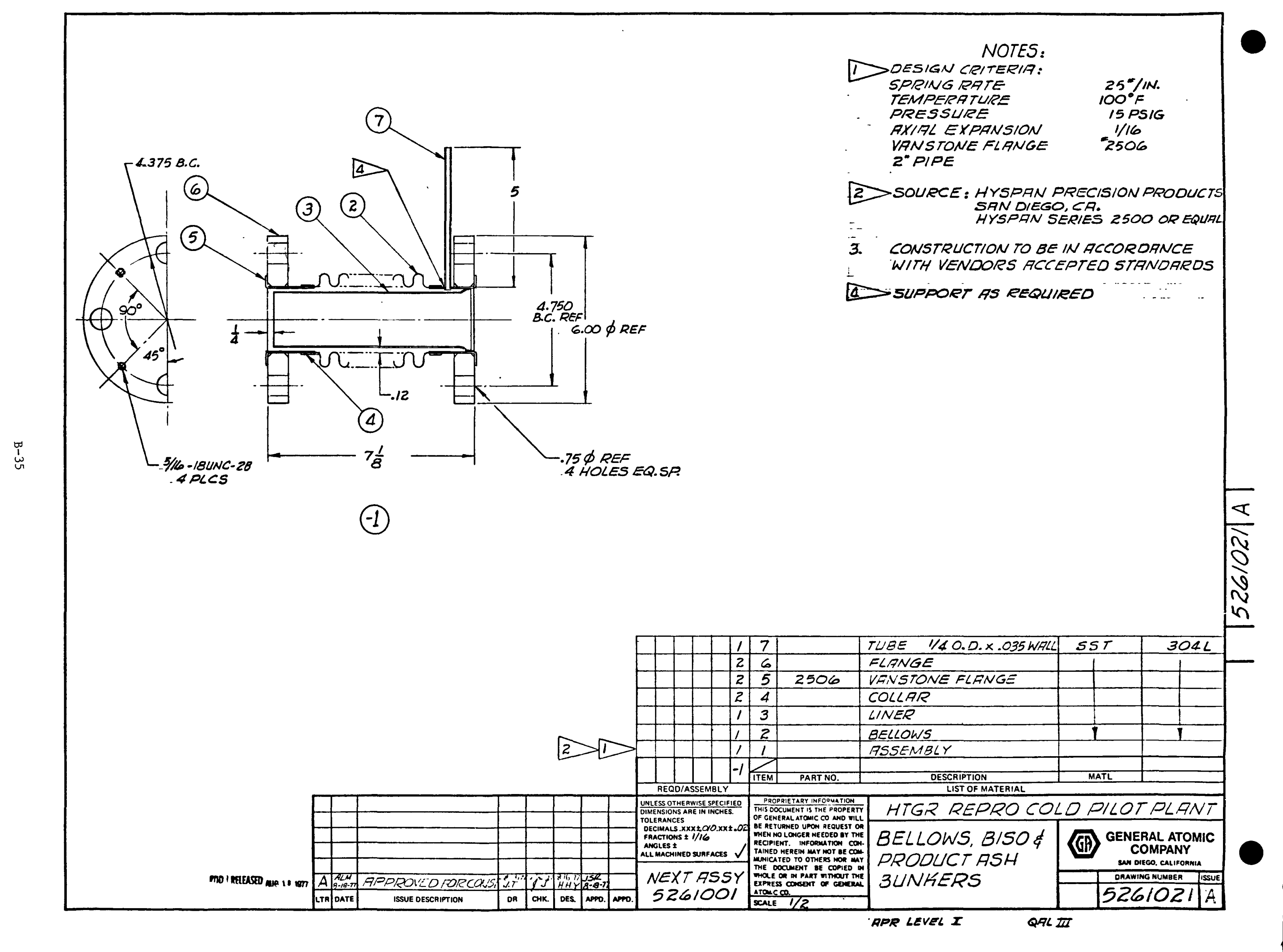


-

-

•

- 


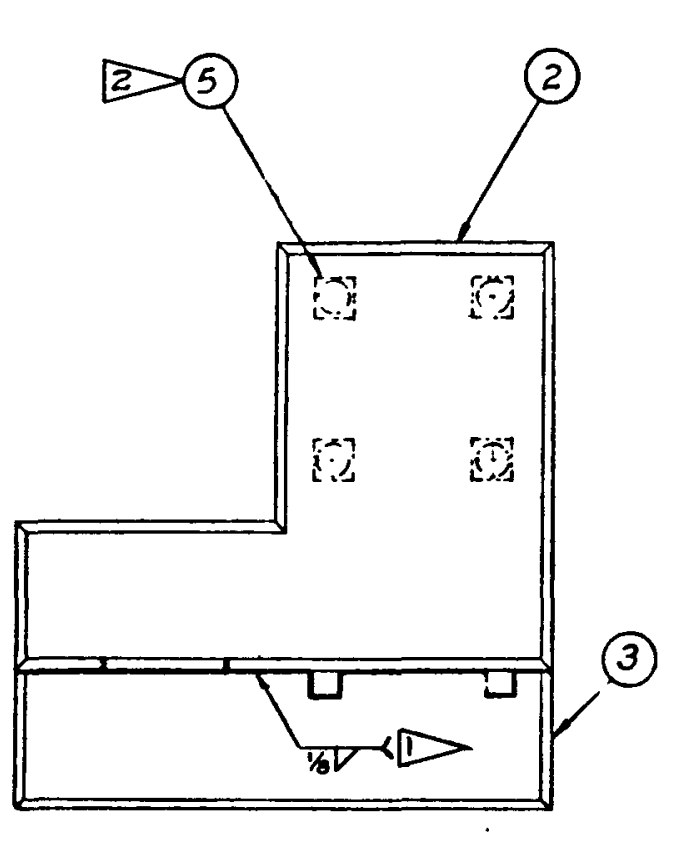

(1)

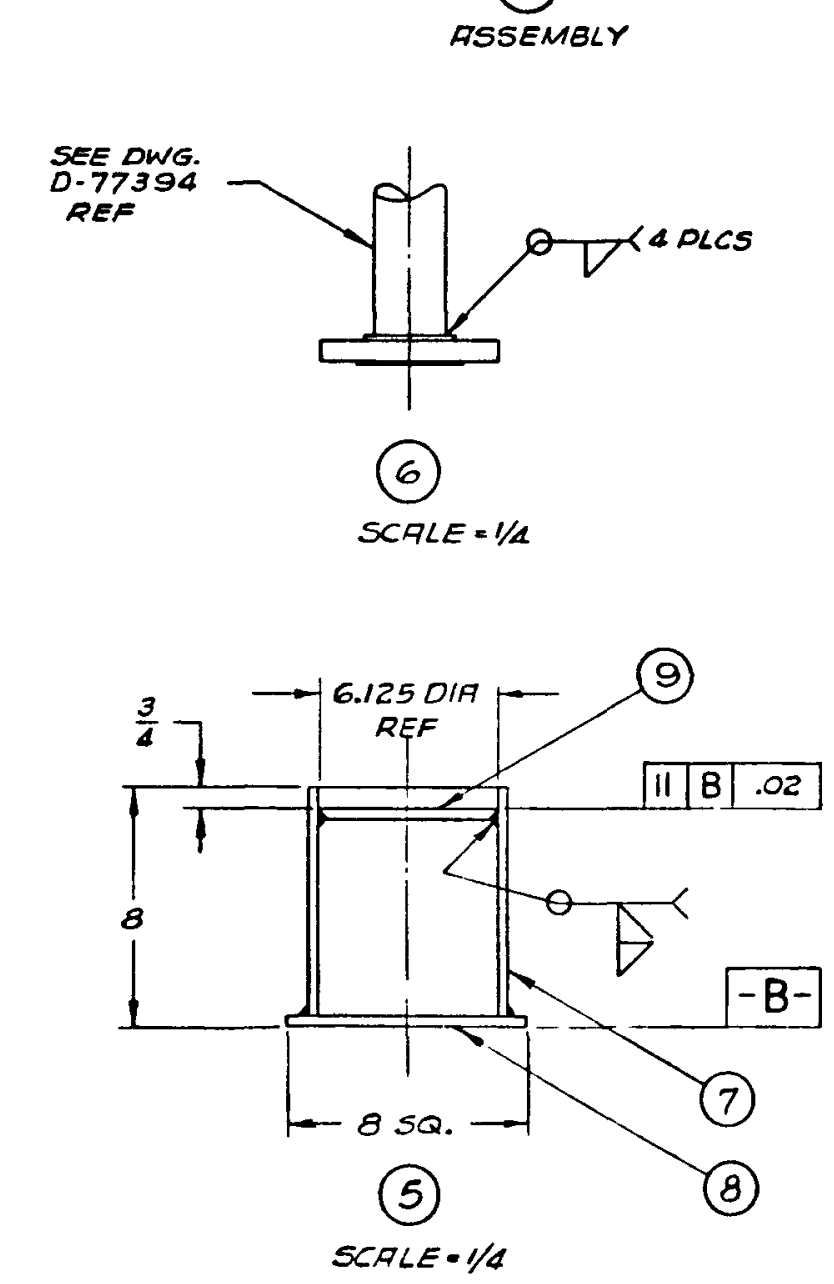

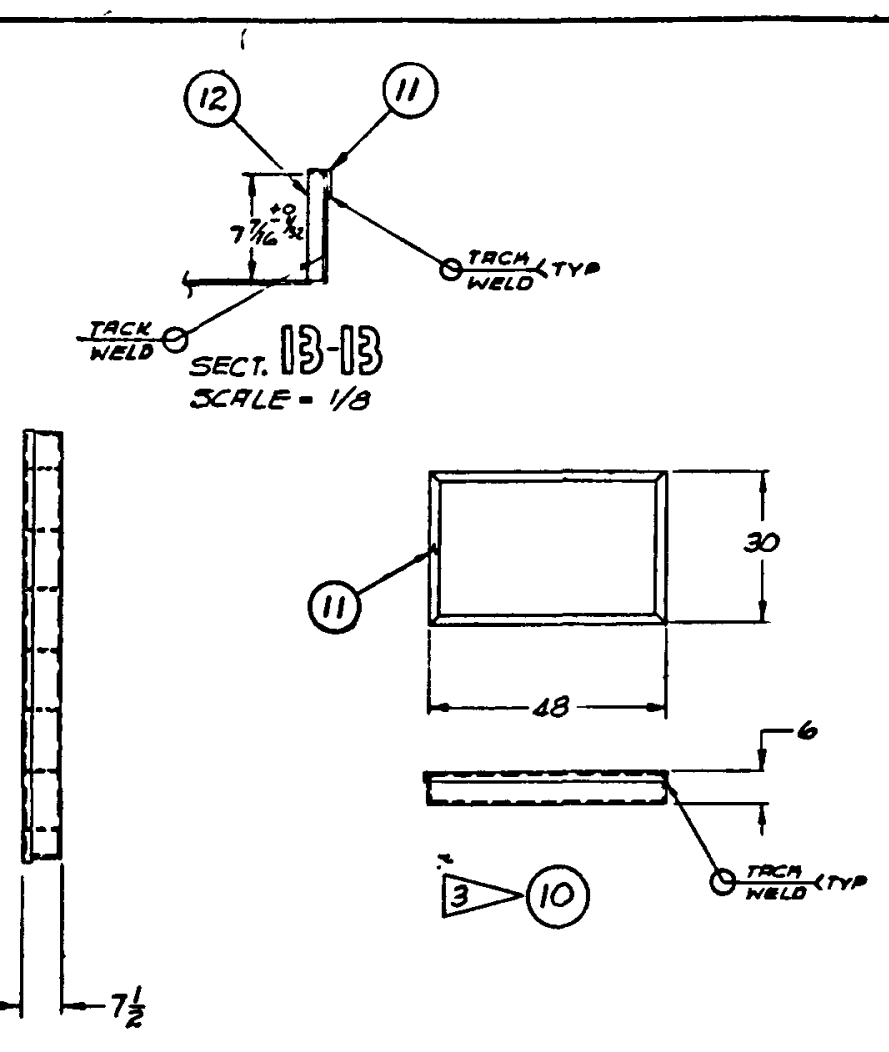

SLET THEU
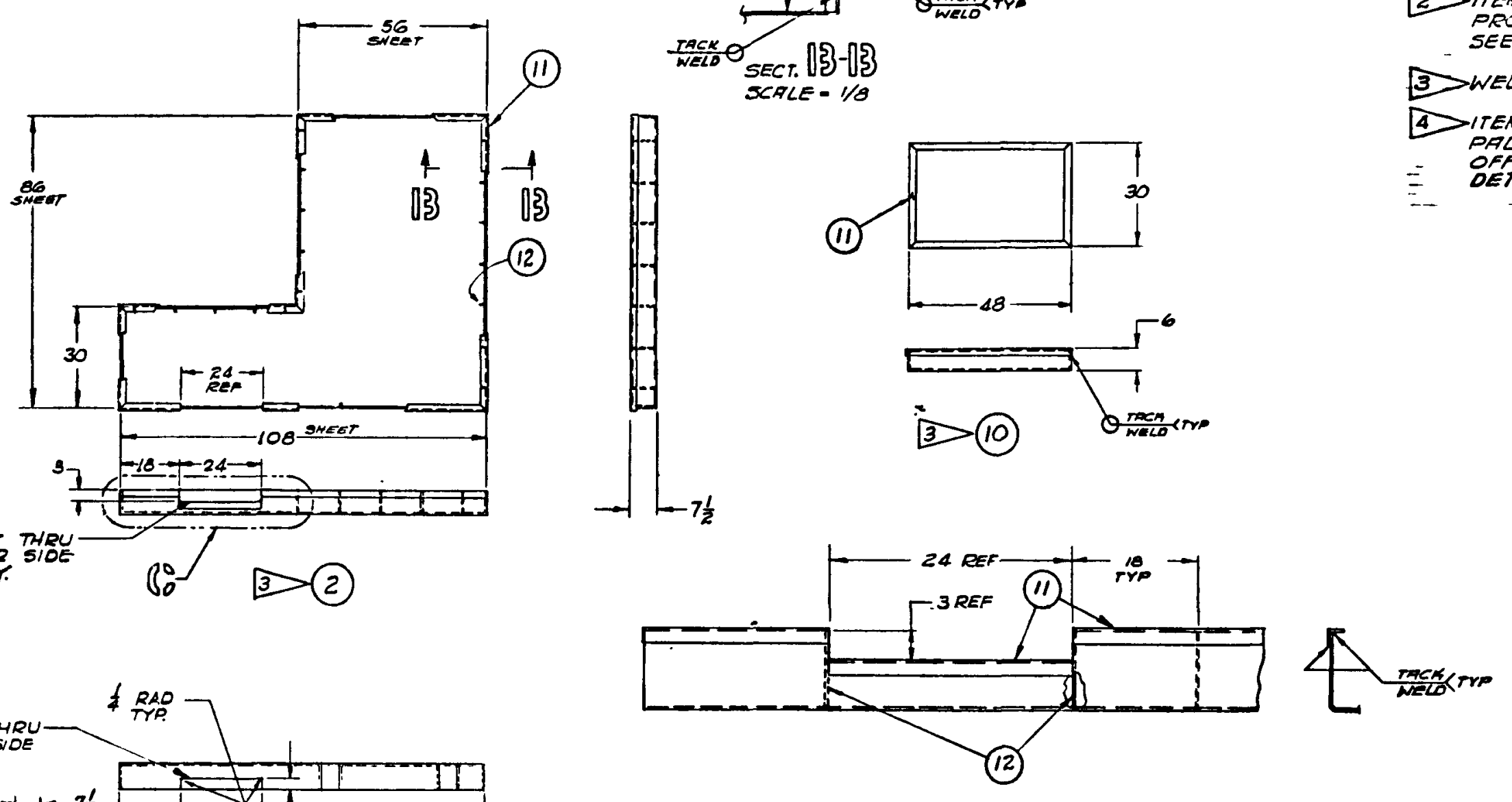

DET $6:$
NOTES:

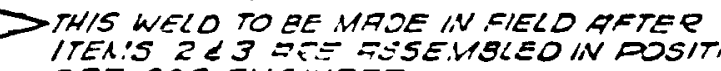
EOG ENGINEER

E TITEM 5 TO BE POSITIONED UNDER PREOULT RANA EN WEL

3 WELOED CONSTRUITION

4 ITEM $G$ TO REPLACE DRESENT FDOR

- OFE HERMATED IN FIELO, SEE COE ENGINEE

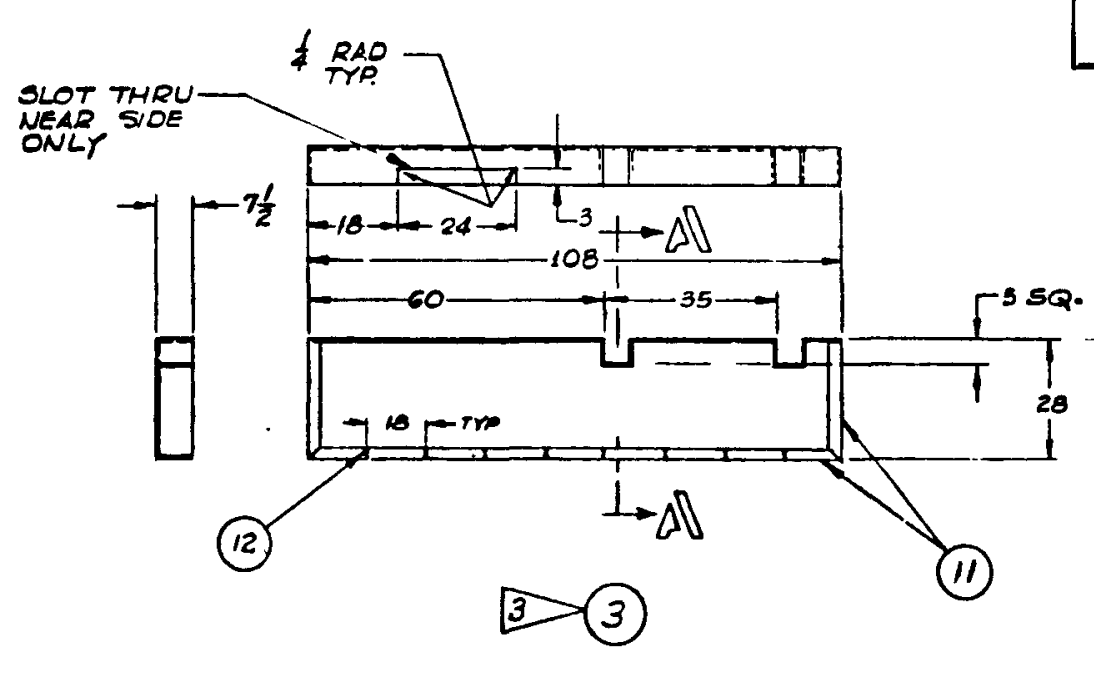


$\bullet$

-

$\bullet$

- 


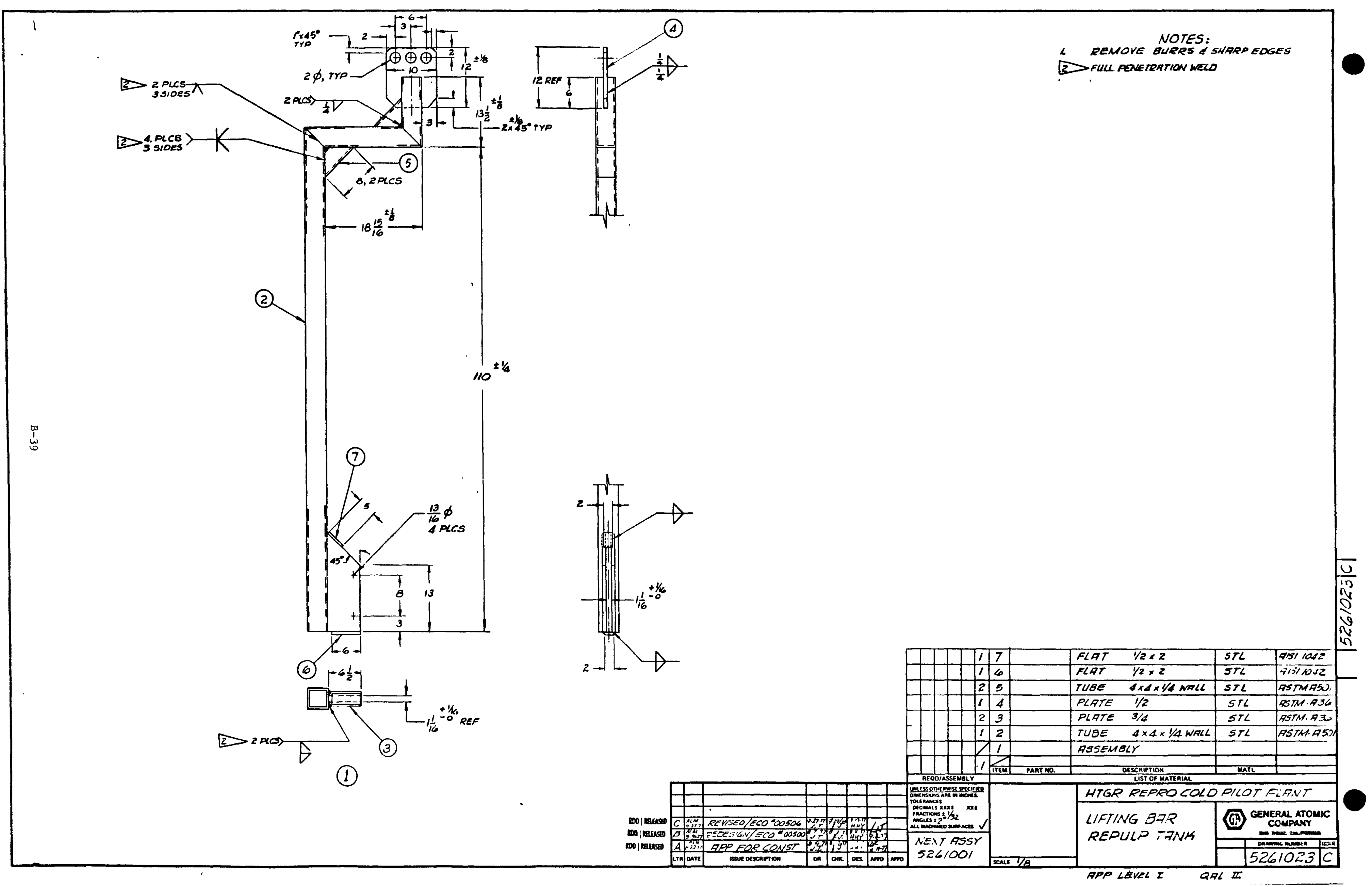


-

• $\quad \bullet$ 


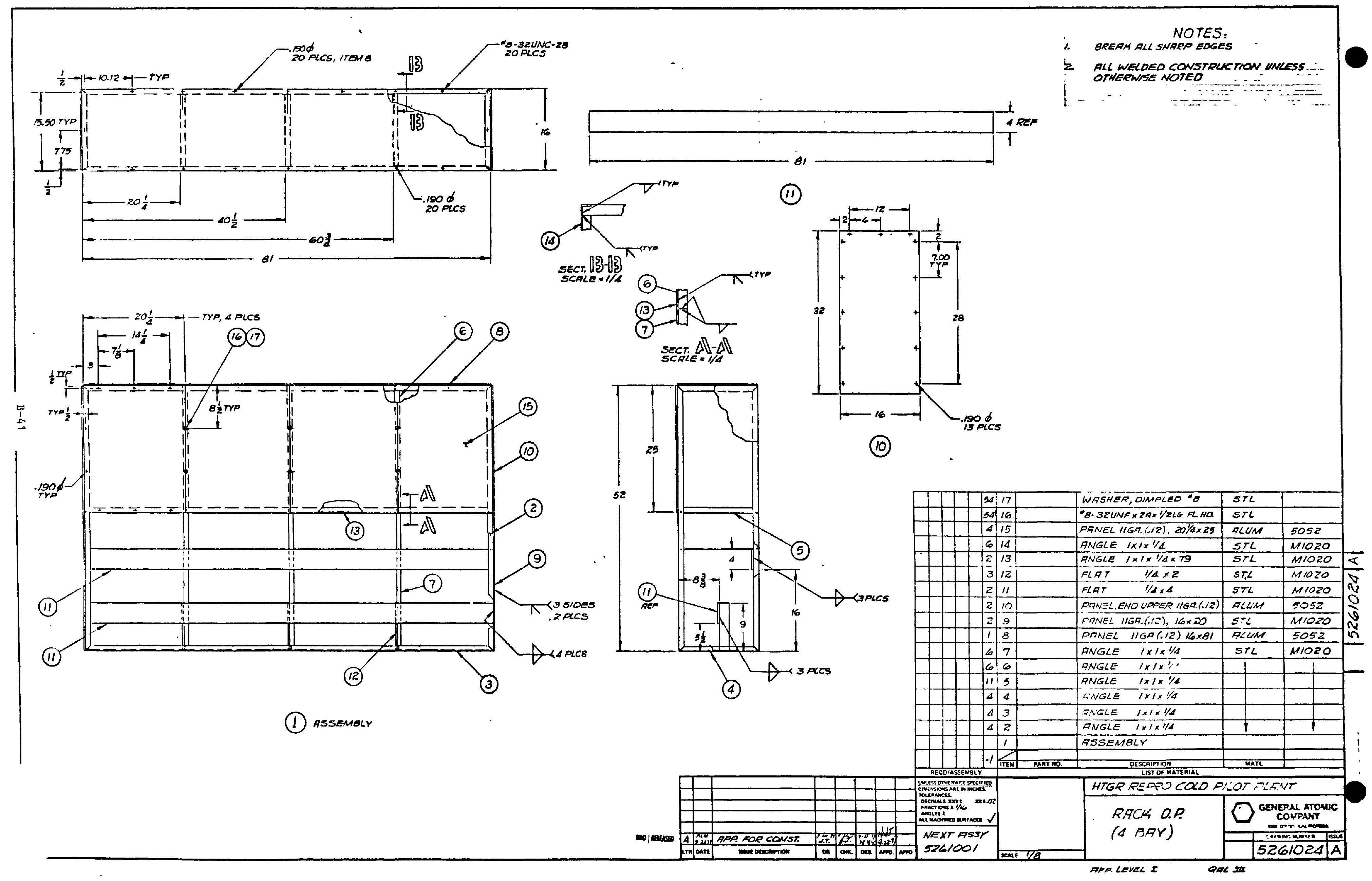

